\title{
ANGIOGENIC POTENTIAL OF HUMAN MACROPHAGES ON ELECTROSPUN BIORESORBABLE VASCULAR GRAFTS
}

Koyal Garg

Virginia Commonwealth University

Follow this and additional works at: https://scholarscompass.vcu.edu/etd

Part of the Biomedical Engineering and Bioengineering Commons

(C) The Author

\section{Downloaded from}

https://scholarscompass.vcu.edu/etd/1652

This Thesis is brought to you for free and open access by the Graduate School at VCU Scholars Compass. It has been accepted for inclusion in Theses and Dissertations by an authorized administrator of VCU Scholars Compass.

For more information, please contact libcompass@vcu.edu. 


\section{Virginia Commonwealth University}

This is to certify that the thesis prepared by Koyal Garg entitled Angiogenic Potential of Human Macrophages on Electrospun Bioreabsorbable Vascular Grafts has been approved by her committee as satisfactory completion of the thesis requirement for the degree of Master of Science in Biomedical Engineering.

Gary L. Bowlin, Ph.D., Director of Thesis, School of Engineering

David G. Simpson, Ph.D., School of Medicine

Hu Yang, Ph.D., School of Engineering

Gerald E. Miller, Ph.D., Chair of Biomedical Engineering, School of Engineering

Rosalyn S. Hobson, Ph.D., Associate Dean of Graduate Studies, School of Engineering

Russell D. Jamison, Ph.D., Dean, School of Engineering

F. Douglas Boudinot, Ph.D., Dean of the School of Graduate Studies

Date 
(C) Koyal Garg, 2008

All Rights Reserved 


\section{ANGIOGENIC POTENTIAL OF HUMAN MACROPHAGES ON ELECTROSPUN \\ BIORESORBABLE VASCULAR GRAFTS}

A thesis submitted in partial fulfillment of the requirements for the degree of Master of Science in Biomedical Engineering at Virginia Commonwealth University.

by

KOYAL GARG

B.E., Avinashilingam Deemed University, India, 2006

Director: GARY L. BOWLIN, PH.D.

ASSOCIATE PROFESSOR, BIOMEDICAL ENGINEERING

Virginia Commonwealth University

Richmond, Virginia

December, 2008 


\section{Acknowledgement}

I would like to start by thanking Dr. Bowlin, my advisor and mentor who gave me the opportunity to work in his lab. He has provided guidance and focus to both me and my research project. I am also thankful to his understanding, encouraging and appreciative attitude that kept me going. I have not worked closely with Dr. Simpson and Dr. Yang, but would like to thank you both for being on my committee and appreciate your support with my efforts to earn this Master's degree. I would also like to thank my lab members for putting up with my madness. Special thanks to Scott Sell and Parthasarathy Madurantakam, for patiently listening to me and providing me help and information. I learned a lot from both of you. Many thanks to Donna \& Matt Smith whose support and help got me started on ELISAs. I would also like to thank Josh Grant and Catherine Barnes for letting me shadow them. Thanks also go to my labmates, including Yas Maghdouri, Anna Bulysheva, Michael P. Francis, Michael McClure and Patricia Wolfe for making the lab a comfortable and fun place to work in. Last but not the least; I would like to thank the most vital part of life, my family. I can never thank my loving and caring parents enough for the endless support and guidance that they have given me all these years. My late grandmother deserves a big portion of my thanks. She has been a tremendous source of strength and will always be in my heart. To my younger brother, thank you for being my reason to smile. 


\section{Table of Contents}

Page

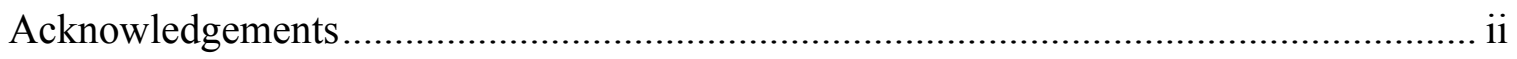

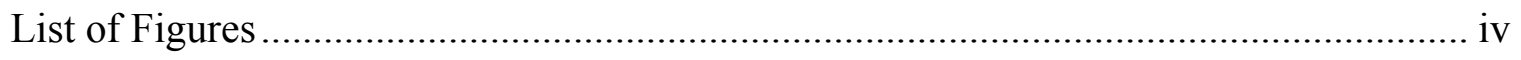

Chapter

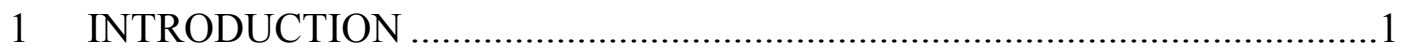

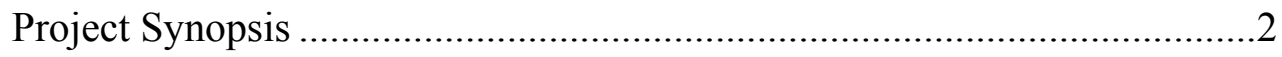

2 BACKGROUND INFORMATION ...........................................................

Blood Vessel Architecture...................................................................

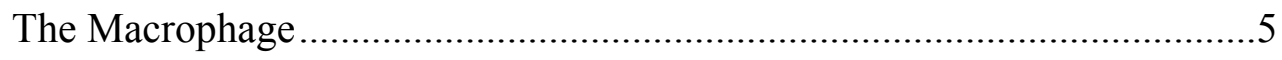

Macrophages and Angiogenesis ..................................................... 8

Vital Angiogenic Molecules................................................................. 10

Biomaterials for Vascular Tissue Engineering......................................12

Host Response to Biomaterials........................................................ 17

Electrospinning..............................................22

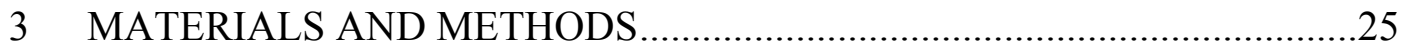

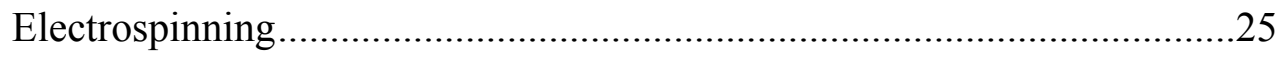

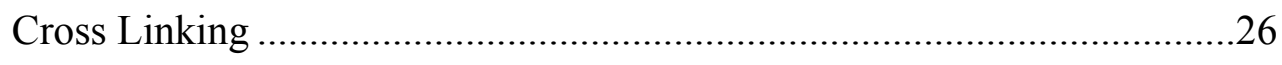

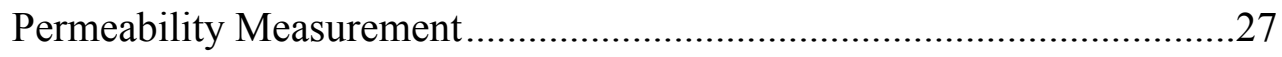

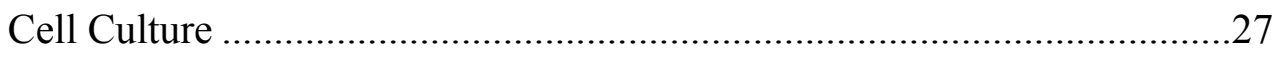




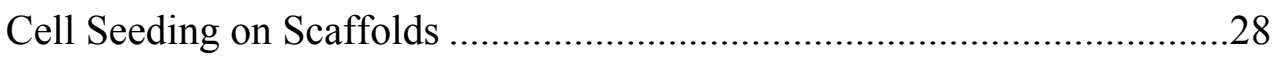

Enzyme Linked Immunosorbent Assay (ELISA) ...................................29

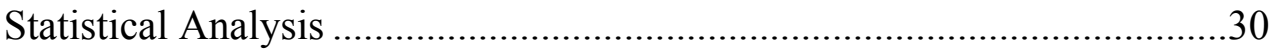

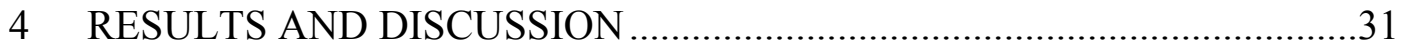

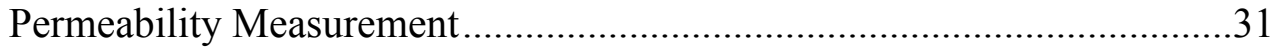

Macrophage Derived Chemokine ELISA ..............................................33

Macrophage Factor Secretion (Quantification by ELISA)........................34

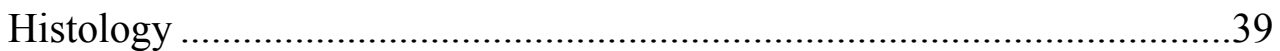

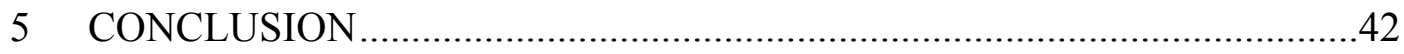

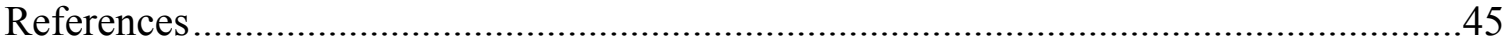

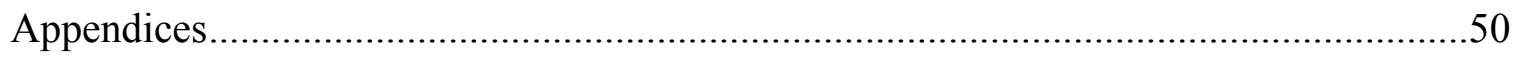

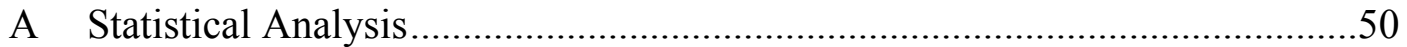




\section{$\underline{\text { List of Figures }}$}

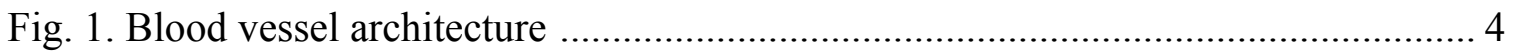

Fig. 2. The mononuclear-phagocyte system. …………............................................... 7

Fig. 3 Microenvironmental cues that affect angiogenesis. ............................................. 9

Fig. 4. Role of macrophages in angiogenesis ................................................................. 10

Fig. 5. Diagram showing macrophage response to biomaterials .................................... 20

Fig. 6. Foreign body reaction to an implanted synthetic biomaterial ............................ 21

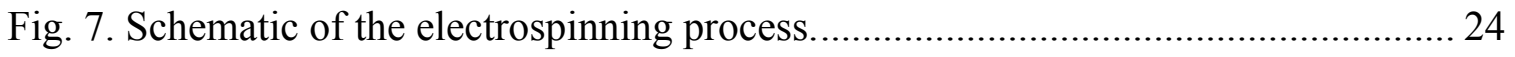

Fig. 8. Diagram of the permeability measurement device used in the study................... 27

Fig. 9. Permeability measurements for samples of electrospun PDO:elastin scaffolds. Error bars indicate standard error of the mean.............................................................. 32

Fig. 10. Permeability measurements for samples of electrospun PDO scaffolds of varying concentration. Error bars indicate standard error of the mean........................................ 32

Fig. 11. Quantification of MDC production by macrophages and monocytes. Error bars indicate standard error of the mean.

Fig. 12. Quantification of macrophage secretory activity on PDO:elastin scaffolds using ELISA. Error bars indicate standard error of the mean. Symbols ' $*$ ' and ' $\varnothing$ ' indicate a statistically significant difference from the control groups, media and TCP respectively $(\mathrm{p}<0.05)$

Fig. 13. Quantification of macrophage secretory activity on PDO scaffolds of varying concentrations using ELISA. Error bars indicate standard error of the mean. Symbols '*', and ' $\varnothing$ ' indicate a statistically significant difference from the control groups, media and TCP respectively $(\mathrm{p}<0.05)$. 
Fig. 14. Histology (H\&E) performed at day 21 (20x magnification)........................... 40

Fig. 15. Histology performed on various concentrations of PDO at day $21 \ldots \ldots \ldots \ldots \ldots \ldots . . . . . . . .41$ 


\begin{abstract}
ANGIOGENIC POTENTIAL OF HUMAN MACROPHAGES ON ELECTROSPUN

BIORESORBABLE VASCULAR GRAFTS
\end{abstract}

By KOYAL GARG, B.E.

A thesis submitted in partial fulfillment of the requirements for the degree of Master of Science in Biomedical Engineering at Virginia Commonwealth University.

Virginia Commonwealth University, 2008

Major Director: Dr. Gary L. Bowlin

Associate Professor, Biomedical Engineering

The aim of this study was to investigate macrophage interactions with electrospun scaffolds and quantify the expression of vital angiogenic growth factors in vitro. This study will further help in evaluating the potential of these electrospun constructs as vascular grafts for tissue repair and regeneration in situ. Human peripheral blood macrophages were seeded in serum free media on electrospun $(10 \mathrm{~mm})$ discs of polydioxanone (PDO), elastin 
and PDO:elastin blends (50:50, 70:30 and 90:10). The growth factor secretion was analyzed by ELISA. Macrophages produced high levels of vascular endothelial growth factor (VEGF) and acidic fibroblast growth factor (aFGF). Transforming growth factor beta-1 (TGF- $\beta 1$ ) secretion was relatively low and there was negligible production of basic fibroblast growth factor (bFGF). Histology revealed direct correlation between cell infiltration into scaffolds and the PDO concentration. There was greater macrophage infiltration through fibrous networks of the PDO and 90:10 scaffolds. Therefore, it can be anticipated that these scaffolds will support tissue regeneration and angiogenesis. 


\section{INTRODUCTION}

Macrophages are known to play a central role in implant healing, vascularization and integration into the native tissue. It has been established from previous studies that the fate of a tissue engineered implant depends upon the kind of macrophage response it elicits [1]. Tissue regeneration begins with phagocytosis of debris and extracellular matrix (ECM) remodeling and reorganization through enzymes released by the macrophage which include proteinase, collagenase, elastase and hyaluronidase [2]. The second step involves cell recruitment, migration, proliferation and ECM formation via the spectrum of cytokines produced by the macrophage. The third and final step of tissue regeneration is angiogenesis, a process by which new capillary blood vessels are generated from a preexisting vascular system. Angiogenesis is fundamental to wound healing, reproduction and embryonic development [2]. It results from stimulation of endothelial cells, which causes them to proliferate and migrate towards the source of pro-angiogenic molecules. On reaching a certain appropriate density, junctions between endothelial cells are formed, components of ECM are produced and a new basal membrane is formed [3]. The endothelial cells then progress to form a hollow tube. All steps in this transformation are induced by the myriad of growth factors derived from the macrophage. 


\section{Project Synopsis}

The aim of this study was to investigate macrophage interactions with electrospun scaffolds and quantify the expression of four vital angiogenic growth factors in vitro, vascular endothelial growth factor (VEGF), acidic fibroblast growth factor (aFGF), basic fibroblast growth factor (bFGF) and transforming growth factor beta-1 (TGF- $\beta 1$ ). This study will further help in evaluating the potential of these electrospun constructs as vascular grafts for tissue repair and regeneration in situ.

Polydioxanone (PDO) and elastin were dissolved in 1,1,1,3,3,3-hexafluoro-2propanol in concentrations of $100 \mathrm{mg} / \mathrm{ml}$ and $200 \mathrm{mg} / \mathrm{ml}$ respectively. These solutions were blended in the ratios of 50:50, 70:30 and 90:10 (PDO:elastin) by volume. Pure PDO (100:0) and pure elastin (0:100) were also used in the study. These were then electrospun into a flat sheet.

Human peripheral blood monocytes (CRL9855, ATCC) were seeded into culture at a density of $6 \times 10^{7}$ cells per $75 \mathrm{~cm}^{2}$ flask in Dulbecco's modified eagle medium (high glucose) with $20 \%$ heat inactivated fetal bovine serum and $10 \%$ heat inactivated $\mathrm{AB}+$ serum. This cell concentration provided a high seeding density for differentiation of monocytes to macrophages. Macrophages were obtained after 21 days of culture. The macrophages were then seeded at a density of 400,000 cells/well on electrospun $(10 \mathrm{~mm})$ disks of PDO, elastin, PDO:elastin blends (50:50, 70:30 and 90:10) and on tissue culture plastic (TCP) in a 48 well plate. The supernatants were collected on day 7, 14, 21 and 28 and stored at $-70^{\circ} \mathrm{C}$ until analyzed by ELISA. 


\section{BACKGROUND INFORMATION}

\section{Blood Vessel Architecture}

The complex blood vessel system of the human body serves two main functions, delivery of oxygen and nutrients to the tissues and removal of metabolites for clearance or re-oxygenation. As shown in figure 1, the artery is composed of three different layers or tunics of different compositions which surround a hollow core or lumen through which the blood flows. The innermost layer, surrounding the lumen is known as the intima and is made up of single layer of endothelial cells on a basement membrane rich in collagen IV and elastin. This layer contacts the bloodstream and endothelial cells provide a crucial barrier to platelet activation by secreting specific molecules like nitric oxide and prevent thrombus formation. The thick middle layer, the media, is composed of several layers of smooth muscle cells in an extracellular matrix of collagen types I and III, elastin and proteoglycans. In elastic arteries like the aorta, the elastic lamellae allow the artery to maintain sufficient blood pressure with variations in hemodynamic stress of the cardiac systole and diastole. In muscular arteries, elastin is assembled as fibers. The outermost adventitial layer is composed of fibroblasts and randomly arranged collagen type I. This, collagen provides tensile support and prevents vessel rupture. The proteoglycans contribute 
to the compressibility and the elastin fibers give elasticity to the vessel and provide the ability to recover from pulsatile deformations. Its elastic nature dominates the low strain mechanical response of the vessel to blood flow and prevents pulsatile energy from being dissipated as heat $[4,5]$.
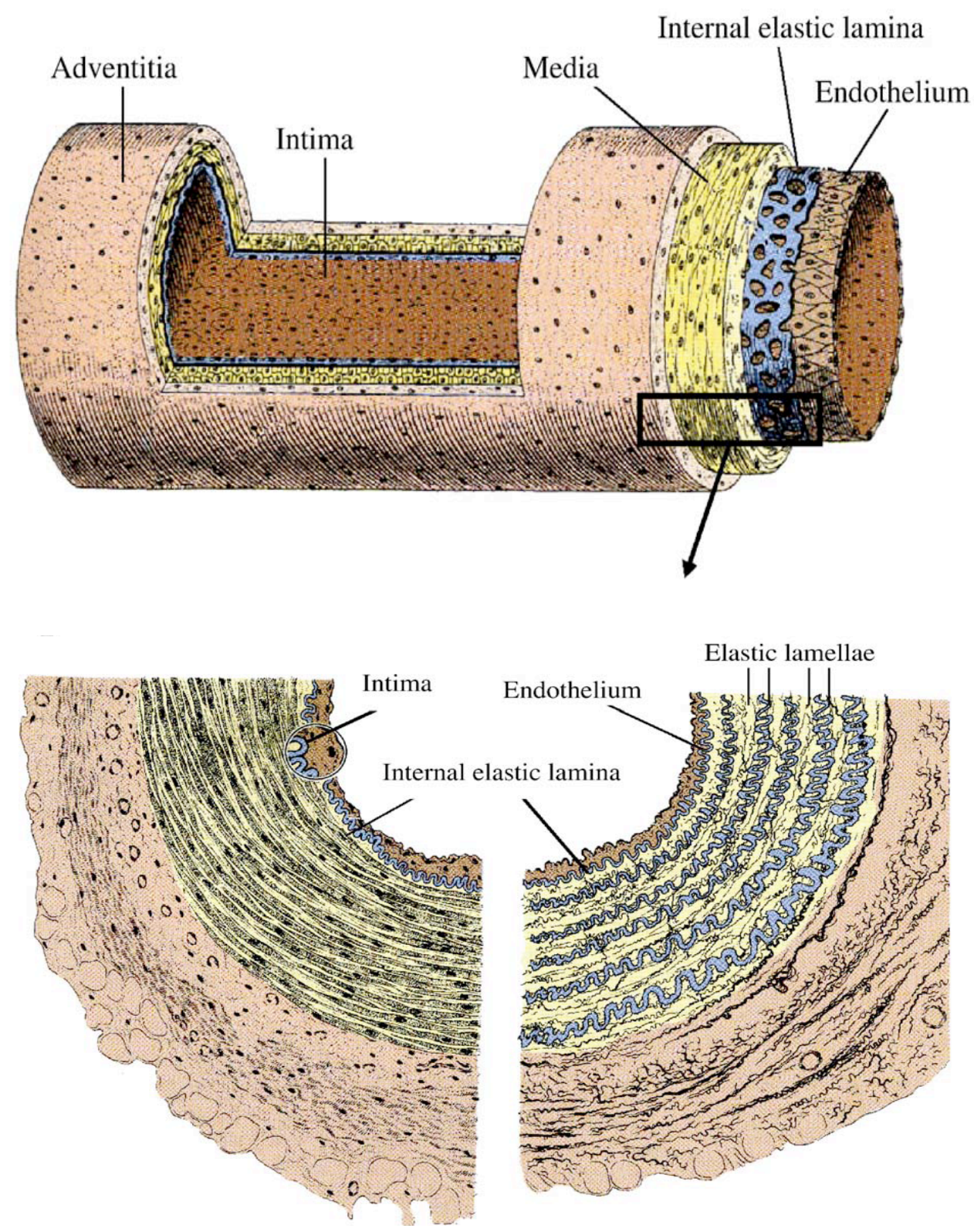

Fig. 1. Blood vessel architecture [6]. 


\section{The Macrophage}

Macrophages belong to the mononuclear phagocyte system. This system comprises the bone marrow monoblasts, pro-monocytes, peripheral blood monocytes and tissue macrophages. They share a common progenitor cell with granulocytes in the bone marrow. This common progenitor is called the colony-forming unit, granulocyte-macrophage (CFU-GM) because of its ability to give rise to colonies of monocytes and neutrophils in a semi-solid marrow cultures. When monocytes enter the blood stream and migrate into tissues, they undergo final differentiation to tissue macrophages (Fig.2). Macrophages are present ubiquitously in all tissues and display great structural and functional heterogeneity as histiocytes, alveolar macrophages (lungs), kupffer cells (liver), osteoclasts (bone), peritoneal macrophages (peritoneum), synovia type A cells (synovium), or microglia (central nervous system). Macrophages are set into different functional states by a process known as activation. Activation of macrophages entails increased phagocytic or microbicidal activities and alteration of their chemotactic response and secretory activities. Activation is a complex process involving different stimuli. Macrophages increase performance of some functions and down regulate others. Some of the listed activators in literature are concanavalin A, endotoxin, lipopolysacchride and various cytokines such as interferon- $\gamma($ IFN- $\gamma$ ), granulocyte-macrophage colony stimulating factor (GM-CSF), platelet-activating factor (PAF) or monocyte chemotactic protein $[7,8]$. 
Macrophages also secrete a repertoire of proteases and growth factors such as bFGF, GMCSF, transforming growth factor- alpha (TGF- $\alpha)$, TGF- $\beta$, Insulin-like growth factor-I (IGF-I), Platelet-derived growth factor (PDGF), VEGF, and other monokines such as inerleukins (IL-1, IL-6, IL-8), tumor necrosis factor-alpha (TNF- $\alpha$ ), substance P, prostaglandins, interferons, thrombospondin 1 [7]. 


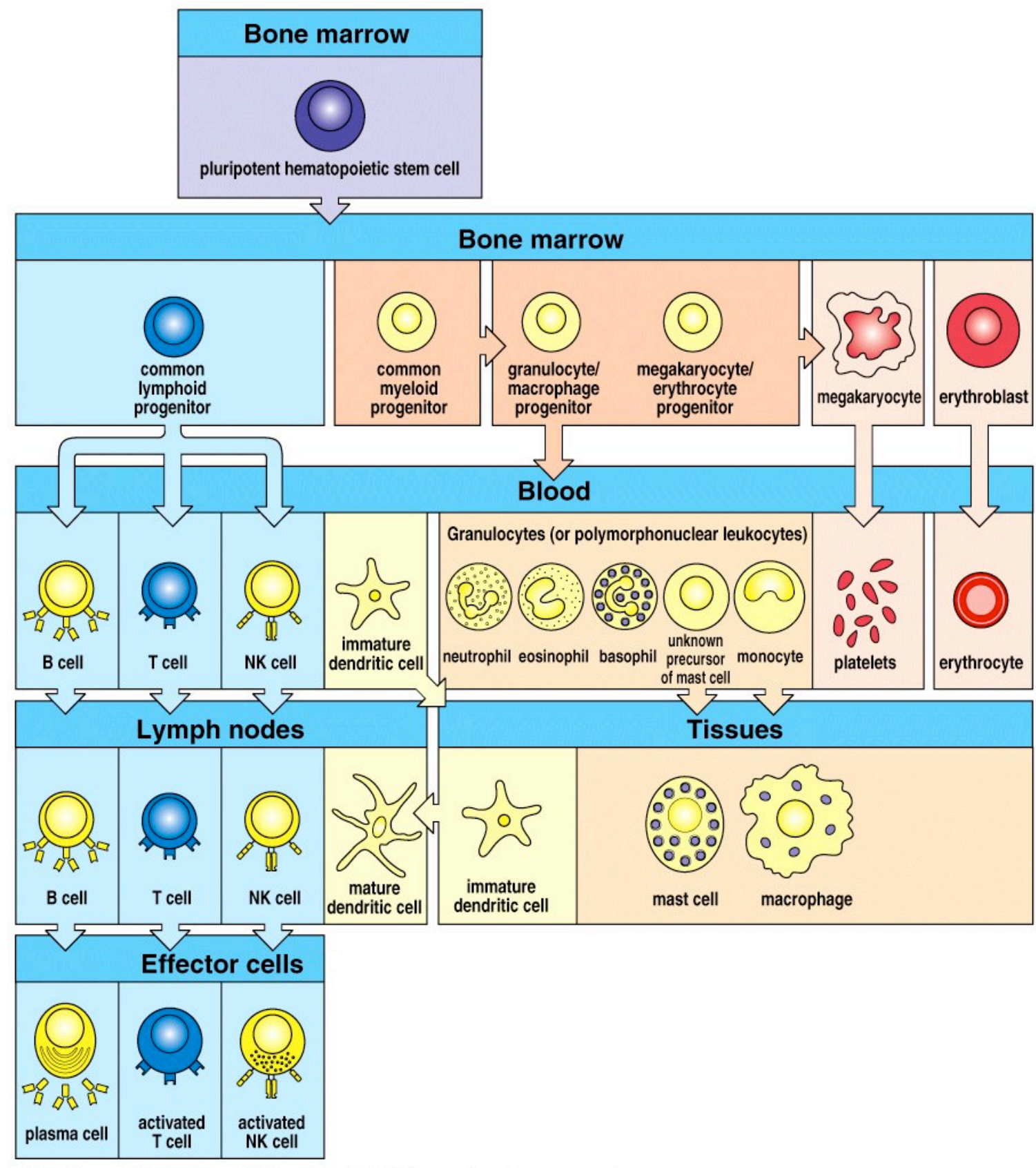

Fig. 2. The mononuclear-phagocyte system [9]. 


\section{Macrophages and Angiogenesis}

The macrophage is the major differentiated cell of the mononuclear phagocyte system. It originates in the bone marrow as an immature monocyte. After entering the peripheral blood, monocytes are recruited by chemokines into the tissue and undergo differentiation into macrophages. The specialization and activation of these cells are mainly influenced by local stimuli $[10,11]$. Angiogenesis is a multi-step process involving various cell types. It is tightly regulated by several microenvironmental factors in the blood vessel, including soluble molecules (e.g., growth factors and cytokines), extracellular matrices (ECM), interactions between adjacent endothelial cells (ECs) and ECs with other cell types, as well as mechanical forces originating from ECs themselves, blood flow, and extravascular tissue activity (Fig.3).

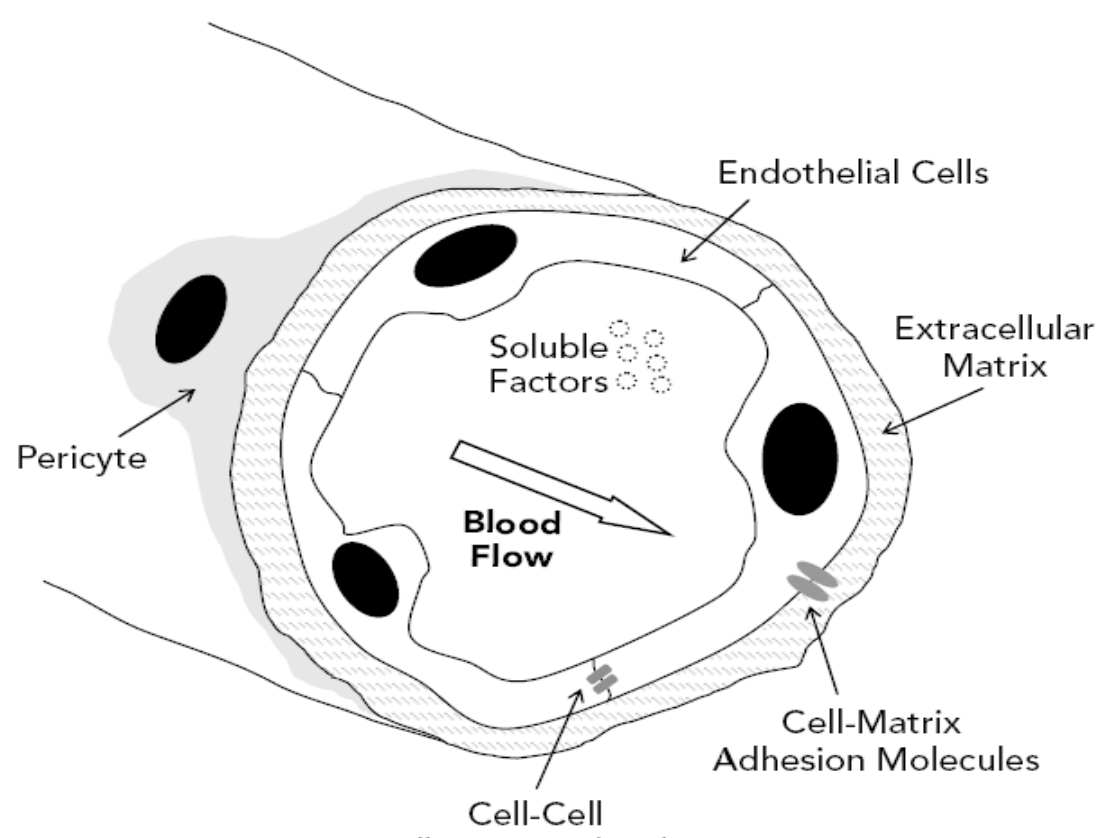

Adhesion Molecules 
Fig.3 Microenvironmental cues that affect angiogenesis [12].

The outstanding role of macrophages in angiogenesis can be attributed to their much longer half life as compared to granulocytes and platelets and secretion of myriad of growth factors for initiation, maintenance and termination of the angiogenic process (Fig.4). Also, macrophages are resident in all tissues in greater numbers than other blood borne cells and the distinct subtypes can always be recruited from the blood stream. They have heterogeneous functionality and can be activated from an inactive non-angiogenic stage to an angiogenic stage [7]. Growth factors are released by macrophages only when they are activated. The authors speculate that the macrophages will get activated when they come in contact with the biomaterials [13]. There are two known phenotypes of macrophage activation. Classically activated macrophages up regulate pro-inflammatory cytokines, inhibit anti-inflammatory cytokines and fibrogenesis. On the other hand, alternatively activated macrophages inhibit pro-inflammatory cytokines, promote antiinflammatory cytokines and enhance fibrogenesis. The biomaterial adherent macrophage phenotype is known to have a different cytokine profile than either classically or alternatively activated macrophages indicating that the biomaterial activation is unique. Macrophage activation and cytokine expression can be modulated by the material properties, such as surface chemistry and surface topography [14]. 


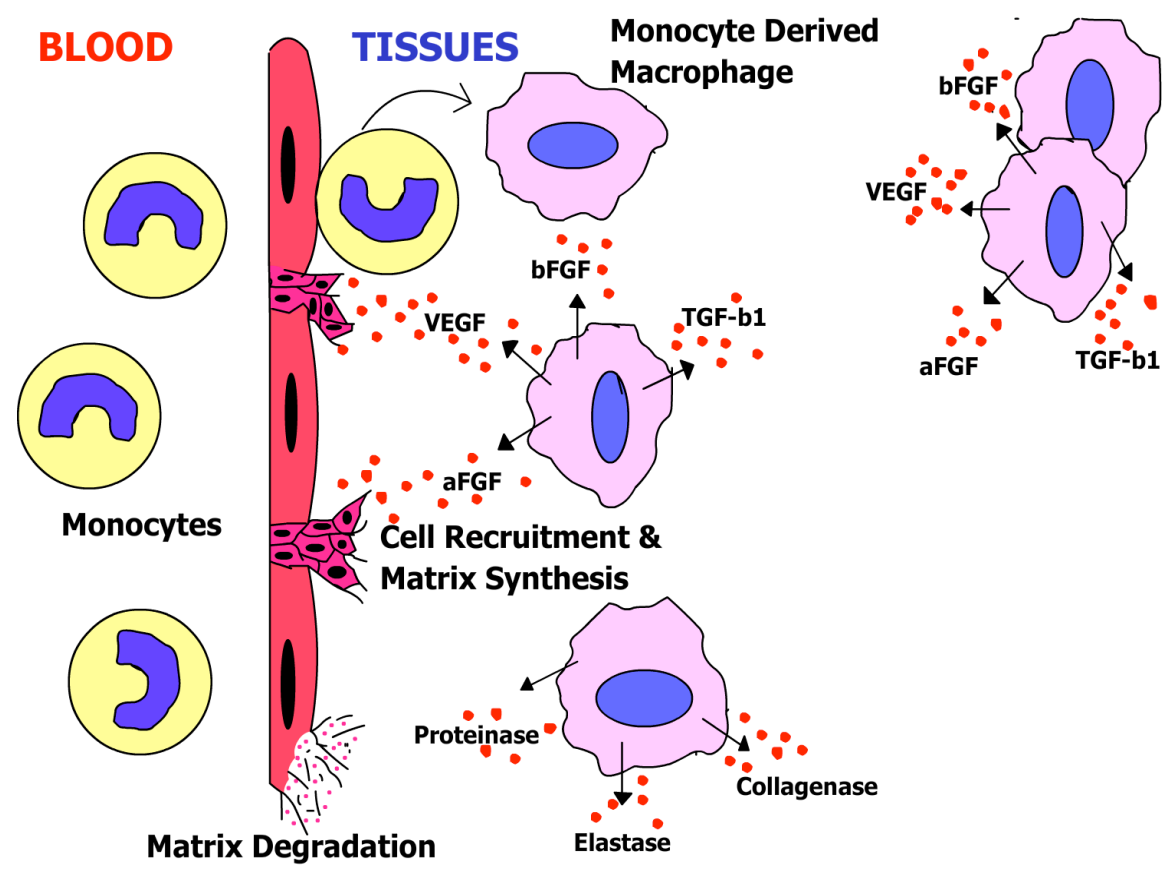

Fig. 4. Role of macrophages in angiogenesis.

\section{Vital Angiogenic Molecules}

The molecule VEGF (previously known as Vascular Permeability Factor) is by far the most potent angiogenic growth factor known. It is secreted in biologically active form by activated peripheral blood monocytes/macrophages. Besides directly stimulating angiogenesis, it also helps in regulating the production of proteases and their inhibitors, and promotes endothelial cell proliferation, migration, differentiation and survival [1]. VEGF induces vascular dilation and exudation of fibrin. The deposition of fibrin induces monocyte migration, penetration and tunnel formation in this new ECM [12]. bFGF and 
aFGF belong to a family of heparin binding (fibroblast) growth factors and can promote almost every phase of the angiogenesis cascade. They both induce urokinase-type plasminogen activator (uPA) in different cell types [3] . Secreted uPA converts plasminogen into plasmin, a protease which degrades ECM proteins and activates other metalloproteinases (MMPs) necessary for further degradation and remodeling of ECM . It also stimulates proliferation, DNA synthesis and migration of endothelial cells towards the place where new blood supply is needed [3] . Unlike VEGF, the actions of bFGF and aFGF are not limited to ECs. They act on most cells derived from mesoderm and ectoderm such as fibroblasts, pericytes and ECs.

TGF- $\beta 1$ has both stimulatory and inhibitory effects on angiogenesis. It stimulates in vivo angiogenesis in presence of inflammatory response but is an inhibitor of endothelial cell growth in vitro $[12,15]$. Actions of TGF- $\beta 1$ depend upon its concentration and ECM organization. Higher concentration and two dimensional culture systems inhibited the migration and proliferation of endothelial cells whereas low concentration and three dimensional culture systems supported the proliferation and tube formation of endothelial cells [7]. It was also found that TGF- $\beta 1$ mediates the inhibition of endothelial cell proliferation upon endothelial cell-pericyte contact in a coculture system. These effects are critical in stabilizing nascent, immature blood vessels [12]. Over expression of this cytokine results in fibrotic conditions since it promotes accumulation of ECM molecules $[15]$. 
Tissue macrophages also express Angiopoietin-1 (Ang-1). It binds to the Tie-2 receptor and potently induces network formation, chemotactic response and survival during apoptosis. It also stabilizes nascent vessels by tightening the interaction between endothelial and periendothelial cells. It also causes sprouting of endothelial cells in fibrin gel but does not stimulate proliferation. As an antagonist of Ang-1, Angiopoietin-2 (Ang2) competes with Ang-1 for binding of Tie-2 and blocks vessel stabilization from Tie-2 signaling. It thus loosens the interactions of ECs with pericytes and the ECM leading to vessel destabilization. Many different cell types, including ECs, fibroblasts, macrophages and platelets release a molecule called platelet-derived growth factor (PDGF). In blood vessel walls, PDGF receptors can be found in smooth muscle cells (SMCs), ECs and pericytes. In vivo studies have demonstrated that proliferation and migration of pericytes along angiogenic sprouts is mediated by PDGF [12].

\section{Biomaterials for Vascular Tissue Engineering}

The ideal vascular prosthetic must have the following performance characteristics: ease of handling, suture retention, ease of suture replacement, flexibility with kink resistance, biocompatibility, durability after implanatation and association with surrounding connective tissue, compliance matching that of the native artery, and resistance to aneurysm formation. Also, the graft must be easily manufactured, economical, easily stored and available in a variety of sizes [16]. 
Initial graft research focused on Poly(ehtylene terephthalate) (Dacron) and expanded poly(tetrafluoroethylene) (e-PTFE) as prosthetic vascular grafts. Both Dacron and e-PTFE react with blood components and perigraft tissues in both advantageous and injurious ways. It has been documented that monocytes and macrophages produce cytokines such as interleukin 1 beta (IL-1 $\beta$ ), interleukin 6 (IL-6), and tumor necrosis factor alpha (TNF- $\alpha)$ when incubated with Dacron and e-PTFE [17].

However, these prostheses remained permanently within the host after implantation. The concept of a slowly absorbable graft that could stimulate rapid and controlled regenerative process producing a "neoartery" was first described by Wesolowski et al. [18] and Ruderman et al. [19]. These grafts were partially bioresorbable and composed of Dacron and polylactide yarns. Bowland et al. described the use of Vicryl (a copolymer of polyglycolide and polylactide) as a fully bioresorbable vascular graft [20]. These early grafts were susceptible to aneurismal rupture and dilation.

Greisler et al. evaluated woven poly(glycolic acid) (PGA) grafts in a rabbit model. Four weeks after implantation, these grafts were shown to contain an inner capsule composed of a confluent layer of endothelial cells and smooth muscle like myofibroblasts in the midst of dense collagen fibers. Similarly constructed and implanted Dacron grafts failed to show the results described above $[21,22]$.

It is also important for the bioresorbable graft to regenerate a complex tissue of sufficient strength before prosthetic degradation so as to minimize the risk of aneurismal dilation. To circumvent this problem two or more bioresorbable materials with different 
resorption rates can be combined so that the more rapidly absorbed material induces rapid tissue ingrowth while the second material provides structural support [23]. Such composite grafts containing 69\% polyglactin 910 (PG910) and 31\% polypropylene were implanted into rabbit and dog arteries [24]. These grafts demonstrated 100\% 1-year patency with no aneurysms. In another study, composite grafts of 74\% PG910 and 26\% polydioxanone (PDO/PDS) also showed 100\% patency with no aneurysms one year after implantation [25]. PDO is a colorless, crystalline, biodegradable polymer that was developed for wound closure sutures. It exhibits high flexibility, higher strength retention, slower absorption rate, and lower inflammatory response as compared to poly(glycolide lactide) and poly(glycolic acid) [16]. Greisler et al. published results utilizing PDO absorbable vascular prosthetics in a rabbit aortic model of regeneration. The results showed no perigraft hematomas and the myofibroblast migration paralleled the macrophage-mediated degradation of the PDO structure. A confluent EC lining was present within two weeks, with the compliance of the explants at 1 year resembling an artery [26]. In another study, Geisler et al. demonstrated that PDO grafts had the highest production ratio of $\mathrm{PGI}_{2} / \mathrm{TxA}_{2}$ at a seven fold increase versus PGA and approximately equal to the native aorta control. The study showed a tissue dependence response in terms of thrombogenicity and the grafts containing PDO were less thrombogenic [27].

Recent advances in tissue engineering have shifted focus on synthetic and natural blends of polymers for use as vascular grafts. The introduction of natural polymer increases the hydrophilicity and cellular affinity of the material. This in turn enhances the 
cell attachment, migration and proliferation. The natural polymer invariably degrades first, creating more space for cell migration and tissue regeneration while the synthetic polymer maintains the structural integrity. Zhang et al. created gelatin and PCL electrospun blends that exhibited enhanced mechanical properties and better wettability than that obtained from PCL or gelatin alone [28]. A mixture of heparin and poly (ethylene glycol) (PEG) was electrospun for potential use as a wound dressing. The presence of PEG slowed down the release of heparin and permitted better biological outcomes [29]. Boland et al. demonstrated the electrospinning of a blend of collagen and elastin for use as vascular tissue engineered constructs [30].

In elastic tissues, polymers of elastin confer elasticity to the vessel and provide the ability to recover from pulsatile deformations [30]. Elastin is an abundant protein component of the native arterial tissue and is chosen to confer elasticity and bioactivity to the vascular prosthetic [5]. In arteries, elastin dictates tissue mechanics at low strains before stiffer collagen fibers are engaged. Elastin also prevents dynamic tissue creep by stretching under load and recoiling to their original configurations after the load is released. It is also a strong autocrine regulator of vascular smooth cells activity and this is crucial for prevention of fibrocellular pathology. Elastin induces actin stress fiber organization, inhibits smooth muscle cell proliferation, and regulates migration via a nonintegrin heterotrimeric $\mathrm{G}$ protein coupled signaling pathway. In the absence of extracellular elastin, smooth muscle cell proliferation stenoses arteries. Therefore, in order to ensure 
proper mechanical function of the vessel and to prevent vessel stenosis, tissue engineered vascular implants must include an elastic component [6].

In the field of vascular tissue engineering and vascular prosthetic it is important to match or mimic the mechanical properties of the native tissue to eliminate mismatches between the prosthetic and the native tissue. Previous studies conducted on PDO: elastin blends have shown a range of mechanical properties that included those of native arterial tissue. The mechanical properties of the 50:50 blend closely matched the range of femoral artery values in almost every instance, the only exception being that the electrospun 50:50 blend exhibited higher ultimate stresses than the native vessel. Compliance is another important property of the blood vessels that assists in pushing blood through the circulation and prevents flow stagnation and graft thrombosis. It was found that the grafts containing elastin had greater compliance than pure PDO grafts [5].

The biomaterials chosen for this study were PDO blended with elastin in three ratios $(50: 50,70: 30,90: 10)$ to create nanofibrous, seamless tubular constructs for potential use as acellular vascular prosthetics [5]. This study will further help in evaluating the capability of this vascular prosthetic to promote in situ arterial tissue regeneration. To evaluate the effect of fiber diameter on macrophage interactions with biomaterials, different concentration of PDO $(60,80,100,120,140 \mathrm{mg} / \mathrm{ml})$ were also electrospun and tested. The process used for the fabrication of this construct is electrospinning. Briefly, it consists of a charged polymer solution separated from an oppositely charged target by a set distance (air gap) to create a static electric field. When the electrostatic forces within the 
solution overcome the surface tension of the solution, a fine jet of entangled polymer chains is drawn out. The solvent evaporates as the jet travels through the air gap, and a dry fiber is collected on the target. The translation/rotation of the target ensures uniformity in structural characteristics [5].

The growth factors are released by macrophages only when they are activated. The authors speculate that the macrophages will be activated when they come in contact with the biomaterials. Macrophage activation through stimulation by lipopolysaccharide (LPS) or concanavalin A has been done in previous studies. It has been observed that the presence of such agents not only proportionately increase all the growth factor levels, but also manipulate the types being expressed leading to misinterpretation of the data. Therefore, in these studies we refrained from using stimulating agents to assess the growth factor production [31].

\section{Host Response to Biomaterials}

Following tissue injury, the normal healing response is initiated through a series of intricate events that include acute inflammation, the formation of granulation tissue, and eventual scar formation. The immediate response is to deluge the injured area with blood. Cleavage of fibrinogen within the blood into fibrin is done to form a blood clot that promotes platelet adhesion and aggregation. A spectrum of cytokines and growth factors are released to recruit white blood cells, primarily neutrophils. Monocytes are then 
recruited to the wound site where they differentiate into macrophages. The macrophages are responsible for cleaning up the wound site, by phagocytosis of debris which may include foreign material, bacteria, necrotic and apoptotic cells. In addition, they are also required for recruiting cells such as fibroblasts and endothelial cells. These cells convert the fibrin clot into a highly vascularized granulation tissue. The formation of blood vessels is crucial to the healing wound. Fibroblasts subsequently replace the granulation tissue by an extracellular matrix (ECM). The degree of ECM remodeling is dependant on the extent and location of the injury. It has been observed that in some cases, complete restoration of the tissue architecture is possible but mostly granulation tissue is remodeled into scar tissue.

When a biomaterial is implanted into the body it induces a different response, termed the foreign body reaction (Fig.5 and 6). Briefly, a biomaterial elicits nonspecific protein adsorption immediately upon implantation. Many different proteins adsorb to the surface in a range of conformations from native to denatured. However, non-specific protein adsorption has never been observed in the normal physiological process of wound healing. Thus, nonspecific protein adsorption is believed to be an instigator in the foreign body reaction. A variety of cells, that are key players in normal wound healing (such as monocytes, leukocytes, and platelets) adhere to these biomaterial surfaces and as a result may lead to upregulation of cytokines and subsequent proinflammatory mechanisms. 
Macrophage response to biomaterials is dependent on the size of the materials. Material particle sizes smaller than a single-nucleated macrophage (normally around 10 $\mu \mathrm{m}$ in diameter) can be phagocytozed by macrophages. Large particles (between $10 \mu \mathrm{m}$ and several hundred micrometres) that are beyond the capacity of macrophage phagocytosis may be engulfed by multinucleated giant cells or foreign body giant cells [2]. Since the implant is significantly larger than the adhered macrophages, it prevents them from phagocytosing the foreign body. This initiates the chronic inflammation at the biomaterial interface and is followed by the fusion of the frustrated macrophages to form multinucleated foreign body giant cells that often persist for the lifetime of the implant. The resolution of macrophage responses to biomaterials depends on whether the material is degradable or nondegradable. Degradable materials are usually degraded by phagocytosis, or eroded via extracellular resorption, with or without the involvement of foreign body giant cells. Any associated inflammation is taken care of after total resorption of the biodegradable materials. Nondegradable materials cannot be degraded either within the macrophage phagosome, or by extracellular resorption. Macrophages infiltrate constantly to phagocytoze undigested particles or to fuse into foreign body giant cells and persist on the surface of the implanted materials. Therefore, for non-degradable biomaterials, it is vital to choose those that cause less macrophage responses for long-term implantation.

In the final stage of the foreign body reaction, the device is covered by an avascular, collagenous fibrous tissue that is usually 50-200 $\mu \mathrm{m}$ thick $[32,33]$. 


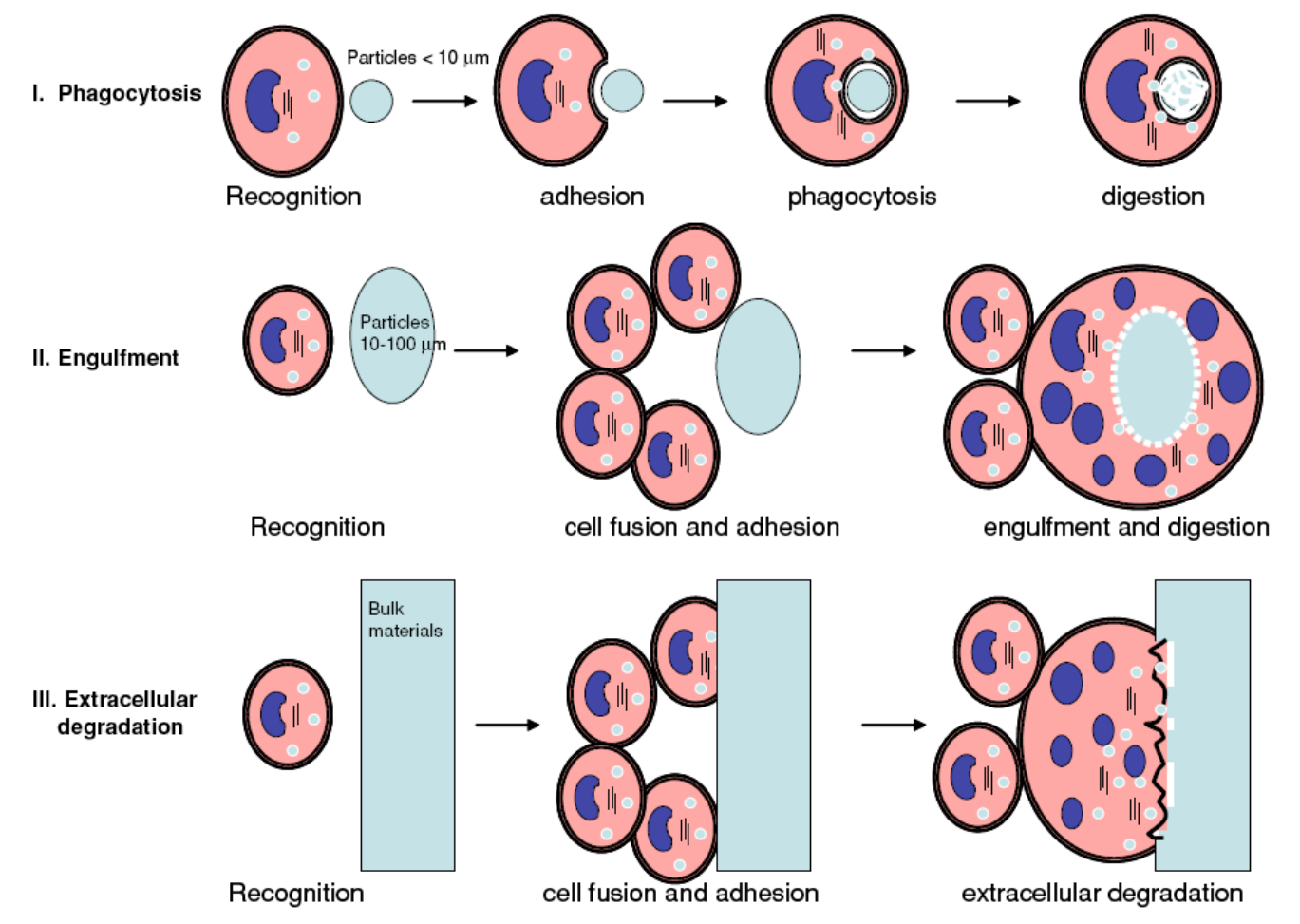

Fig. 5. Diagram showing macrophage response to biomaterials [2]. 


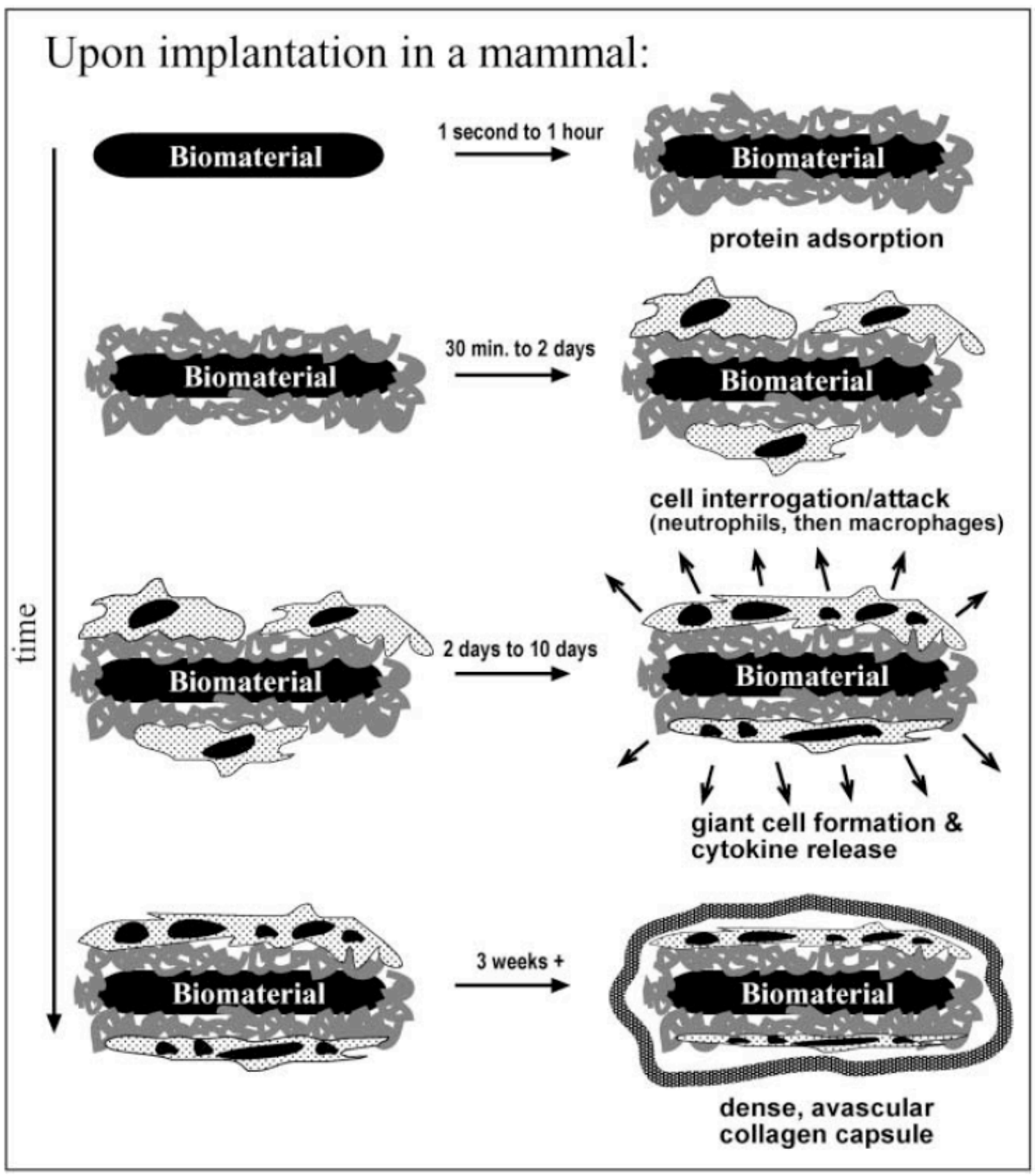

Fig. 6. Foreign body reaction to an implanted synthetic biomaterial [33]. 


\section{Electrospinning}

A number of processing techniques such as drawing, template synthesis, phase separation, self assembly and electrospinning have been utilized to synthesize polymer nanofibers for tissue engineering. Drawing is a process that can make one-by-one very long single nanofibers. However, only a viscoelastic material that can undergo very strong deformations can be made into nanofibers through drawing. Template synthesis, uses a nanoporous membrane as a template to make nanofibers of a solid or hollow shape. A major drawback of the method is the inability to synthesize one-by-one continuous nanofibers. The phase separation method consists of dissolution, gelation, extraction using a different solvent, followed by freezing and drying. In self assembly procedure, preexisting, individual components organize themselves into desired patterns and functions. However, both phase separation and self assembly processes are very time consuming in processing continuous polymer nanofibers. Electrospinning is an advantageous processing method for synthesizing one-by-one continuous nanofibers from various different polymers [34]. It's also a very simple, straight forward, cost-effective method to generate different types of scaffolds. Briefly, it consists of a charged polymer solution separated from an oppositely charged target by a set distance (air gap) to create a static electric field (Fig.7). When the electrostatic forces within the solution overcome the surface tension of the solution, a fine jet of entangled polymer chains is drawn out. The solvent evaporates as 
the jet travels through the air gap, and a dry fiber is collected on the target. The translation/rotation of the target ensures uniformity in structural characteristics [5] . There are great advantages of using electrospinning for tissue engineering applications. Electrospinning is capable of producing extremely thin fibers with diameters ranging from microns down to few nanometers. In native tissues, cells are typically about one to two orders of magnitude bigger than the structural ECM proteins $(50-300 \mathrm{~nm})$. This allows the cells to be in direct contact with many ECM fibers. Therefore, the small-size fibers mimic the structural dimension of the ECM of several native tissues which are deposited and characterized by well-organized hierarchical fibrous structures realigning from nanometer to millimeter scale. The scaffolds produced by electrospinning possess a highly porous microstructure with interconnected pores and extremely high surface-area-to-volume ratio, which is conducive to tissue growth. In addition, it is a very versatile technique and allows the use of a variety of polymers, blends of different polymers, and inorganic materials. Recent advances in electrospinning have shown that integration of various substances such as additives, biomolecules, and living cells is possible in scaffolds for tailoring different application requirements [28]. 


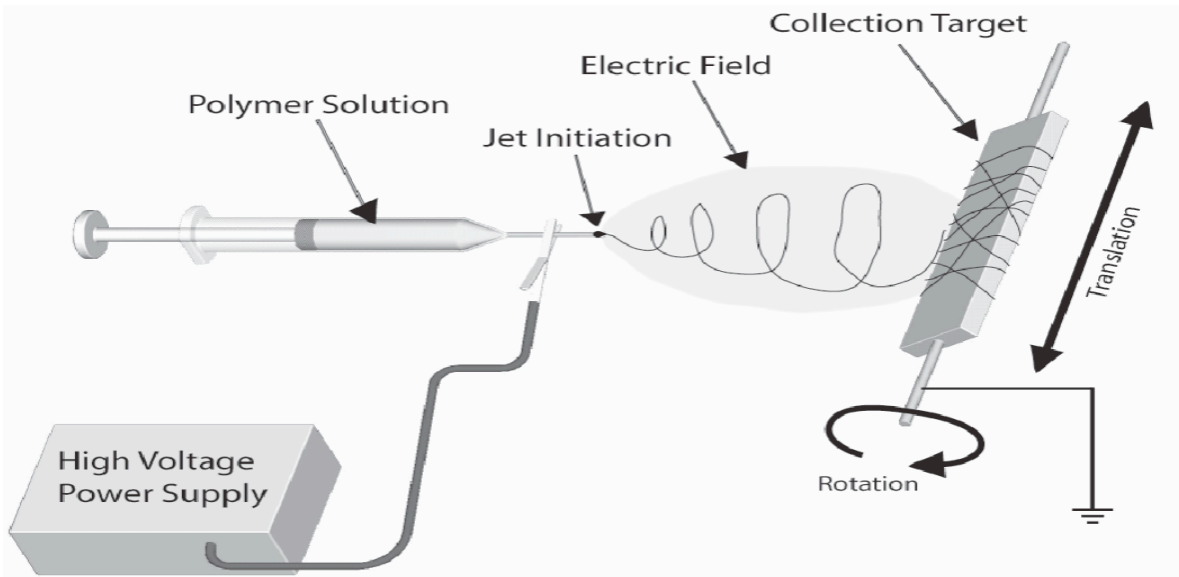

Fig. 7. Schematic of the Electrospinning process [16]. 


\section{Materials and Methods}

\section{Electrospinning}

PDO (Ethicon Inc.) and soluble elastin (Elastin Products Co., Inc) were dissolved in 1,1,1,3,3,3-hexafluoro-2-propanol (TCI America) in concentrations of $100 \mathrm{mg} / \mathrm{ml}$ and $200 \mathrm{mg} / \mathrm{ml}$ respectively. These solutions were blended in the ratios of 50:50, 70:30 and 90:10 (PDO:elastin) by volume. Pure PDO (100:0) and pure elastin (0:100) were also used in the study. In addition PDO was also dissolved in the concentrations of $60,80,100,120$ and $140 \mathrm{mg} / \mathrm{ml}$. These solutions were then loaded into a Becton Dickinson syringe $(5.0 \mathrm{ml})$ with an 18 gauge blunt tip needle and placed in a KD scientific syringe pump to be dispensed at a rate of 4-6 ml/hr (higher flow rates were used for high PDO ratio blends). Solutions were then electrospun onto a flat rotating stainless steel mandrel $(2.5 \mathrm{~cm}$ wide $\mathrm{x}$ $10.2 \mathrm{~cm}$ long $\times 0.3 \mathrm{~cm}$ thick) to produce a flat sheet. All electrospinning was performed at an applied voltage of $22 \mathrm{kV}$, while the mandrel was rotated at a rate of $500 \mathrm{rpm}$ and placed $12 \mathrm{~cm}$ away from the needle tip [5].

\section{Cross Linking}

Soluble elastin being a natural polymer lacks substantial strength upon hydration. Therefore, all elastin rich electrospun scaffolds were crosslinked using a method developed by Barnes et al. [35]. Briefly, the scaffolds were soaked for 18 hours in $167 \mathrm{mM}$ (50 fold 
molar excess for $200 \mathrm{mg} / \mathrm{ml}$ of elastin) of 1-ethyl-3-(3-dimethylaminopropyl) carbodiimide hydrochloride (EDC, Sigma Aldrich) solution in ethanol, followed by a 2 hour rinse in 0.1 M sodium phosphate. PDO and 90:10 blend did not require crosslinking, but were processed the same way in order to exclude any variability in the results.

\section{Permeability Measurement}

Circular discs were punched out of the scaffolds using a $10 \mathrm{~mm}$ biopsy punch and the permeability was individually measured using the simple flowmeter described in [36]. Briefly, the amount of time for a known volume of water to flow through a bound area of the scaffold was recorded and calculations were done using equation 1.

$$
\text { Permeability }=\underline{\mathrm{Q}}
$$

Where $\mathrm{Q}$ is the volume of water passed through the scaffold $(\mathrm{ml})$ in time $\mathrm{t}(\mathrm{min})$ and $\mathrm{A}$ and $\mathrm{h}$ are the area $\left(\mathrm{cm}^{2}\right)$ and the thickness $(\mathrm{cm})$ of the scaffold respectively. The distance between the water source (horizontal $10 \mathrm{~mL}$ pipette) and the scaffold was maintained at a level to produce a pressure head of $120 \mathrm{~mm} \mathrm{Hg} \mathrm{(Fig.8).}$ 


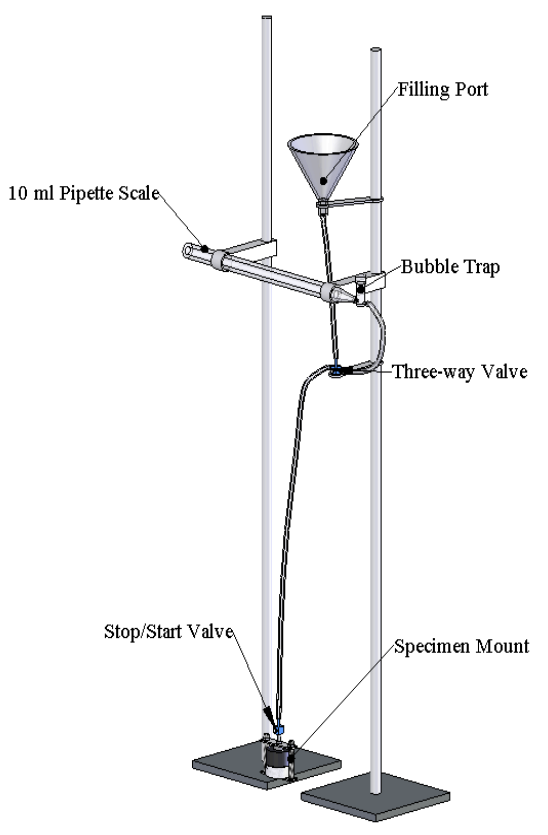

Fig. 8. Diagram of the permeability measurement device used in the study [36].

\section{Cell Culture}

Human peripheral blood monocytes (CRL-9855, ATCC) were seeded into culture at a density of $6 \times 10^{7}$ cells per $75 \mathrm{~cm}^{2}$ flask in Dulbecco's modified eagle medium (high glucose) with $20 \%$ heat inactivated fetal bovine serum and $10 \%$ heat inactivated $\mathrm{AB}+$ serum. This cell concentration provided a high seeding density for differentiation of monocytes to macrophages. Macrophages were obtained after 21 days of culture. It has been documented that serum proteins found in Human $\mathrm{AB}+$ Serum (e.g. Human Immunoglobulin (IgG)) promote maturation by interacting with monocytes via Fc receptors [37]. Monocytes also show macrophage characteristics such as increased 
cytolysis and intracellular levels of lysosomal enzymes in the presence of autologous serum [38]. Godiska et al. reported that the chemoattractant macrophage derived chemokine (MDC) has a very specific pattern of expression and is highly expressed by macrophages and monocyte-derived dendritic cells, but is not expressed by freshly isolated monocytes, granulocytic cells, or natural killer cells [39]. Macrophages were then adapted for culture in Macrophage-SFM (serum free media) (Invitrogen). A sequential adaptation technique was used to adapt the cells as a drastic change from $30 \%$ serum to a serum free media would have been too stressful for the cells. The ratio of serum supplemented media (SSM) to serum free media (SFM) was gradually reduced every week. For the first week cells were cultured in 80:20 (SSM:SFM). In the following week the ratio of media used was 50:50 and then a gradual increase in the amount of SFM media was made as the cells were cultured in 20:80, followed by $0: 100$. No changes in morphology or viability were observed after the adaptation. Monocytes and macrophages were cultured at a density of 50,000 cells/well in a 12 well plate and the supernatants were collected and stored at day 7 , 14, 21 and 28 until needed for the MDC expression analysis.

\section{Cell Seeding on Scaffolds}

Macrophages were adapted for culture in serum free media (Invitrogen). A serum free medium formulation was chosen to exclude the contribution of serum derived angiogenesis factors in the study. Conventional tissue culture techniques that frequently 
employ serum stimulate cells by various biological modifiers such as hormones, proteins and other biomolecules.

Prior to cell seeding the scaffolds were disinfected by soaking in ethanol for $10 \mathrm{~min}$ followed by repeated rinses in phosphate buffered saline (PBS). The macrophages were then seeded at a density of 400,000 cells/well on electrospun $(10 \mathrm{~mm})$ disks of PDO (60 to $140 \mathrm{mg} / \mathrm{ml})$, elastin, PDO:elastin blends (50:50, 70:30 and 90:10) and on tissue culture plastic (TCP) in a 48 well plate. The supernatants were collected on day 7, 14, 21 and 28 and stored at $-70^{\circ} \mathrm{C}$ until needed. One disc of each ratio was also removed at the above mentioned time points, fixed in $10 \%$ formalin and processed for histology (Hematoxylin and Eosin staining; $\mathrm{H} \& \mathrm{E})$.

\section{Enzyme Linked Immunosorbent Assay (ELISA)}

The growth factor expression was quantified using Enzyme Linked Immunosorbent Assay (ELISA). The cell culture supernatants were thawed and each ELISA for specific growth factors (VEGF, aFGF, bFGF, TGF- $\beta 1$ ) to be evaluated was carried out using construction kits (Antigenix America) as per manufacturer's instructions. The standard curve was generated using log-log fit (Soft MaxPro 4.8) and its linear part was used to determine the concentration of the factor in the supernatant. Latent TGF- $\beta 1$ was activated to its immuno-reactive form using the procedure outlined in the kit's instructions. 


\section{Statistical Analysis}

All statistical analysis of the data was based on a Kruskal-Wallis one way analysis of variance on ranks and a Tukey-Kramer pairwise multiple comparison procedure $(\alpha=0.05)$ performed with JMP ${ }^{\circledR}$ IN 7 statistical software (SAS Institute). 


\section{Results and Discussion}

\section{Permeability Measurement}

Statistically, PDO was significantly more permeable than the rest of the materials and 90:10 was more permeable than 70:30 and 50:50 (Fig.9). Therefore, cell infiltration can be directly related to the permeability of the scaffold. It can be concluded that PDO and the 90:10 blend have high porosities as pore size is directly proportional to the permeability and the fiber diameter of the electrospun scaffolds. Sanders et al. reported reduced macrophage density on small diameter fibers $(<6 \mu \mathrm{m})$ attributed to a reduced cell material contact surface area [40]. The permeability test results for the different concentrations of the PDO scaffold showed that $100 \mathrm{mg} / \mathrm{ml}$ and $120 \mathrm{mg} / \mathrm{ml} \mathrm{scaffolds}$ were statistically significantly different from the $60 \mathrm{mg} / \mathrm{ml}$ and $80 \mathrm{mg} / \mathrm{ml} \mathrm{scaffolds}$. Also, the permeability within each of these two groups was not significantly different from one another. However, the $140 \mathrm{mg} / \mathrm{ml}$ scaffold was not statistically different from the 60 $\mathrm{mg} / \mathrm{ml}$ and $80 \mathrm{mg} / \mathrm{ml} \mathrm{scaffolds.}$

It has been documented that pore size of PDO scaffolds increases linearly with concentration. The reason why the permeability peaks at about $120 \mathrm{mg} / \mathrm{ml}$ and falls dramatically for $140 \mathrm{mg} / \mathrm{ml}$ scaffold could be attributed to the pore collapse of these structures. It could have been that the pores and fibers were so large that the pores actually collapsed under the water pressure and the void spaces were filled with fibers since the entire scaffold is dynamic and can move around on a micron scale level (Fig.10). 


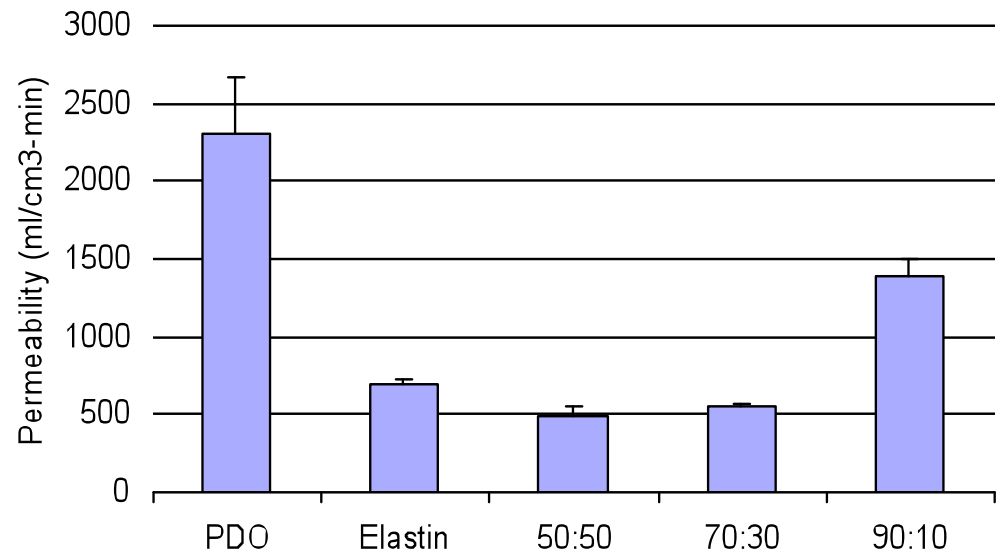

Fig. 9. Permeability measurements for samples of electrospun PDO:elastin scaffolds. Error bars indicate standard error of the mean.

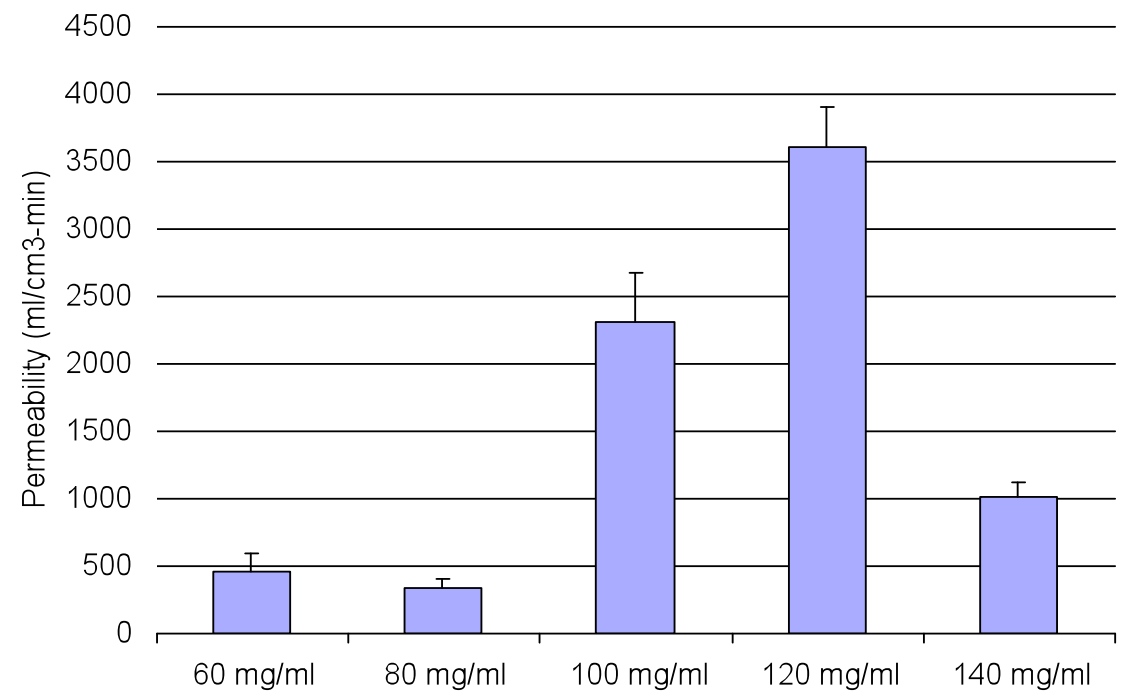

Fig. 10. Permeability measurements for samples of electrospun PDO scaffolds of varying concentration. Error bars indicate standard error of the mean. 


\section{Macrophage Derived Chemokine ELISA}

In order to confirm the maturation of monocytes to macrophages a Macrophage Derived Chemokine (MDC) (R\&D Systems) ELISA was performed. This was based on the fact that macrophages produce MDC constitutively while monocytes release it only upon stimulation [39]. Significant statistical differences were found on day 21 of culture (Fig.11). Statistical differences were not observed on the other days. However, it was seen that both monocytes and macrophages were producing comparable amounts of MDC. This can be explained by taking into account the fact that a mixed cell population was purchased from ATCC. In addition, it has been documented that after 7 days of culture in serum free media monocytes transform into macrophages [1]. In another example, human peripheral blood monocytes cultured in $10 \%$ autologous serum were shown to have differentiated to macrophages after 5-6 days [41, 42]. They also reported that the number of adherent cells were similar when grown in the presence of $\mathrm{AB}$ serum or autologous serum [42]. The MDC expression was also found to be consistent from day 7 to 28 , however it is unclear what the baseline measurements (day 0) would reveal. 


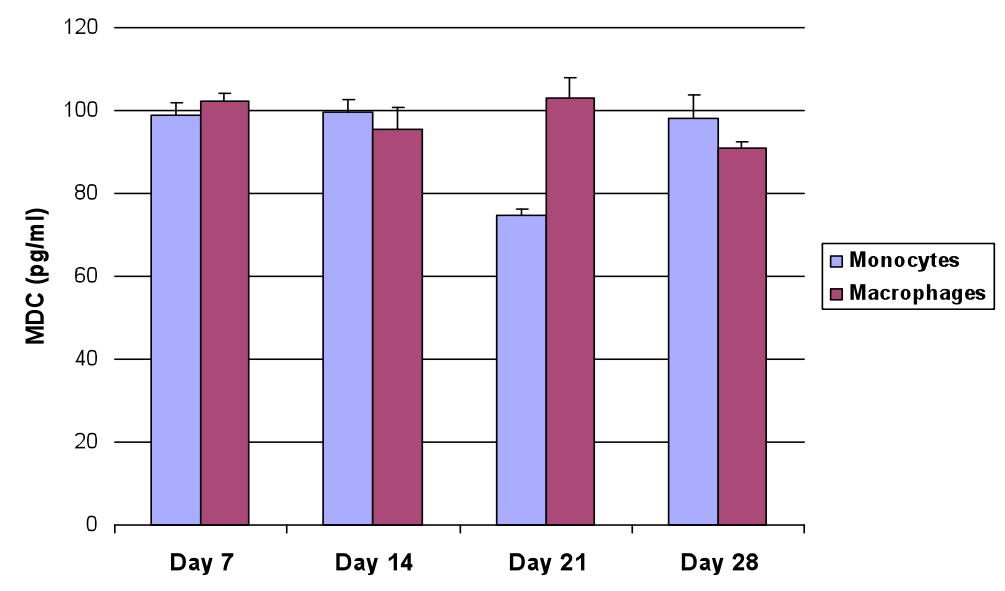

Fig. 11. Quantification of MDC production by macrophages and monocytes. Error bars indicate standard error of the mean.

\section{Macrophage Factor Secretion (Quantification by ELISA)}

The growth factor expression analysis revealed that macrophages released high amounts of VEGF and aFGF with a steady increase from day 7 to 28 . The expression of TGF- $\beta 1$ was relatively low. The production of bFGF was below the detectable level (10 $\mathrm{pg} / \mathrm{ml}$ ) of the kit. The activation of macrophages in this case is theorized to be integrin mediated. Integrins are a large family of cell surface receptors that mediate cellextracellular matrix and intracellular interactions. Enough information is not available to provide insight into how activation may occur when cells encounter engineered materials composed of proteins and synthetic polymers.

As shown in figure 12, the expression of VEGF on biomaterial adherent macrophages did not vary considerably among the different scaffolds. The secretion of aFGF and VEGF was found to remain largely independent of the scaffold material. The production of both aFGF and VEGF showed a steady increase from day 7 to 28 . VEGF 
secretion on day 28 was found to be statistically higher than day 7 on all materials. The secretion of aFGF on day 28 was found to be higher than both day 7 and 14 on all materials. This indicates that the production of both aFGF and VEGF was found to be significantly higher in later stages of cell culture.

The expression of TGF- $\beta 1$ gradually decreased from day 7 to 21 and came back up again on day 28 . The only exceptions to this trend were the PDO and the 70:30 scaffold. Statistically significant differences were found in TGF- $\beta 1$ secretion between PDO and PDO:elastin (90:10) blend on day 7. Macrophages secrete TGF- $\beta 1$ as well as its binding protein. The binding protein inhibits the interaction of TGF- $\beta 1$ with its cell surface receptor, thus showing that TGF- $\beta 1$-binding protein complex is biologically inactive. This interaction modulates the expression and action of TGF- $\beta 1$.

Figure 13 shows the growth factor expression on PDO scaffolds of varying concentrations. It was observed that the growth factor secretion was significantly higher on high PDO concentration scaffolds. The only exception to this trend was the secretion of TGF- $\beta 1$ and aFGF on the $80 \mathrm{mg} / \mathrm{ml}$ scaffold which was significantly higher than the $140 \mathrm{mg} / \mathrm{ml}$ scaffold on day 21 . Similar results were obtained again in the expression of TGF- $\beta 1$ as its concentration went progressively low from day 7 to 21 and came back up again on day 28 . The only exception to this trend was the $100 \mathrm{mg} / \mathrm{ml}$ PDO scaffold. 60 $\mathrm{mg} / \mathrm{ml}$ scaffold showed a rather constant level of TGF- $\beta 1$ production from day 7 to 28 . VEGF secretion was found to be largely material independent. It was also found that VEGF production was significantly higher on day 28 as compared to day 7 on all concentrations of PDO. A detailed statistical report is provided in the appendix for other statistical differences not reported in the text. 
It was observed that the growth factor secretion on scaffolds was comparable to the growth factor secretion on tissue culture plastic. This shows that the materials are neither elevating nor suppressing the secretory function of macrophages. It can be anticipated that these materials as vascular implants will support natural tissue regeneration process with minimum risk of tumors or undesirable inflammatory reactions. Too much of growth factor secretion can lead to uncontrolled cell migration and proliferation. There are reports of 'leaky' blood vessels which exhibit fibrosis, oedema, inflammation and haemorrhagic ulcers due to over expression of VEGF and TGF- $\beta 1[15,43]$.

The degradation activity of macrophages was observed to be higher on scaffolds containing high ratios of PDO. This can be attributed to the high permeability of these materials, which enabled good infiltration of macrophages throughout the entire thickness of the scaffold. Permeability is directly related to the pore size and the fiber diameter. It is known that increase in fiber size is associated with an increase in pore size. Drastic $\mathrm{pH}$ changes were observed in the cell culture media on various samples. Low $\mathrm{pH}$ was generated in the microenvironment of the scaffolds containing high PDO ratios, indicating that they are undergoing degradation. Previous studies have shown that low $\mathrm{pH}$ stimulates macrophages to release growth factors [44]. 

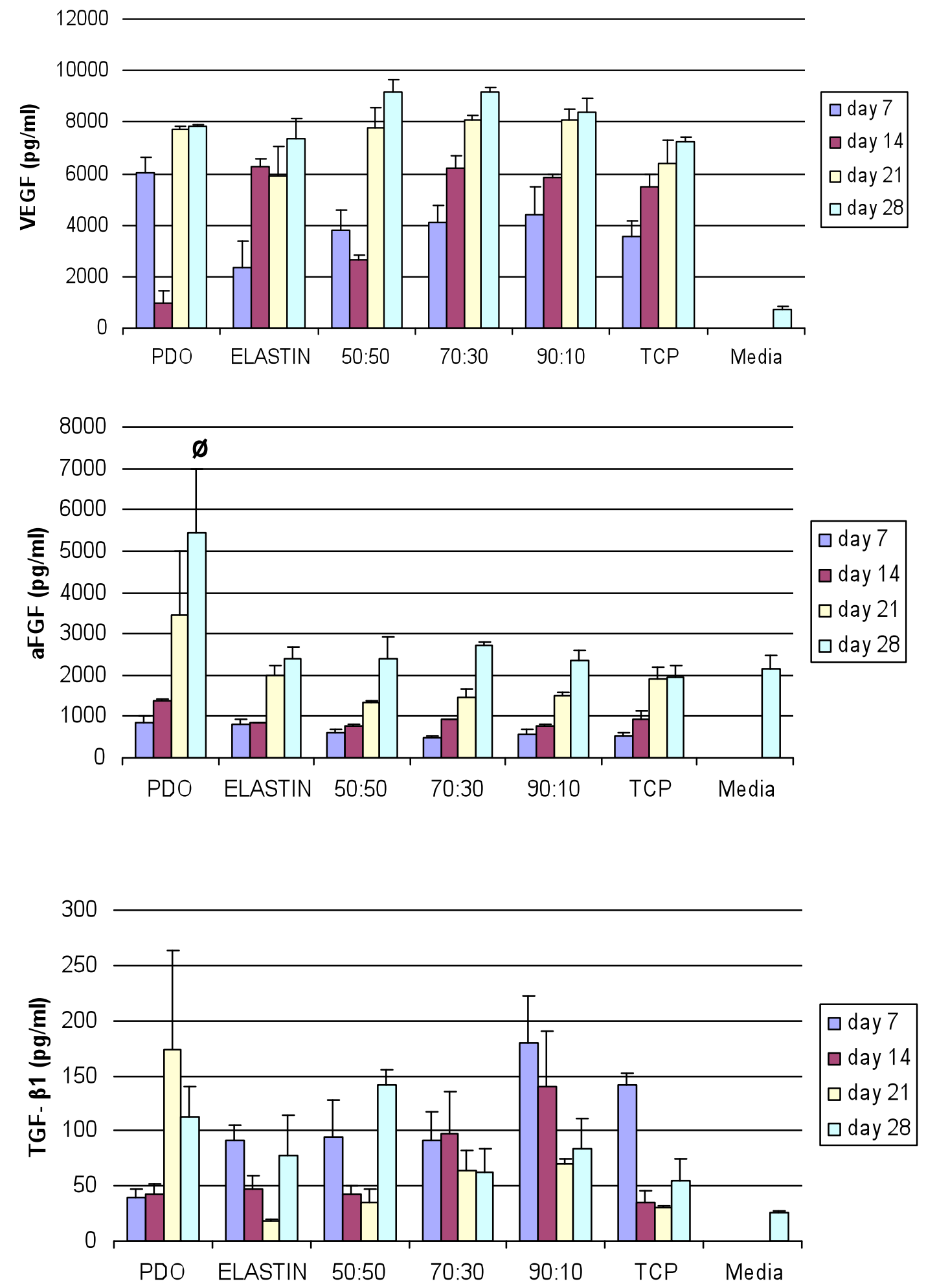

Fig. 12. Quantification of macrophage secretory activity on PDO:elastin scaffolds using ELISA. Error bars indicate standard error of the mean. Symbols ' $*$ ' and ' $\varnothing$ ' indicate a statistically significant difference from the control groups, media and TCP respectively $(\mathrm{p}<0.05)$. 

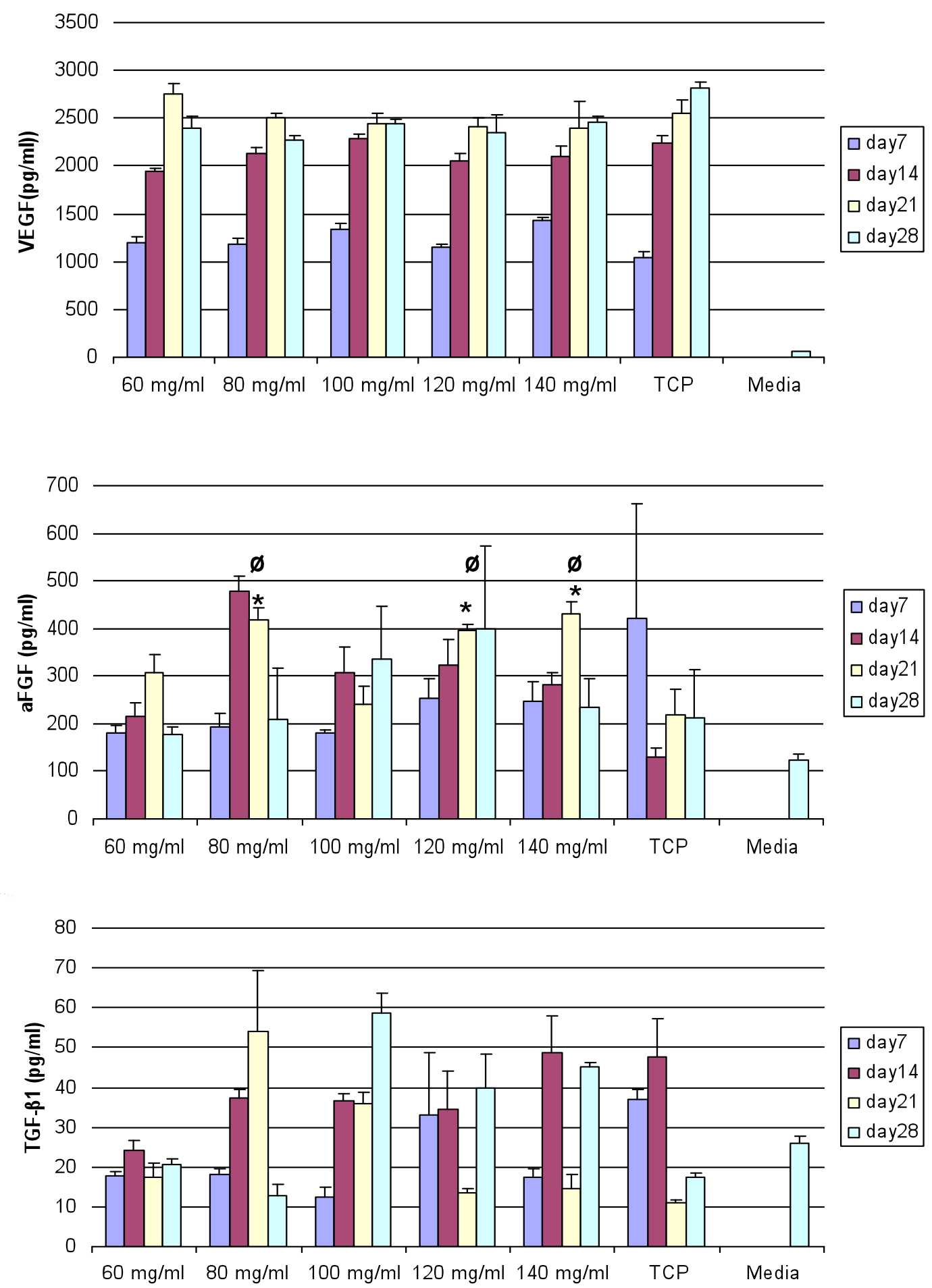

Fig. 13. Quantification of macrophage secretory activity on PDO scaffolds of varying concentrations using ELISA. Error bars indicate standard error of the mean. Symbols '*' and ' $\varnothing$ ' indicate a statistically significant difference from the control groups, media and TCP respectively $(\mathrm{p}<0.05)$. 


\section{Histology}

Histology revealed greater cell infiltration into the fibrous networks of the PDO and 90:10 scaffolds (Fig.14). The cells migrated to some extent on the elastin scaffold and remained on the surface of the 50:50 and the 70:30 blend. It has been documented that when angiogenesis occurs in a remodeling situation such as a bioresorbable vascular prosthetic, it is accompanied by an inflammatory infiltration composed of monocytes and macrophages. The abolishment of this infiltration dramatically reduces the angiogenesis and wound healing response [45]. Also, it has been reported that the number of macrophages directly correlate to the degree of angiogenesis [46, 47]. To evaluate the effect of porosity on the infiltration of macrophages in the scaffold, PDO scaffolds were electrospun in the range of $60 \mathrm{mg} / \mathrm{ml}$ to $140 \mathrm{mg} / \mathrm{ml}$. The increasing concentration correlates to the increasing fiber diameter and pore size. It has been documented that the diameter of PDO fibers increased linearly from 0.18 to $1.4 \mu \mathrm{m}$ range as the solution concentration increased in the range $42-167 \mathrm{mg} / \mathrm{ml}$. The pore size however exhibited a non-linear relation with solution concentration. It was found to increase from $0.5 \mu \mathrm{m}^{2}$ to $24.5 \mu \mathrm{m}^{2}$ as solution concentration increased from 42 to $167 \mathrm{mg} / \mathrm{ml}$. The statistical analysis indicated that the $42-56 \mathrm{mg} / \mathrm{ml}$ pore areas were significantly different from the $71-167 \mathrm{mg} / \mathrm{ml}$ pore areas, though the pore areas within each of those groups were not significantly different from each other. Porosity and surface area are two key variables influencing interaction of structures with the host environment. For example, a highly porous structure with a large surface area may be more favorable to cell attachment and infiltration of cellular components [16]. The current study is in agreement with this fact. 
As shown in Figure 15, the macrophages did not migrate at all into the fibrous networks of $60 \mathrm{mg} / \mathrm{ml}$ and $80 \mathrm{mg} / \mathrm{ml}$ PDO scaffolds. They largely remained on the surface and did not migrate through even at day 21 of culture. On the other hand, scaffolds spun at concentrations of $100 \mathrm{mg} / \mathrm{ml}, 120 \mathrm{mg} / \mathrm{ml}$ and $140 \mathrm{mg} / \mathrm{ml}$ showed increased cell migration and infiltration throughout the entire thickness of the scaffold. Thus, it can be concluded that the macrophages did not infiltrate elastin and 50:50 scaffolds due to the highly compact and dense structure of these scaffolds which led to low pore size.

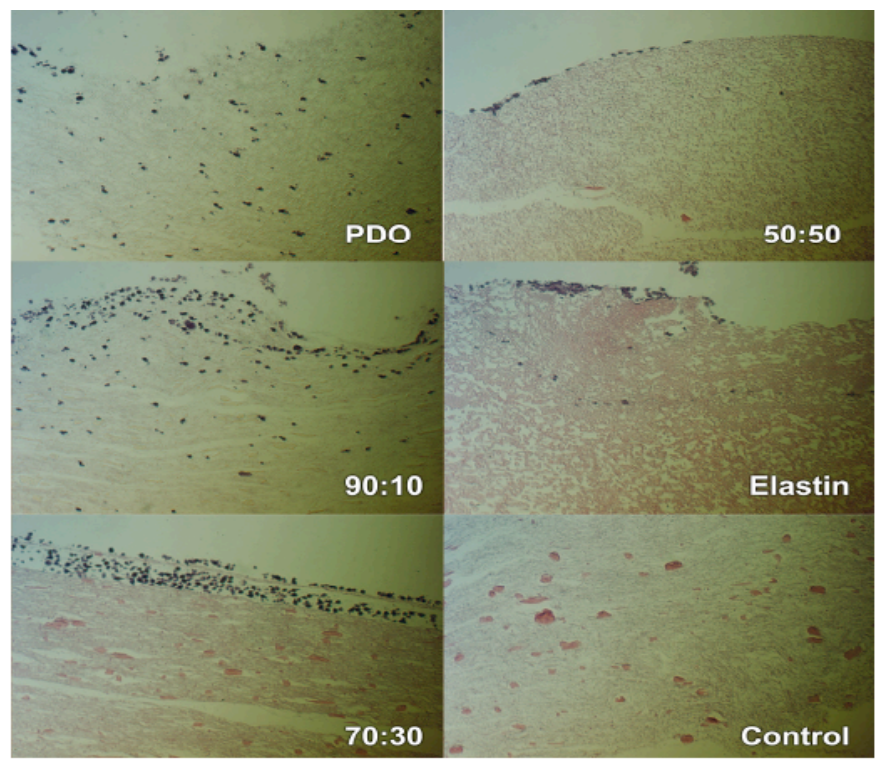

Fig. 14. Histology (H\&E) performed at day 21(20x magnification). 


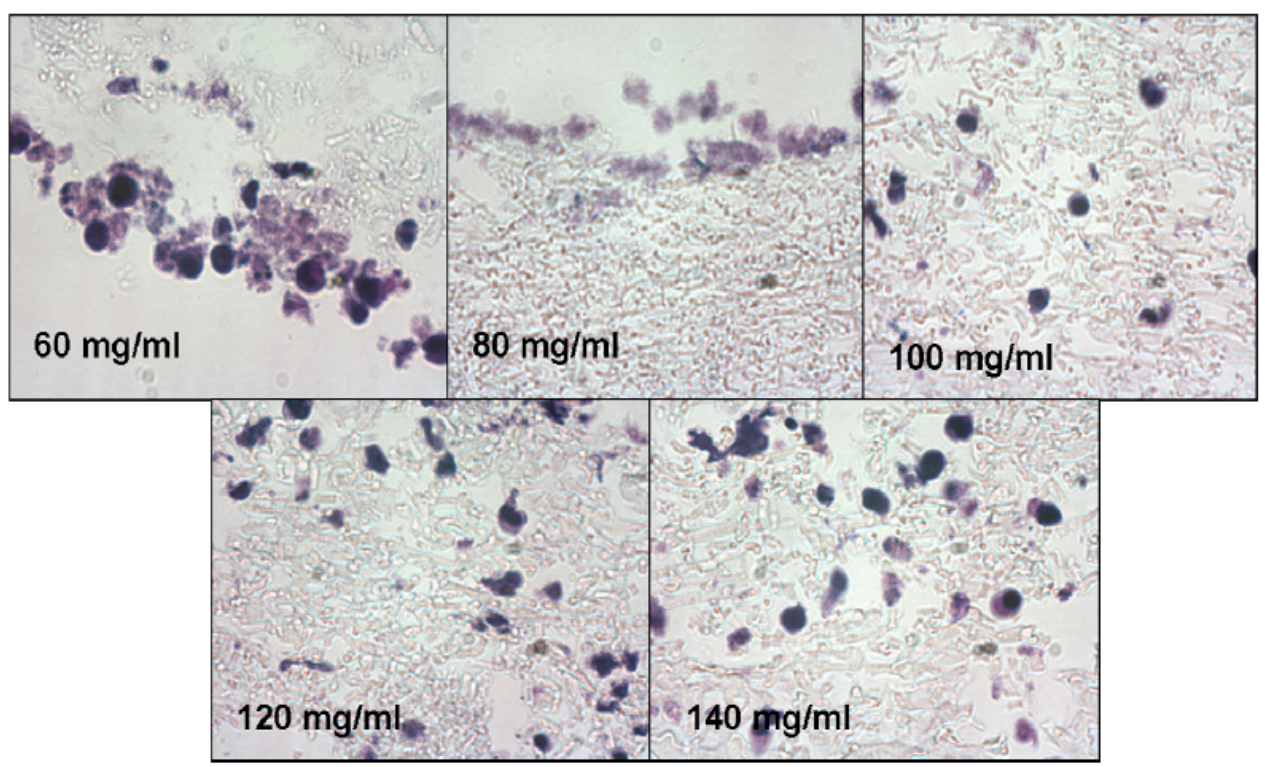

Fig. 15. Histology performed on various concentrations of PDO at day 21 (40x magnification). 


\section{Conclusion}

Biomaterials upon implantation acquire a layer of host proteins prior to interacting with host cells. The type, concentration and conformations of these surface adsorbed proteins are dependent on the material surface properties [14]. Macrophage adhesion to the material surface adherent protein layer is integrin mediated. It provides intracellular signals that dictate macrophage behavior. A cascade of events are triggered that affect cytoskeletal rearrangements and formation of adhesion structures. Macrophages undergo cytoskeletal remodeling to spread over the material surface. When cells are properly adhered to the cell surface, integrin signaling mediates survival. Disruption of the adhesion signals lead to anoikis (term for apoptosis induced by cell detachment from its supportive matrix) [14]. The adherent macrophages become activated in order to phagocytose the biomaterial. This is followed by cytokine secretion that directs the inflammatory and wound healing response to the biomaterial. In vitro testing of growth factor profiles released by adherent macrophages can be an initial means of assaying biocompatibility [14].

The study provides an angiogenic assessment of macrophage implant interaction by quantifying the growth factor secretion in the cell culture supernatants. It was observed that the growth factor secretion profiles for VEGF and aFGF attained similar levels around day 21 and 28 for all materials. Previous studies have shown that macrophages do not produce bFGF on biomaterials unless they are stimulated by 
concanavalin A or lipopolysaccharide [1]. The fact that bFGF expression is strong in chronic inflammations and weak in healthy tissue is also known. It has also been established in that bFGF is not absolutely mandatory for angiogenesis and that vascularization does occur in its absence [12].

Elastin incorporation into the scaffolds was done to improve the in vitro bioactivity of the matrix and also to improve the mechanical properties of the material [5]. The study however shows better results on scaffolds with high PDO ratios as compared to the elastin rich scaffolds. The increased cell migration and proliferation on PDO and the 90:10 blend can be largely attributed to the high porosities of these materials. Therefore, it can be concluded that scaffolds with high PDO ratios were more conducive to tissue regeneration and angiogenesis with minimum risk of thrombosis. 
$\underline{\text { Literature Cited }}$ 


\section{References}

1. Dagtekin, G., et al., Modulation of angiogenic functions in human macrophages by biomaterials. Biomaterials, 2003. 24(20): p. 3395-401.

2. Xia, Z. and J.T. Triffitt, A review on macrophage responses to biomaterials. Biomed Mater, 2006. 1(1): p. R1-9.

3. Zakrzewska, M., E. Marcinkowska, and A. Wiedlocha, FGF-1: from biology through engineering to potential medical applications. Crit Rev Clin Lab Sci, 2008. 45(1): p. 91-135.

4. Huang L, M.R.A., Apkarian R P, Pourdeyhimi B, Conticello V P, Chaikof E L, Generation of synthetic elastin-mimetic small diameter fibers and fibre networks. Macromolecules, 2000. 33: p. 2989-97.

5. Sell, S.A., et al., Electrospun polydioxanone-elastin blends: potential for bioresorbable vascular grafts. Biomed Mater, 2006. 1(2): p. 72-80.

6. Patel, A., et al., Elastin biosynthesis: The missing link in tissue-engineered blood vessels. Cardiovasc Res, 2006. 71(1): p. 40-9.

7. Sunderkotter, C., et al., Macrophages and angiogenesis. J Leukoc Biol, 1994. 55(3): p. 410-22.

8. Lewis, C.E. and J.O.D. McGee, The macrophage. 1992.

9. Janeway, Immunobiology. 2005.

10. Lamagna, C., M. Aurrand-Lions, and B.A. Imhof, Dual role of macrophages in tumor growth and angiogenesis. J Leukoc Biol, 2006. 80(4): p. 705-13. 
11. Gordon, S., Alternative activation of macrophages. Nat Rev Immunol, 2003. 3(1): p. 23-35.

12. Shiu, Y.T., et al., The role of mechanical stresses in angiogenesis. Crit Rev Biomed Eng, 2005. 33(5): p. 431-510.

13. Greisler, H.P., et al., Derivation of neointima in vascular grafts. Circulation, 1988. 78(3 Pt 2): p. I6-12.

14. Anderson, J.M., A. Rodriguez, and D.T. Chang, Foreign body reaction to biomaterials. Semin Immunol, 2008. 20(2): p. 86-100.

15. Sunderkotter, C., et al., Macrophage-derived angiogenesis factors. Pharmacol Ther, 1991. 51(2): p. 195-216.

16. Boland, E.D., et al., Electrospinning polydioxanone for biomedical applications. Acta Biomater, 2005. 1(1): p. 115-23.

17. Swartbol, P., et al., Tumor necrosis factor-alpha and interleukin-6 release from white blood cells induced by different graft materials in vitro are affected by pentoxifylline and iloprost. J Biomed Mater Res, 1997. 36(3): p. 400-6.

18. Wesolowski, S.A., et al., The compound prosthetic vascular graft: a pathologic survey. Surgery, 1963. 53: p. 19-44.

19. Ruderman, R.J., et al., A partially biodegradable vascular prosthesis. Trans Am Soc Artif Intern Organs, 1972. 18(0): p. 30-7.

20. Bowald, S., C. Busch, and I. Eriksson, Arterial regeneration following polyglactin 910 suture mesh grafting. Surgery, 1979. 86(5): p. 722-9. 
21. Greisler, H.P., Arterial regeneration over absorbable prostheses. Arch Surg, 1982. 117(11): p. 1425-31.

22. Greisler, H.P., et al., Arterial regenerative activity after prosthetic implantation. Arch Surg, 1985. 120(3): p. 315-23.

23. Atala, A. and R.P. Lanza, Methods of Tissue Engineering. 2002.

24. Greisler, H.P., et al., Compound polyglactin 910/polypropylene small vessel prostheses. J Vasc Surg, 1987. 5(4): p. 572-83.

25. Greisler, H.P., et al., Polyglactin 910/polydioxanone bicomponent totally resorbable vascular prostheses. J Vasc Surg, 1988. 7(5): p. 697-705.

26. Greisler, H.P., et al., Arterial regeneration over polydioxanone prostheses in the rabbit. Arch Surg, 1987. 122(6): p. 715-21.

27. Schwarcz, T.H., et al., Prostaglandin content of tissue lining vascular prostheses. Curr Surg, 1987. 44(1): p. 18-21.

28. Zhang, Y., et al., Electrospinning of gelatin fibers and gelatin/PCL composite fibrous scaffolds. J Biomed Mater Res B Appl Biomater, 2005. 72(1): p. 156-65.

29. Casper, C.L., et al., Functionalizing electrospun fibers with biologically relevant macromolecules. Biomacromolecules, 2005. 6(4): p. 1998-2007.

30. Boland, E.D., et al., Electrospinning collagen and elastin: preliminary vascular tissue engineering. Front Biosci, 2004. 9: p. 1422-32.

31. Brodbeck, W.G., et al., Biomaterial surface chemistry dictates adherent monocyte/macrophage cytokine expression in vitro. Cytokine, 2002. 18(6): p. 3119. 
32. Salthouse, T.N., Some aspects of macrophage behavior at the implant interface. Journal of Biomedical Materials Research, 1984. 18: p. 395-401.

33. Ratner, B.D. and S.J. Bryant, Biomaterials: where we have been and where we are going. Annu Rev Biomed Eng, 2004. 6: p. 41-75.

34. Zheng-Ming Huang, Y.-Z.Z., M. Kotaki, S. Ramakrishna, A review on polymer nanofibers by electrospinning and their applications in nanocomposites. Composite Science and Technology, 2003(63): p. 2223-2253.

35. Barnes, C.P., et al., Cross-linking electrospun type II collagen tissue engineering scaffolds with carbodiimide in ethanol. Tissue Eng, 2007. 13(7): p. 1593-605.

36. Sell, S., et al., Scaffold permeability as a means to determine fiber diameter and pore size of electrospun fibrinogen. J Biomed Mater Res A, 2008. 85(1): p. 115-26.

37. Akiyama, Y., et al., Effects of adherence, activation and distinct serum proteins on the in vitro human monocyte maturation process. J Leukoc Biol, 1988. 43(3): p. 224-31.

38. Musson, R.A., Human serum induces maturation of human monocytes in vitro. Changes in cytolytic activity, intracellular lysosomal enzymes, and nonspecific esterase activity. Am J Pathol, 1983. 111(3): p. 331-40.

39. Godiska, R., et al., Human macrophage-derived chemokine (MDC), a novel chemoattractant for monocytes, monocyte-derived dendritic cells, and natural killer cells. J Exp Med, 1997. 185(9): p. 1595-604. 
40. Sanders, J.E., C.E. Stiles, and C.L. Hayes, Tissue response to single-polymer fibers of varying diameters: evaluation of fibrous encapsulation and macrophage density. J Biomed Mater Res, 2000. 52(1): p. 231-7.

41. Stafforini, D.M., et al., Human macrophages secret platelet-activating factor acetylhydrolase. J Biol Chem, 1990. 265(17): p. 9682-7.

42. Seager Danciger, J., et al., Method for large scale isolation, culture and cryopreservation of human monocytes suitable for chemotaxis, cellular adhesion assays, macrophage and dendritic cell differentiation. J Immunol Methods, 2004. 288(1-2): p. 123-34.

43. Nillesen, S.T., et al., Increased angiogenesis and blood vessel maturation in acellular collagen-heparin scaffolds containing both FGF2 and VEGF. Biomaterials, 2007. 28(6): p. 1123-31.

44. Galletti, P.M., et al., Experience with fully bioresorbable aortic grafts in the dog. Surgery, 1988. 103(2): p. 231-41.

45. Moldovan, N.I., Role of monocytes and macrophages in adult angiogenesis: a light at the tunnel's end. J Hematother Stem Cell Res, 2002. 11(2): p. 179-94.

46. Torisu, H., et al., Macrophage infiltration correlates with tumor stage and angiogenesis in human malignant melanoma: possible involvement of TNFalpha and IL-1alpha. Int J Cancer, 2000. 85(2): p. 182-8.

47. Ono, M., et al., Biological implications of macrophage infiltration in human tumor angiogenesis. Cancer Chemother Pharmacol, 1999. 43 Suppl: p. S69-71. 


\section{APPENDIX A: Statistical Analysis}

\section{Oneway Analysis of Day 7 By PDO:elastin scaffolds for VEGF secretion}

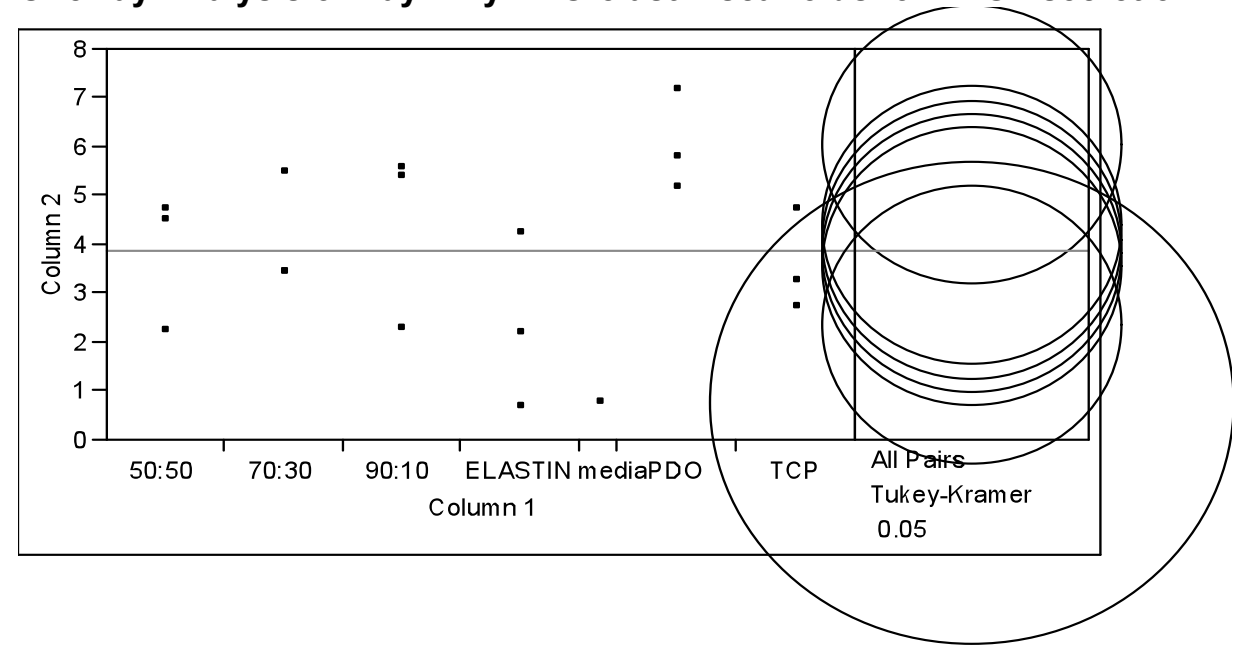

\section{Means Comparisons}

Comparisons for all pairs using Tukey-Kramer HSD

$\begin{array}{rr}\mathbf{q}^{*} & \text { Alpha } \\ 3.49978 & 0.05\end{array}$

\begin{tabular}{|l|r|r|r|r|r|r|r|}
\hline Abs(Dif)-LSD & PDO & $\mathbf{9 0 : 1 0}$ & $\mathbf{7 0 : 3 0}$ & $\mathbf{5 0 : 5 0}$ & TCP & ELASTIN & media \\
\hline PDO & -4.0523 & -2.4293 & -2.1203 & -1.8493 & -1.5883 & -0.3780 & -0.4572 \\
\hline $90: 10$ & -2.4293 & -4.0523 & -3.7433 & -3.4723 & -3.2113 & -2.0010 & -2.0802 \\
\hline $70: 30$ & -2.1203 & -3.7433 & -4.0523 & -3.7813 & -3.5203 & -2.3100 & -2.3892 \\
\hline $50: 50$ & -1.8493 & -3.4723 & -3.7813 & -4.0523 & -3.7913 & -2.5810 & -2.6602 \\
\hline TCP & -1.5883 & -3.2113 & -3.5203 & -3.7913 & -4.0523 & -2.8420 & -2.9212 \\
\hline ELASTIN & -0.3780 & -2.0010 & -2.3100 & -2.5810 & -2.8420 & -4.0523 & -4.1316 \\
\hline media & -0.4572 & -2.0802 & -2.3892 & -2.6602 & -2.9212 & -4.1316 & -7.0189 \\
\hline
\end{tabular}

Positive values show pairs of means that are significantly different.

$\begin{array}{llr}\text { Level } & & \begin{array}{r}\text { Mean } \\ \text { PDO }\end{array} \\ 90: 10 & \text { A } & 6.0166667 \\ 70: 30 & \text { A } & 4.3936667 \\ 50: 50 & \text { A } & 4.0846667 \\ \text { TCP } & \text { A } & 3.8136667 \\ \text { ELASTIN } & \text { A } & 3.5526667 \\ \text { media } & \text { A } & 2.3423333 \\ & \text { A } & 0.7430000\end{array}$

Levels not connected by same letter are significantly different.

Level - Level Difference Lower CL Upper CL Difference 


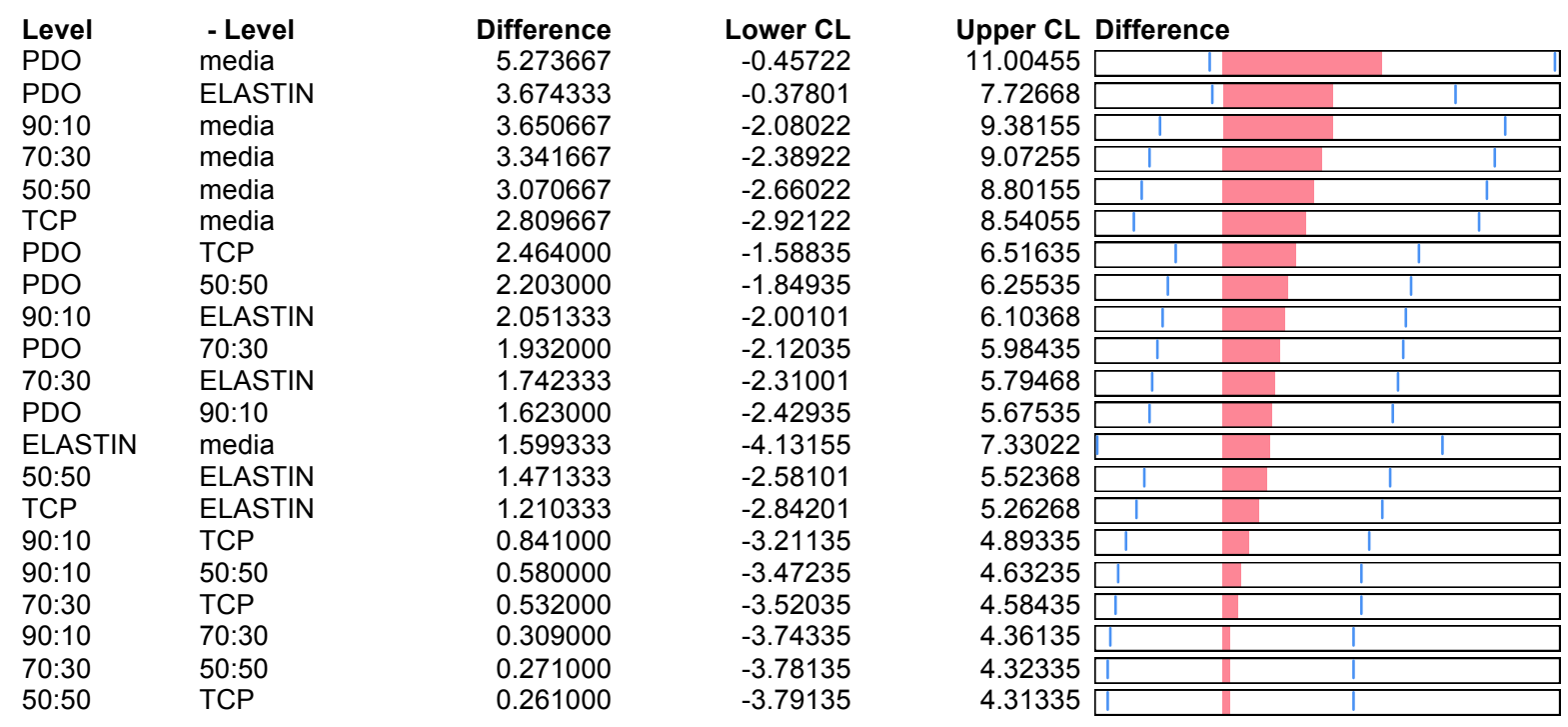

Oneway Analysis of Day 14 By PDO:elastin scaffolds for VEGF secretion

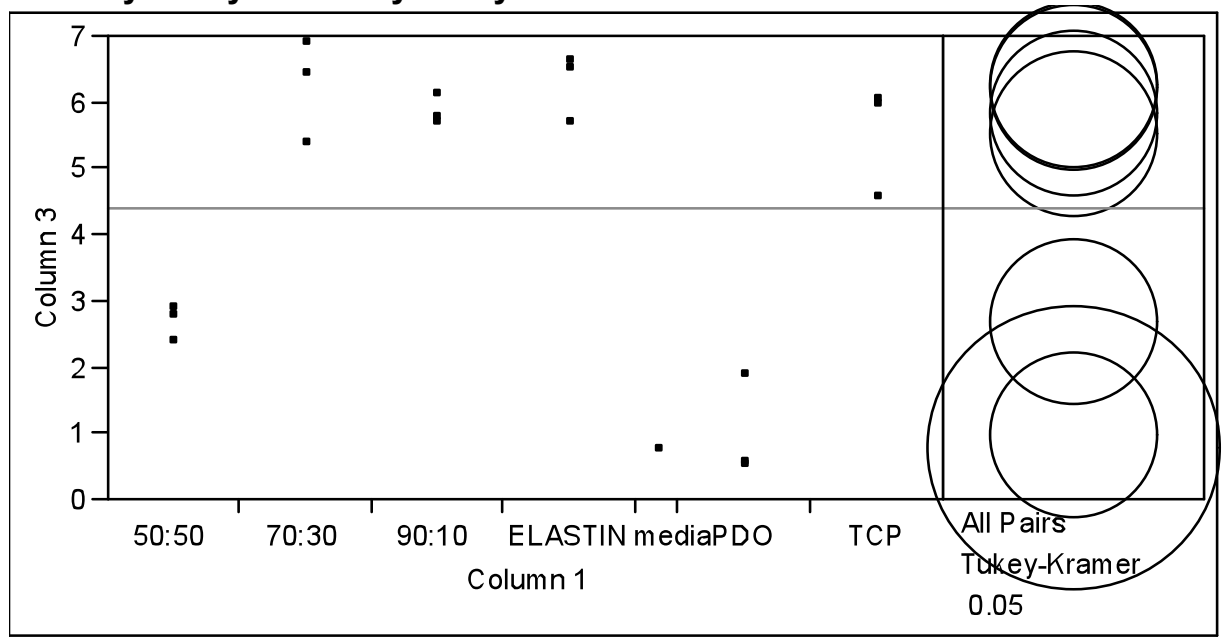

\section{Means Comparisons}

Comparisons for all pairs using Tukey-Kramer HSD

3.49978

Alpha
0.05

\begin{tabular}{|l|r|r|r|r|r|r|r|}
\hline Abs(Dif)-LSD & ELASTIN & $\mathbf{7 0 : 3 0}$ & $\mathbf{9 0 : 1 0}$ & TCP & $\mathbf{5 0 : 5 0}$ & PDO & media \\
\hline ELASTIN & -1.7627 & -1.7277 & -1.3520 & -1.0160 & 1.8230 & 3.5176 & 3.0188 \\
\hline $70: 30$ & -1.7277 & -1.7627 & -1.3870 & -1.0510 & 1.7880 & 3.4826 & 2.9838 \\
\hline $90: 10$ & -1.3520 & -1.3870 & -1.7627 & -1.4267 & 1.4123 & 3.1070 & 2.6081 \\
\hline TCP & -1.0160 & -1.0510 & -1.4267 & -1.7627 & 1.0763 & 2.7710 & 2.2721 \\
\hline $50: 50$ & 1.8230 & 1.7880 & 1.4123 & 1.0763 & -1.7627 & -0.0680 & -0.5669 \\
\hline PDO & 3.5176 & 3.4826 & 3.1070 & 2.7710 & -0.0680 & -1.7627 & -2.2615 \\
\hline media & 3.0188 & 2.9838 & 2.6081 & 2.2721 & -0.5669 & -2.2615 & -3.0531 \\
\hline
\end{tabular}

Positive values show pairs of means that are significantly different. 


$\begin{array}{lrrr}\text { Level } & & & \text { Mean } \\ \text { ELASTIN } & \text { A } & & 6.2546667 \\ 70: 30 & \text { A } & & 6.2196667 \\ 90: 10 & \text { A } & & 5.8440000 \\ \text { TCP } & \text { A } & & 5.5080000 \\ 50: 50 & & \text { B } & 2.6690000 \\ \text { PDO } & & \text { B } & 0.9743333 \\ \text { media } & & \text { B } & 0.7430000\end{array}$

Levels not connected by same letter are significantly different.

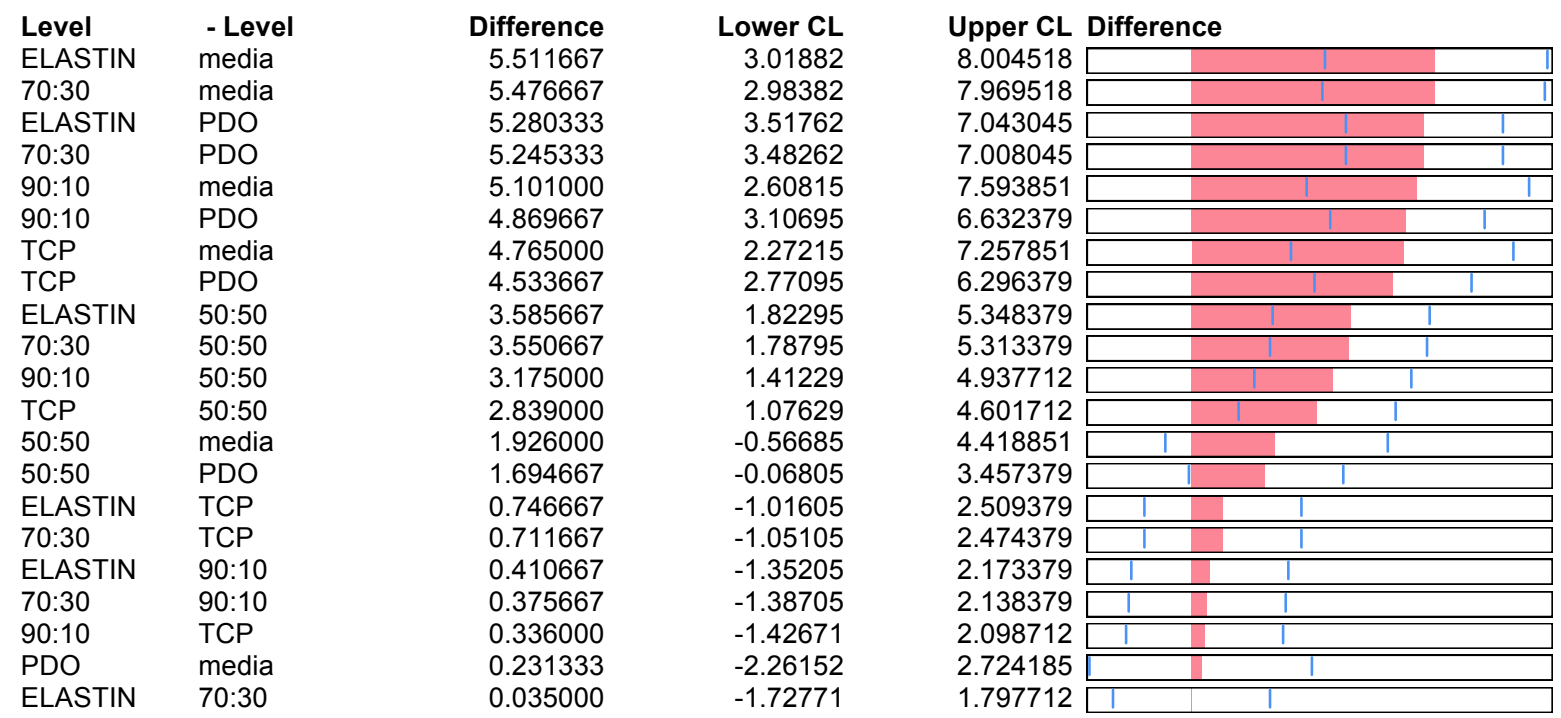

Oneway Analysis of Day 21 By PDO:elastin scaffolds for VEGF secretion

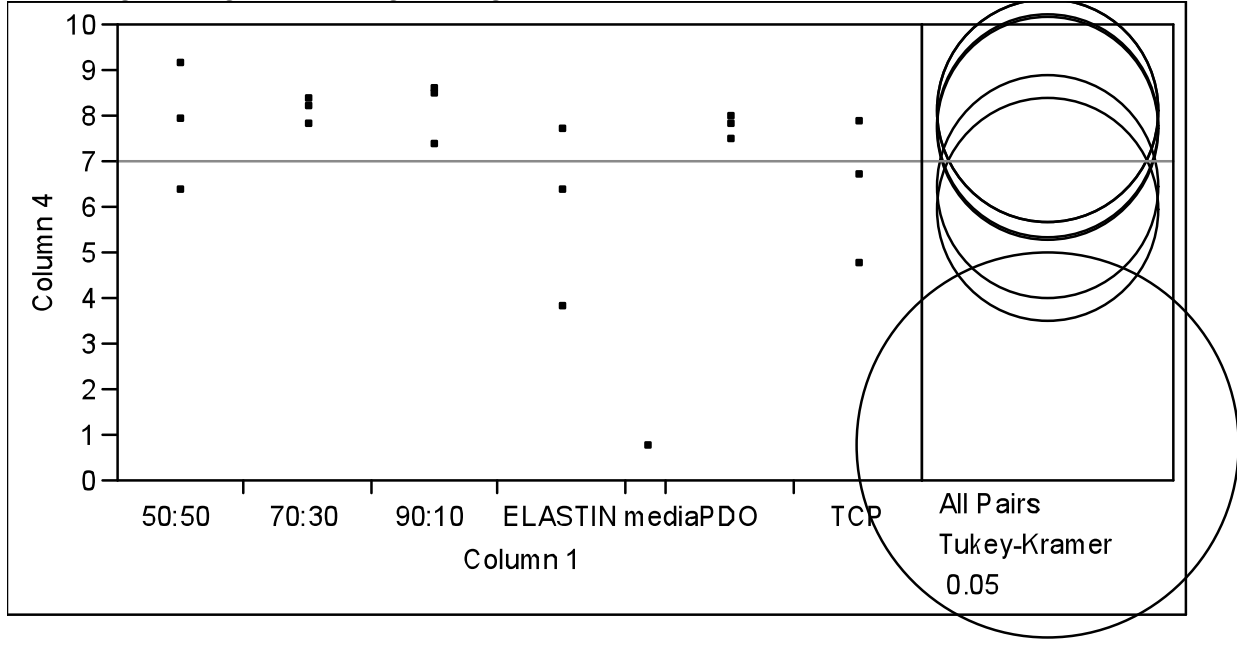

Means Comparisons

Comparisons for all pairs using Tukey-Kramer HSD

$\mathbf{q}^{*} \quad$ Alpha

$3.49978 \quad 0.05$ 


\begin{tabular}{|l|r|r|r|r|r|r|r|}
\hline Abs(Dif)-LSD & $\mathbf{9 0 : 1 0}$ & $\mathbf{7 0 : 3 0}$ & $\mathbf{5 0 : 5 0}$ & PDO & TCP & ELASTIN & media \\
\hline $90: 10$ & -3.4694 & -3.4548 & -3.1484 & -3.0844 & -1.7768 & -1.2854 & 2.4512 \\
\hline $70: 30$ & -3.4548 & -3.4694 & -3.1631 & -3.0991 & -1.7914 & -1.3001 & 2.4365 \\
\hline $50: 50$ & -3.1484 & -3.1631 & -3.4694 & -3.4054 & -2.0978 & -1.6064 & 2.1302 \\
\hline PDO & -3.0844 & -3.0991 & -3.4054 & -3.4694 & -2.1618 & -1.6704 & 2.0662 \\
\hline TCP & -1.7768 & -1.7914 & -2.0978 & -2.1618 & -3.4694 & -2.9781 & 0.7585 \\
\hline ELASTIN & -1.2854 & -1.3001 & -1.6064 & -1.6704 & -2.9781 & -3.4694 & 0.2672 \\
\hline media & 2.4512 & 2.4365 & 2.1302 & 2.0662 & 0.7585 & 0.2672 & -6.0092 \\
\hline
\end{tabular}

Positive values show pairs of means that are significantly different.

\begin{tabular}{|c|c|c|}
\hline Level & & Mean \\
\hline $90: 10$ & A & 8.1006667 \\
\hline $70: 30$ & A & 8.0860000 \\
\hline $50: 50$ & A & 7.7796667 \\
\hline PDO & A & 7.7156667 \\
\hline TCP & A & 6.4080000 \\
\hline ELASTIN & A & 5.9166667 \\
\hline media & & 0.74 \\
\hline
\end{tabular}

Levels not connected by same letter are significantly different.

$\begin{array}{llrr}\text { Level } & \text { - Level } & \text { Difference } & \text { Lower CL } \\ \text { 90:10 } & \text { media } & 7.357667 & 2.45115 \\ 70: 30 & \text { media } & 7.343000 & 2.43649 \\ \text { 50:50 } & \text { media } & 7.036667 & 2.13015 \\ \text { PDO } & \text { media } & 6.972667 & 2.06615 \\ \text { TCP } & \text { media } & 5.665000 & 0.75849 \\ \text { ELASTIN } & \text { media } & 5.173667 & 0.26715 \\ \text { 90:10 } & \text { ELASTIN } & 2.184000 & -1.28543 \\ 70: 30 & \text { ELASTIN } & 2.169333 & -1.30010 \\ \text { 50:50 } & \text { ELASTIN } & 1.863000 & -1.60643 \\ \text { PDO } & \text { ELASTIN } & 1.799000 & -1.67043 \\ 90: 10 & \text { TCP } & 1.692667 & -1.77676 \\ 70: 30 & \text { TCP } & 1.678000 & -1.79143 \\ 50: 50 & \text { TCP } & 1.371667 & -2.09776 \\ \text { PDO } & \text { TCP } & 1.307667 & -2.16176 \\ \text { TCP } & \text { ELASTIN } & 0.491333 & -2.97810 \\ 90: 10 & \text { PDO } & 0.385000 & -3.08443 \\ 70: 30 & \text { PDO } & 0.370333 & -3.09910 \\ 90: 10 & 50: 50 & 0.321000 & -3.14843 \\ 70: 30 & 50: 50 & 0.306333 & -3.16310 \\ 50: 50 & \text { PDO } & 0.064000 & -3.40543 \\ 90: 10 & 70: 30 & 0.014667 & -3.45476\end{array}$

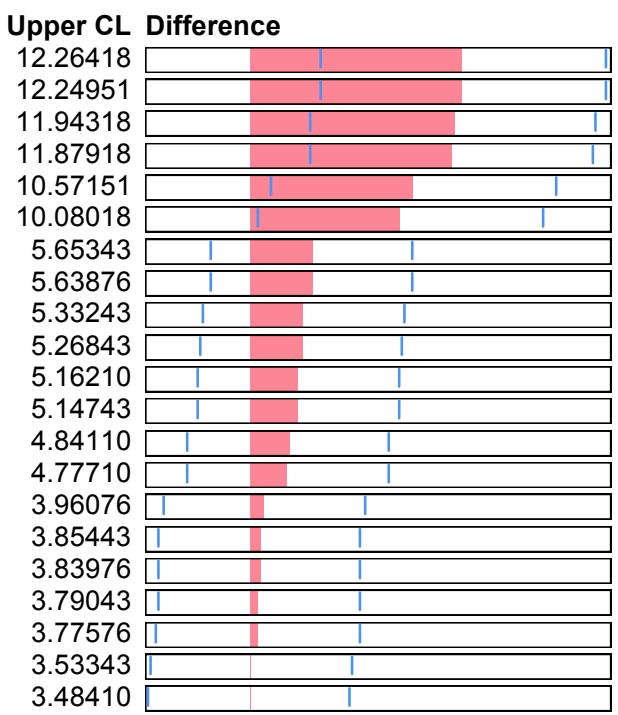


Oneway Analysis of Day 28 By PDO:elastin scaffolds for VEGF secretion

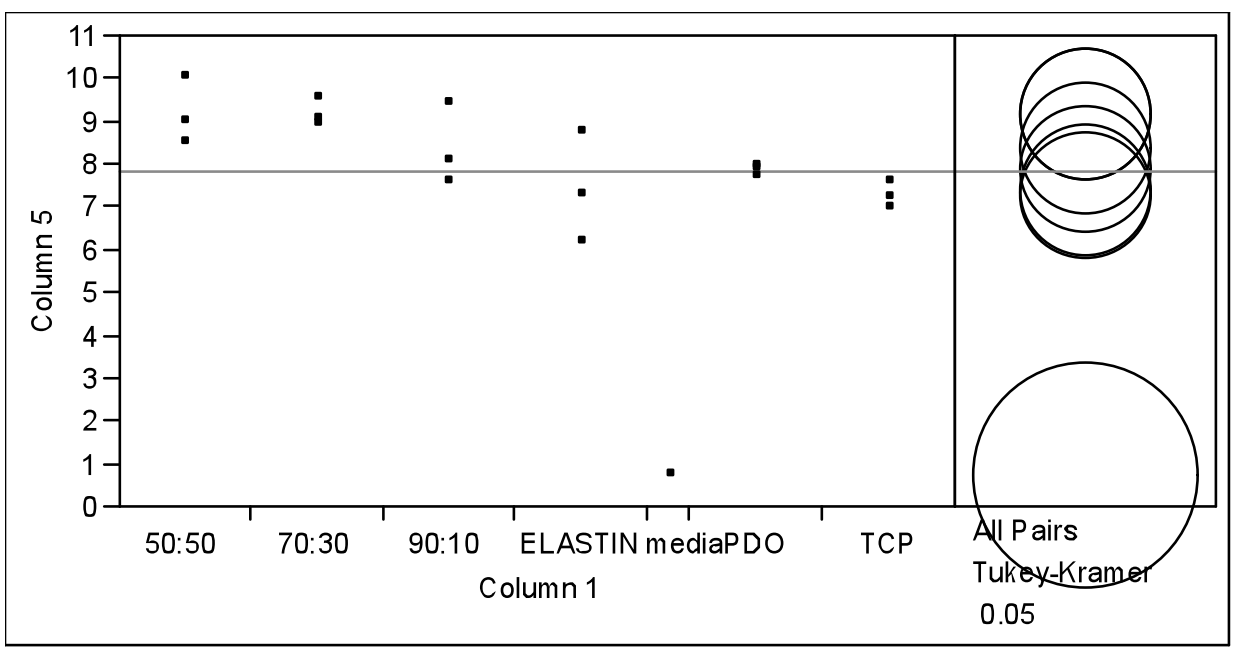

\section{Means Comparisons}

Comparisons for all pairs using Tukey-Kramer HSD

$\begin{array}{rr}\mathbf{q}^{*} & \text { Alpha } \\ 3.49978 & 0.05\end{array}$

\begin{tabular}{|l|r|r|r|r|r|r|r|}
\hline Abs(Dif)-LSD & $\mathbf{7 0 : 3 0}$ & $\mathbf{5 0 : 5 0}$ & $\mathbf{9 0 : 1 0}$ & PDO & ELASTIN & TCP & media \\
\hline $70: 30$ & -2.1492 & -2.1306 & -1.3342 & -0.8182 & -0.3496 & -0.2162 & 5.3965 \\
\hline $50: 50$ & -2.1306 & -2.1492 & -1.3529 & -0.8369 & -0.3682 & -0.2349 & 5.3779 \\
\hline $90: 10$ & -1.3342 & -1.3529 & -2.1492 & -1.6332 & -1.1646 & -1.0312 & 4.5815 \\
\hline PDO & -0.8182 & -0.8369 & -1.6332 & -2.1492 & -1.6806 & -1.5472 & 4.0655 \\
\hline ELASTIN & -0.3496 & -0.3682 & -1.1646 & -1.6806 & -2.1492 & -2.0159 & 3.5969 \\
\hline TCP & -0.2162 & -0.2349 & -1.0312 & -1.5472 & -2.0159 & -2.1492 & 3.4635 \\
\hline media & 5.3965 & 5.3779 & 4.5815 & 4.0655 & 3.5969 & 3.4635 & -3.7226 \\
\hline
\end{tabular}

Positive values show pairs of means that are significantly different.

\begin{tabular}{|c|c|c|}
\hline Level & & Mean \\
\hline $70: 30$ & A & 9.1790000 \\
\hline $50: 50$ & A & 9.1603333 \\
\hline $90: 10$ & A & 8.3640000 \\
\hline PDO & A & 7.8480000 \\
\hline ELASTIN & A & 7.3793333 \\
\hline TCP & A & 7.2460000 \\
\hline media & & 0.7430000 \\
\hline
\end{tabular}

Levels not connected by same letter are significantly different.

$\begin{array}{llrr}\text { Level } & \text { - Level } & \text { Difference } & \text { Lower CL } \\ \text { 70:30 } & \text { media } & 8.436000 & 5.39654 \\ \text { 50:50 } & \text { media } & 8.417333 & 5.37788 \\ \text { 90:10 } & \text { media } & 7.621000 & 4.58154 \\ \text { PDO } & \text { media } & 7.105000 & 4.06554 \\ \text { ELASTIN } & \text { media } & 6.636333 & 3.59688 \\ \text { TCP } & \text { media } & 6.503000 & 3.46354 \\ 70: 30 & \text { TCP } & 1.933000 & -0.21622 \\ 50: 50 & \text { TCP } & 1.914333 & -0.23489 \\ 70: 30 & \text { ELASTIN } & 1.799667 & -0.34955 \\ 50: 50 & \text { ELASTIN } & 1.781000 & -0.36822\end{array}$

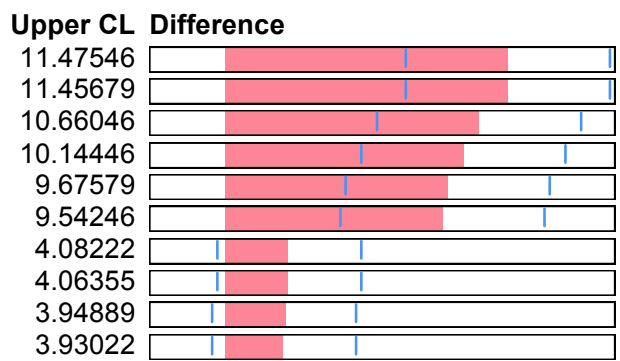




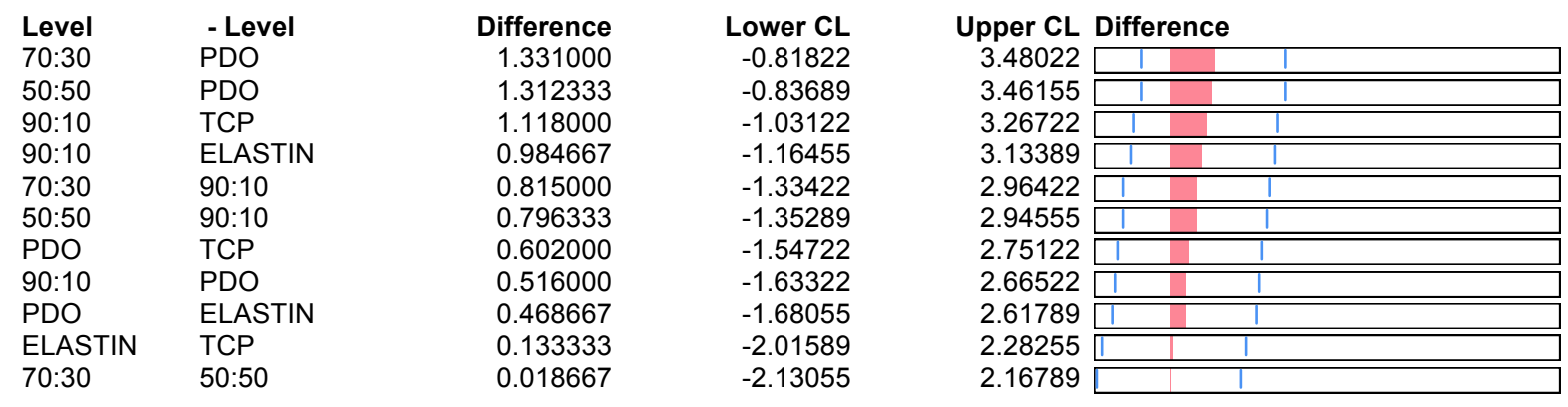

Fit $Y$ by $X$ Group

Oneway Analysis of Day 7 By PDO:elastin scaffolds for aFGF secretion

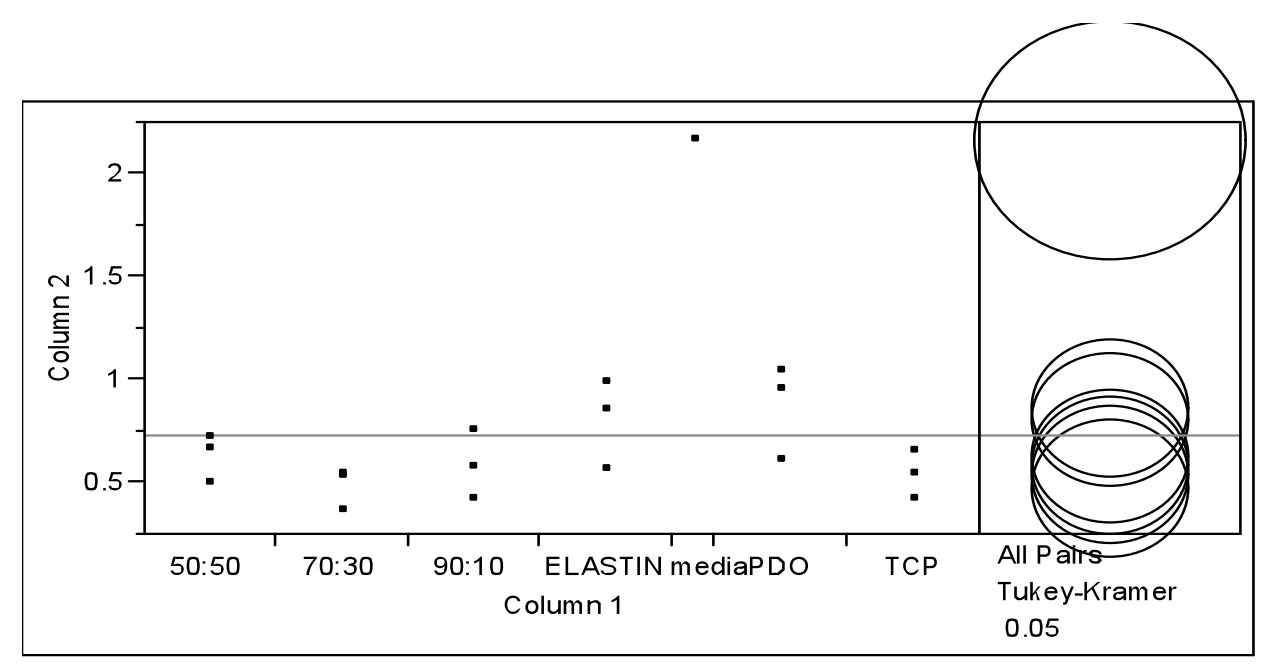

\section{Means Comparisons \\ Comparisons for all pairs using Tukey-Kramer HSD \\ $q^{*}$ \\ Alpha \\ $3.49978 \quad 0.05$}

\begin{tabular}{|l|r|r|r|r|r|r|r|}
\hline Abs(Dif)-LSD & media & PDO & ELASTIN & $\mathbf{5 0 : 5 0}$ & $\mathbf{9 0 : 1 0}$ & TCP & $\mathbf{7 0 : 3 0}$ \\
\hline media & -0.8157 & 0.6320 & 0.6953 & 0.8730 & 0.9147 & 0.9567 & 1.0207 \\
\hline PDO & 0.6320 & -0.4709 & -0.4076 & -0.2299 & -0.1883 & -0.1463 & -0.0823 \\
\hline ELASTIN & 0.6953 & -0.4076 & -0.4709 & -0.2933 & -0.2516 & -0.2096 & -0.1456 \\
\hline $50: 50$ & 0.8730 & -0.2299 & -0.2933 & -0.4709 & -0.4293 & -0.3873 & -0.3233 \\
\hline $90: 10$ & 0.9147 & -0.1883 & -0.2516 & -0.4293 & -0.4709 & -0.4289 & -0.3649 \\
\hline TCP & 0.9567 & -0.1463 & -0.2096 & -0.3873 & -0.4289 & -0.4709 & -0.4069 \\
\hline $70: 30$ & 1.0207 & -0.0823 & -0.1456 & -0.3233 & -0.3649 & -0.4069 & -0.4709 \\
\hline
\end{tabular}


Positive values show pairs of means that are significantly different.

$\begin{array}{lrrr}\text { Level } & & \text { Mean } \\ \text { media } & \text { A } & & 2.1610000 \\ \text { PDO } & & \text { B } & 0.8630000 \\ \text { ELASTIN } & \text { B } & 0.7996667 \\ 50: 50 & \text { B } & 0.6220000 \\ 90: 10 & \text { B } & 0.5803333 \\ \text { TCP } & \text { B } & 0.5383333 \\ 70: 30 & \text { B } & 0.4743333\end{array}$

Levels not connected by same letter are significantly different.

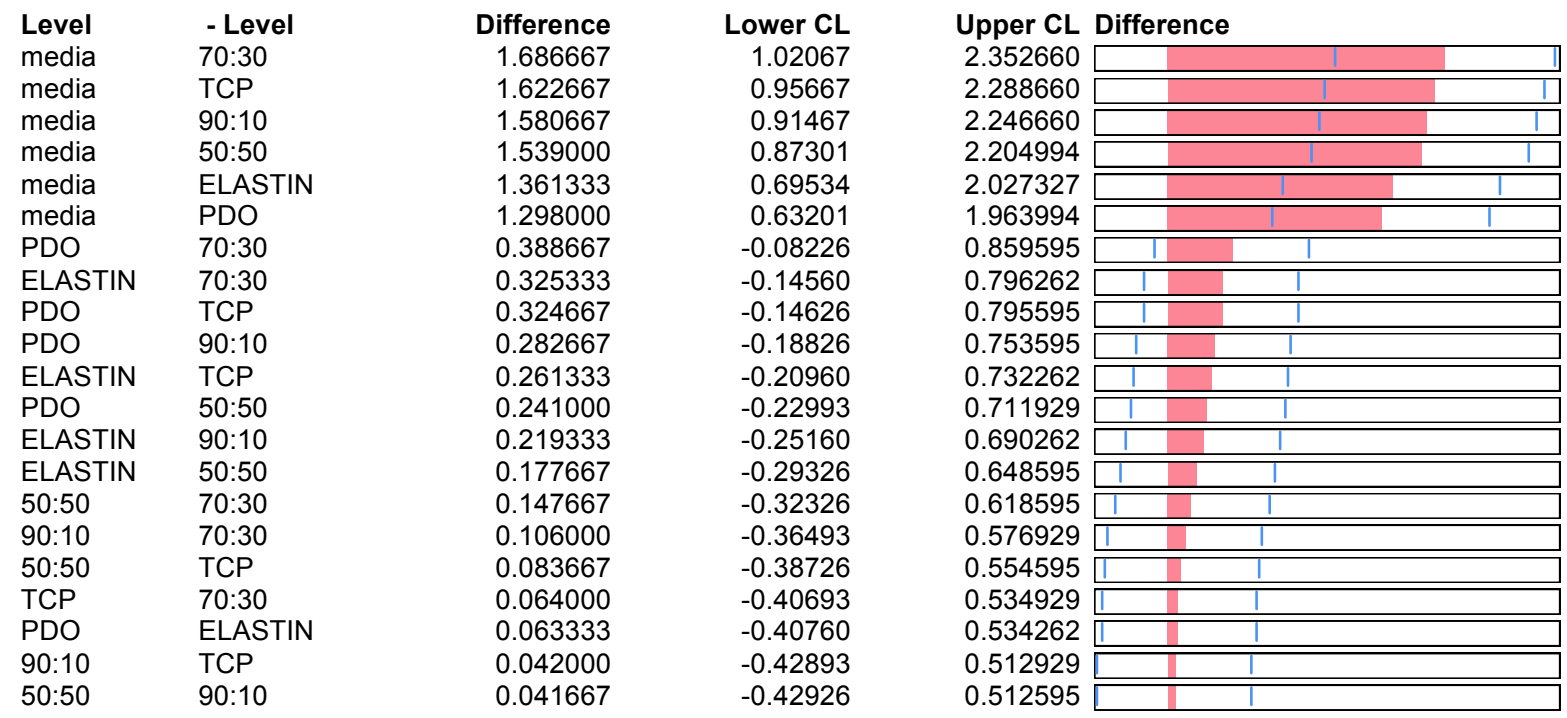

Oneway Analysis of Day 14 By PDO:elastin scaffolds for aFGF secretion

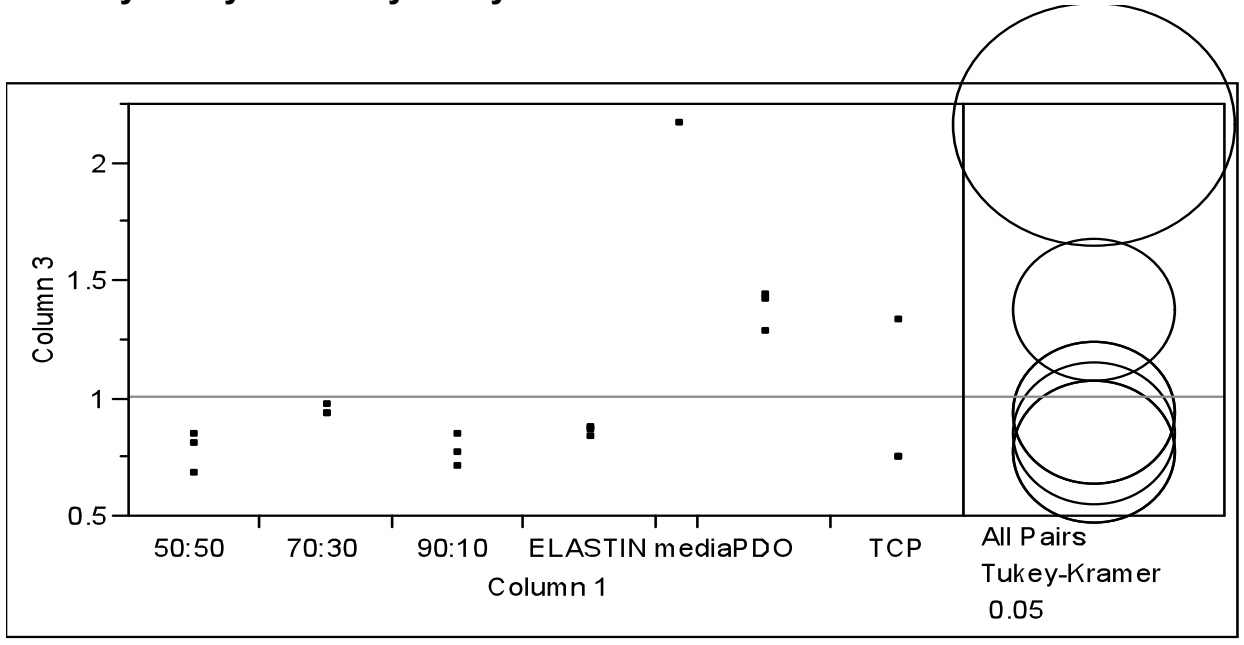

Means Comparisons

Comparisons for all pairs using Tukey-Kramer HSD

$\begin{array}{rr}\mathbf{q}^{*} & \text { Alpha } \\ 3.49978 & 0.05\end{array}$ 


\begin{tabular}{|l|r|r|r|r|r|r|r|}
\hline Abs(Dif)-LSD & media & PDO & $\mathbf{7 0 : 3 0}$ & TCP & ELASTIN & $\mathbf{5 0 : 5 0}$ & $\mathbf{9 0 : 1 0}$ \\
\hline media & -0.73603 & 0.18304 & 0.62104 & 0.62304 & 0.70670 & 0.78970 & 0.79037 \\
\hline PDO & 0.18304 & -0.42495 & 0.01305 & 0.01505 & 0.09872 & 0.18172 & 0.18239 \\
\hline $70: 30$ & 0.62104 & 0.01305 & -0.42495 & -0.42295 & -0.33928 & -0.25628 & -0.25561 \\
\hline TCP & 0.62304 & 0.01505 & -0.42295 & -0.42495 & -0.34128 & -0.25828 & -0.25761 \\
\hline ELASTIN & 0.70670 & 0.09872 & -0.33928 & -0.34128 & -0.42495 & -0.34195 & -0.34128 \\
\hline $50: 50$ & 0.78970 & 0.18172 & -0.25628 & -0.25828 & -0.34195 & -0.42495 & -0.42428 \\
\hline $90: 10$ & 0.79037 & 0.18239 & -0.25561 & -0.25761 & -0.34128 & -0.42428 & -0.42495 \\
\hline
\end{tabular}

Positive values show pairs of means that are significantly different.

$\begin{array}{lrrrrr}\text { Level } & & & & \text { Mean } \\ \text { media } & \text { A } & & & 2.1610000 \\ \text { PDO } & & \text { B } & & 1.3770000 \\ 70: 30 & & & \text { C } & 0.9390000 \\ \text { TCP } & & & \text { C } & 0.9370000 \\ \text { ELASTIN } & & & \text { C } & 0.8533333 \\ 50: 50 & & & \text { C } & 0.7703333 \\ 90: 10 & & & \text { C } & 0.7696667\end{array}$

Levels not connected by same letter are significantly different.

$\begin{array}{llrr}\text { Level } & \text { - Level } & \text { Difference } & \text { Lower CL } \\ \text { media } & 90: 10 & 1.391333 & 0.790369 \\ \text { media } & 50: 50 & 1.390667 & 0.789702 \\ \text { media } & \text { ELASTIN } & 1.307667 & 0.706702 \\ \text { media } & \text { TCP } & 1.224000 & 0.623036 \\ \text { media } & 70: 30 & 1.222000 & 0.621036 \\ \text { media } & \text { PDO } & 0.784000 & 0.183036 \\ \text { PDO } & 90: 10 & 0.607333 & 0.182387 \\ \text { PDO } & 50: 50 & 0.606667 & 0.181721 \\ \text { PDO } & \text { ELASTIN } & 0.523667 & 0.098721 \\ \text { PDO } & \text { TCP } & 0.440000 & 0.015054 \\ \text { PDO } & 70: 30 & 0.438000 & 0.013054 \\ 70: 30 & 90: 10 & 0.169333 & -0.255613 \\ 70: 30 & 50: 50 & 0.168667 & -0.256279 \\ \text { TCP } & 90: 10 & 0.167333 & -0.257613 \\ \text { TCP } & 50: 50 & 0.166667 & -0.258279 \\ 70: 30 & \text { ELASTIN } & 0.085667 & -0.339279 \\ \text { ELASTIN } & 90: 10 & 0.083667 & -0.341279 \\ \text { TCP } & \text { ELASTIN } & 0.083667 & -0.341279 \\ \text { ELASTIN } & 50: 50 & 0.083000 & -0.341946 \\ 70: 30 & \text { TCP } & 0.002000 & -0.422946 \\ 50: 50 & 90: 10 & 0.000667 & -0.424279\end{array}$

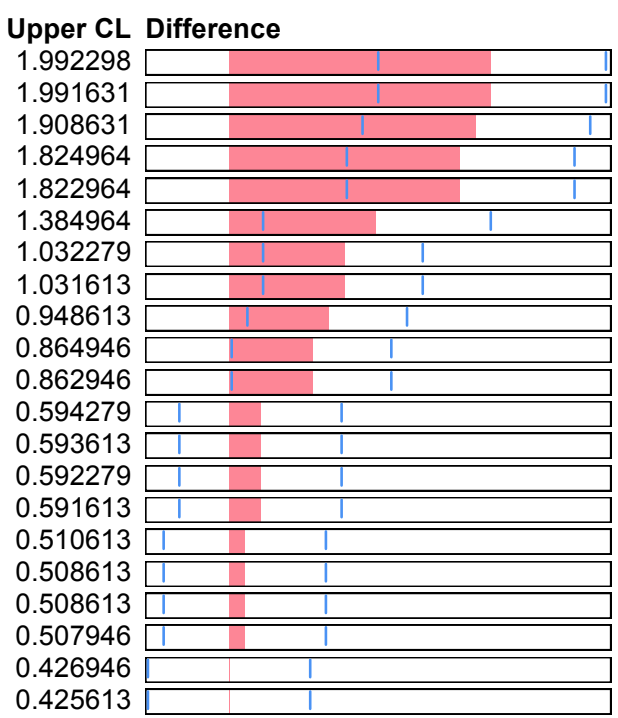


Oneway Analysis of Day 21 By PDO:elastin scaffolds for aFGF secretion

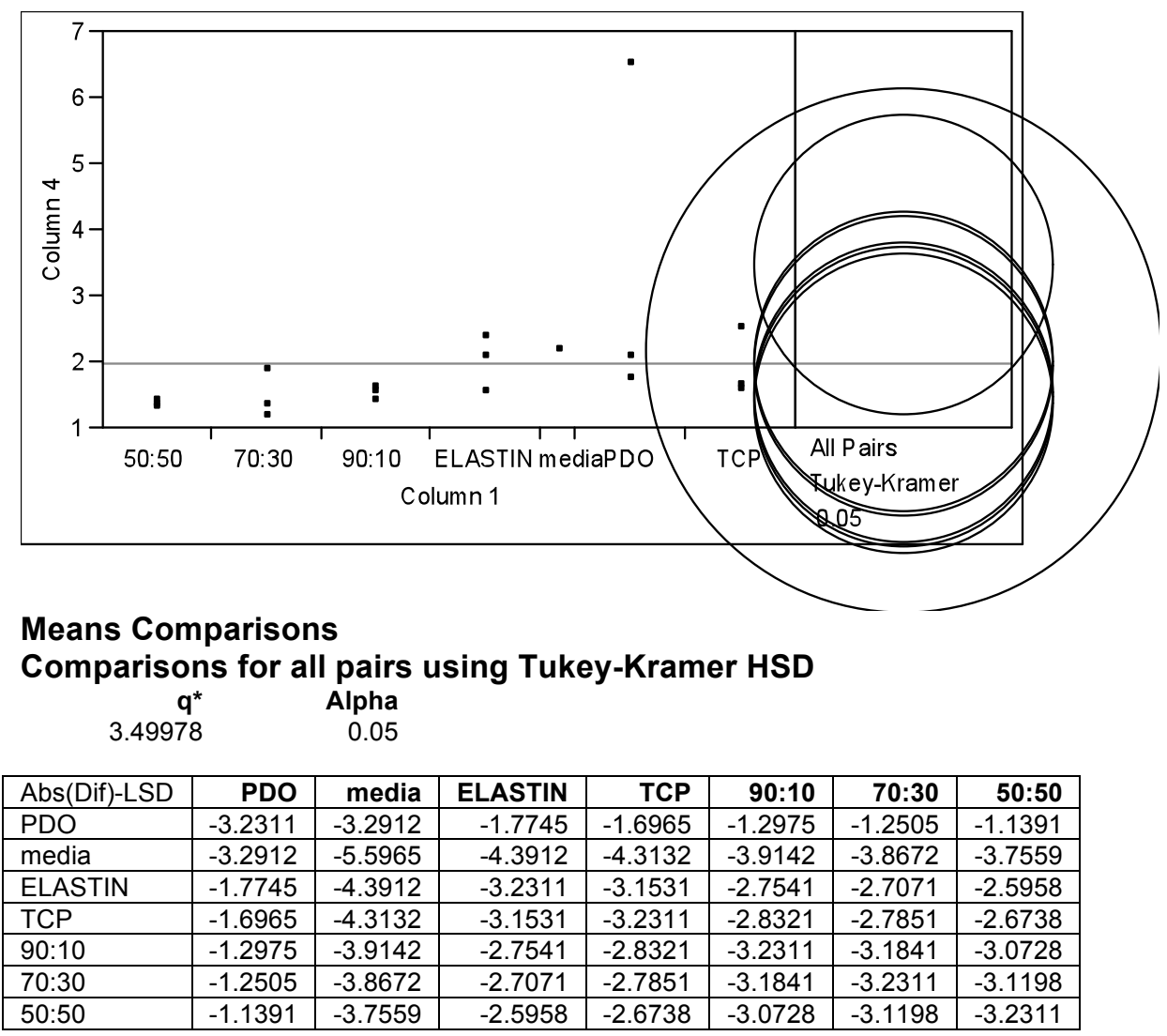

Positive values show pairs of means that are significantly different.

$\begin{array}{llr}\text { Level } & & \text { Mean } \\ \text { PDO } & \text { A } & 3.4393333 \\ \text { media } & \text { A } & 2.1610000 \\ \text { ELASTIN } & \text { A } & 1.9826667 \\ \text { TCP } & \text { A } & 1.9046667 \\ 90: 10 & \text { A } & 1.5056667 \\ 70: 30 & \text { A } & 1.4586667 \\ 50: 50 & \text { A } & 1.3473333\end{array}$

Levels not connected by same letter are significantly different.

$\begin{array}{llrr}\text { Level } & - \text { Level } & \text { Difference } & \text { Lower CL } \\ \text { PDO } & 50: 50 & 2.092000 & -1.13914 \\ \text { PDO } & 70: 30 & 1.980667 & -1.25047 \\ \text { PDO } & 90: 10 & 1.933667 & -1.29747 \\ \text { PDO } & \text { TCP } & 1.534667 & -1.69647 \\ \text { PDO } & \text { ELASTIN } & 1.456667 & -1.77447 \\ \text { PDO } & \text { media } & 1.278333 & -3.29119 \\ \text { media } & 50: 50 & 0.813667 & -3.75585 \\ \text { media } & 70: 30 & 0.702333 & -3.86719 \\ \text { media } & 90: 10 & 0.655333 & -3.91419 \\ \text { ELASTIN } & 50: 50 & 0.635333 & -2.59580 \\ \text { TCP } & 50: 50 & 0.557333 & -2.67380 \\ \text { ELASTIN } & 70: 30 & 0.524000 & -2.70714\end{array}$

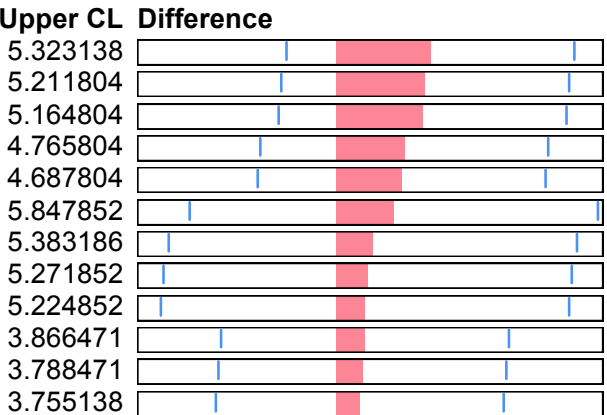




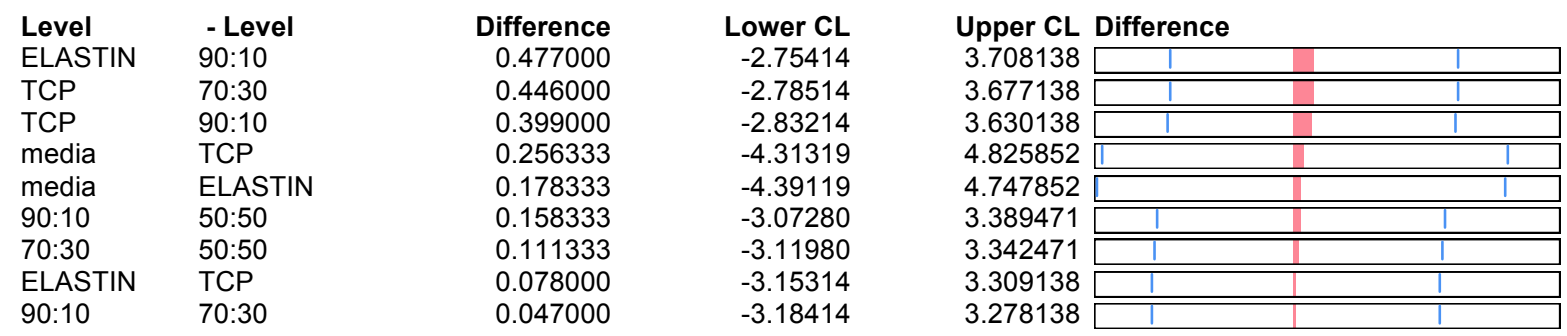

\section{Oneway Analysis of Day 28 By PDO:elastin scaffolds for aFGF secretion}

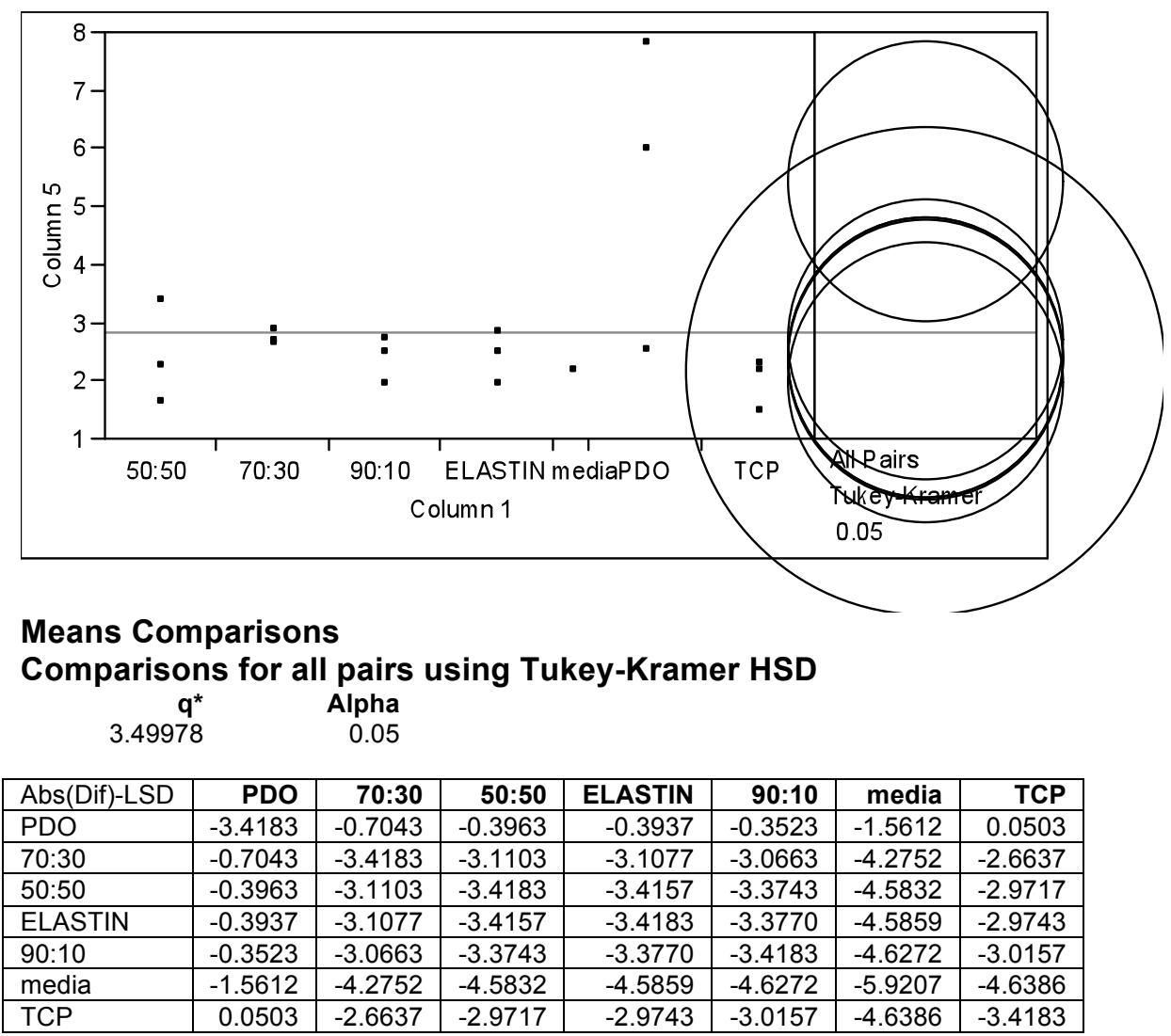

Positive values show pairs of means that are significantly different.

$\begin{array}{lllr}\text { Level } & & & \text { Mean } \\ \text { PDO } & \text { A } & & 5.4340000 \\ 70: 30 & \text { A } & \text { B } & 2.7200000 \\ 50: 50 & \text { A } & \text { B } & 2.4120000 \\ \text { ELASTIN } & \text { A } & \text { B } & 2.4093333 \\ 90: 10 & \text { A } & \text { B } & 2.3680000 \\ \text { media } & \text { A } & \text { B } & 2.1610000 \\ \text { TCP } & & \text { B } & 1.9653333\end{array}$

Levels not connected by same letter are significantly different.

$\begin{array}{llrrr}\text { Level } & \text { - Level } & \text { Difference } & \text { Lower CL } & \text { Upper CL Difference } \\ \text { PDO } & \text { TCP } & 3.468667 & 0.05034 & 6.886989\end{array}$

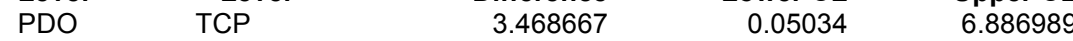




$\begin{array}{ll}\text { Level } & \text { - Level } \\ \text { PDO } & \text { media } \\ \text { PDO } & 90: 10 \\ \text { PDO } & \text { ELASTIN } \\ \text { PDO } & 50: 50 \\ \text { PDO } & 70: 30 \\ 70: 30 & \text { TCP } \\ 70: 30 & \text { media } \\ \text { 50:50 } & \text { TCP } \\ \text { ELASTIN } & \text { TCP } \\ \text { 90:10 } & \text { TCP } \\ \text { 70:30 } & 90: 10 \\ \text { 70:30 } & \text { ELASTIN } \\ \text { 70:30 } & 50: 50 \\ \text { 50:50 } & \text { media } \\ \text { ELASTIN } & \text { media } \\ \text { 90:10 } & \text { media } \\ \text { media } & \text { TCP } \\ \text { 50:50 } & 90: 10 \\ \text { ELASTIN } & 90: 10 \\ \text { 50:50 } & \text { ELASTIN }\end{array}$

$\begin{array}{rr}\text { Difference } & \text { Lower CL } \\ 3.273000 & -1.56124 \\ 3.066000 & -0.35232 \\ 3.024667 & -0.39366 \\ 3.022000 & -0.39632 \\ 2.714000 & -0.70432 \\ 0.754667 & -2.66366 \\ 0.559000 & -4.27524 \\ 0.446667 & -2.97166 \\ 0.444000 & -2.97432 \\ 0.402667 & -3.01566 \\ 0.352000 & -3.06632 \\ 0.310667 & -3.10766 \\ 0.308000 & -3.11032 \\ 0.251000 & -4.58324 \\ 0.248333 & -4.58590 \\ 0.207000 & -4.62724 \\ 0.195667 & -4.63857 \\ 0.044000 & -3.37432 \\ 0.041333 & -3.37699 \\ 0.002667 & -3.41566\end{array}$

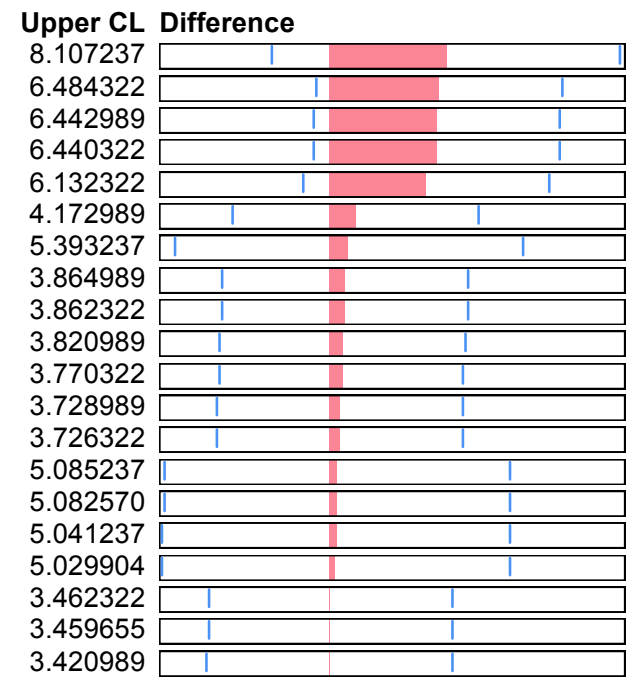


Fit $Y$ by $X$ Group

Oneway Analysis of day 7 by PDO:Elastin scaffolds for TGF- $\beta 1$ secretion

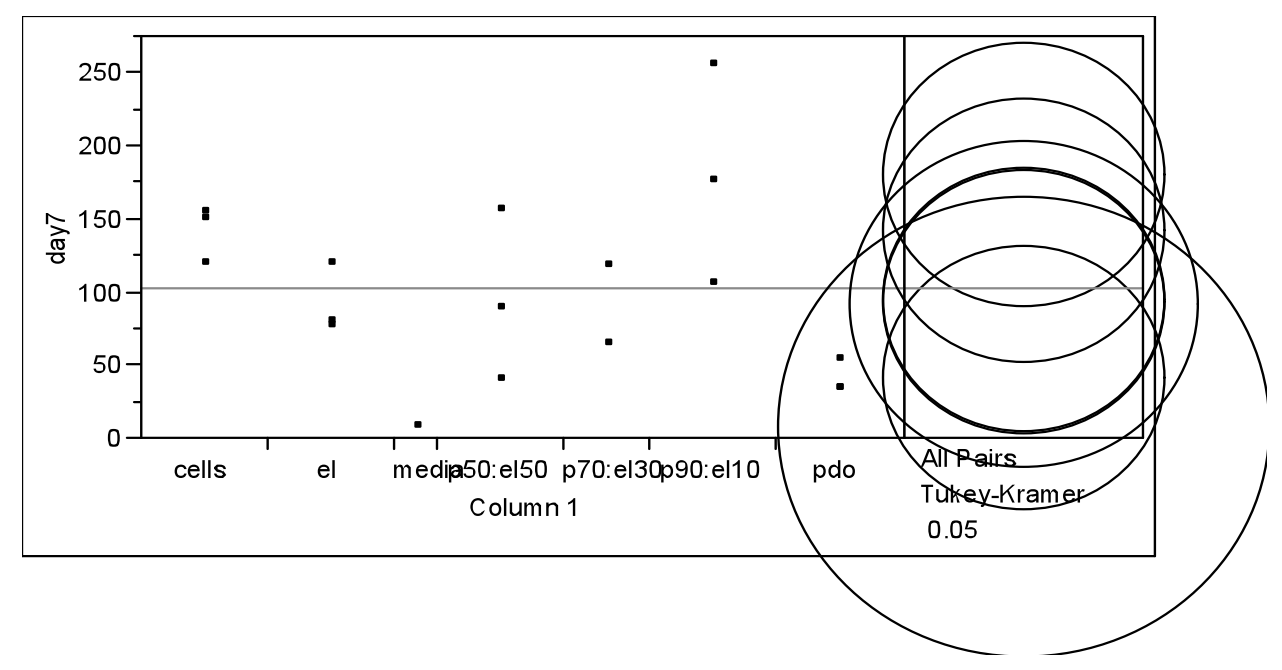

Means Comparisons

Comparisons for all pairs using Tukey-Kramer HSD

$q^{*} \quad$ Alpha

$3.55539 \quad 0.05$

\begin{tabular}{|l|r|r|r|r|r|r|r|}
\hline Abs(Dif)-LSD & p90:el10 & cells & p50:el50 & el & p70:el30 & pdo & media \\
\hline p90:el10 & -128.50 & -90.95 & -43.96 & -41.38 & -56.04 & 10.35 & -11.09 \\
\hline cells & -90.95 & -128.50 & -81.52 & -78.93 & -93.60 & -27.21 & -48.65 \\
\hline p50:el50 & -43.96 & -81.52 & -128.50 & -125.92 & -140.58 & -74.20 & -95.64 \\
\hline el & -41.38 & -78.93 & -125.92 & -128.50 & -143.17 & -76.78 & -98.22 \\
\hline p70:el30 & -56.04 & -93.60 & -140.58 & -143.17 & -157.38 & -92.45 & -109.75 \\
\hline pdo & 10.35 & -27.21 & -74.20 & -76.78 & -92.45 & -128.50 & -149.94 \\
\hline media & -11.09 & -48.65 & -95.64 & -98.22 & -109.75 & -149.94 & -222.58 \\
\hline
\end{tabular}

Positive values show pairs of means that are significantly different.

$\begin{array}{llrr}\text { Level } & & & \text { Mean } \\ \text { p90:el10 } & \text { A } & & 178.93900 \\ \text { cells } & \text { A } & \text { B } & 141.38333 \\ \text { p50:el50 } & \text { A } & \text { B } & 94.39567 \\ \text { el } & \text { A } & \text { B } & 91.81267 \\ \text { p70:el30 } & \text { A } & \text { B } & 91.30700 \\ \text { pdo } & & \text { B } & 40.08867 \\ \text { media } & \text { A } & \text { B } & 8.30000\end{array}$

Levels not connected by same letter are significantly different.

$\begin{array}{llrr}\text { Level } & \text { - Level } & \text { Difference } & \text { Lower CL } \\ \text { p90:el10 } & \text { media } & 170.6390 & -11.093 \\ \text { p90:el10 } & \text { pdo } & 138.8503 & 10.346 \\ \text { cells } & \text { media } & 133.0833 & -48.649 \\ \text { cells } & \text { pdo } & 101.2947 & -27.210 \\ \text { p90:el10 } & \text { p70:el30 } & 87.6320 & -56.040 \\ \text { p90:el10 } & \text { el } & 87.1263 & -41.378 \\ \text { p50:el50 } & \text { media } & 86.0957 & -95.637 \\ \text { p90:el10 } & \text { p50:el50 } & 84.5433 & -43.961 \\ \text { el } & \text { media } & 83.5127 & -98.220\end{array}$

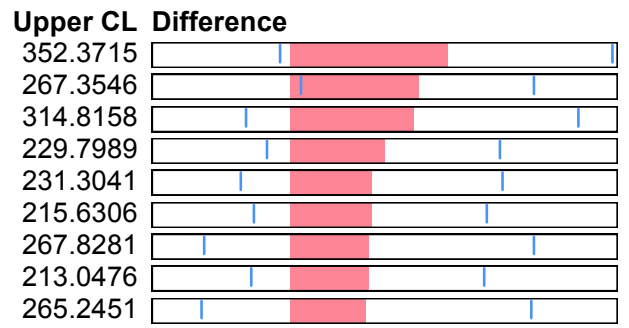




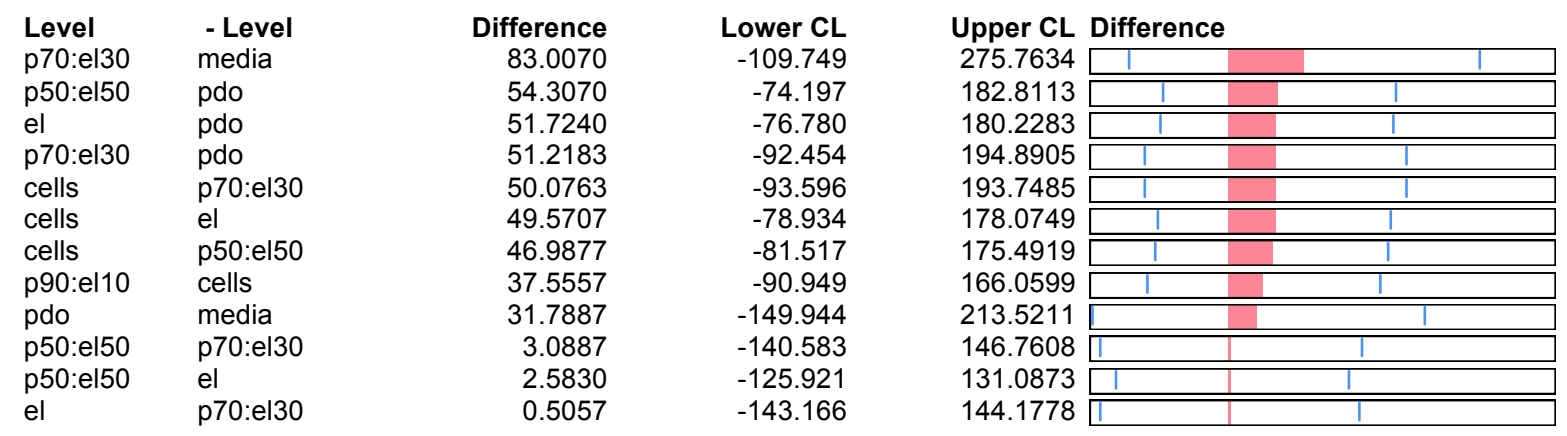

\section{Oneway Analysis of day 14 by PDO:elastin scaffolds for TGF- $\beta 1$ secretion}

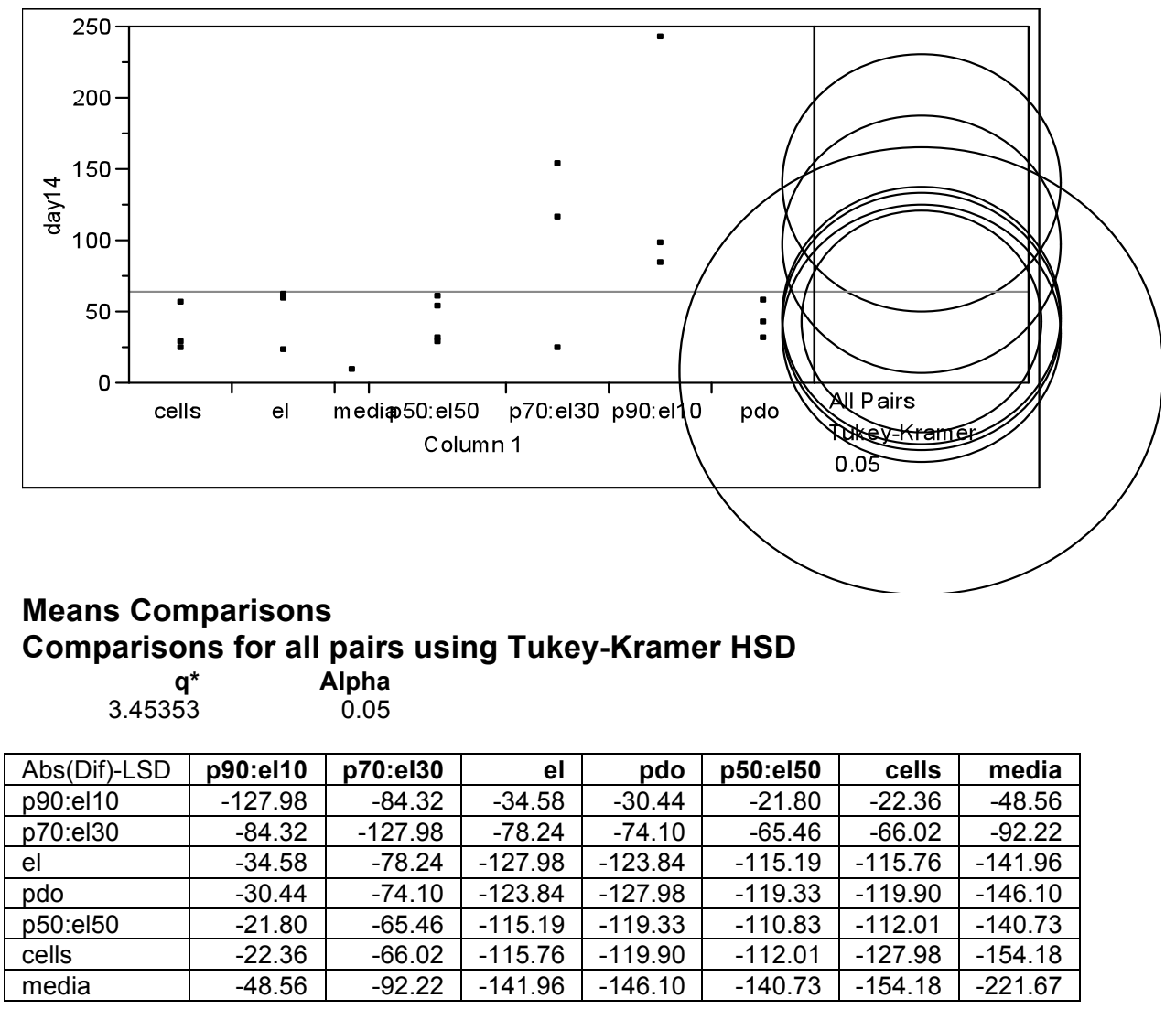

Positive values show pairs of means that are significantly different.

$\begin{array}{llr}\text { Level } & & \text { Mean } \\ \text { p90:el10 } & \text { A } & 140.72967 \\ \text { p70:el30 } & \text { A } & 97.06933 \\ \text { el } & \text { A } & 47.33267 \\ \text { pdo } & \text { A } & 43.19333 \\ \text { p50:el50 } & \text { A } & 42.81275 \\ \text { cells } & \text { A } & 35.11067 \\ \text { media } & \text { A } & 8.30000\end{array}$

Levels not connected by same letter are significantly different. 


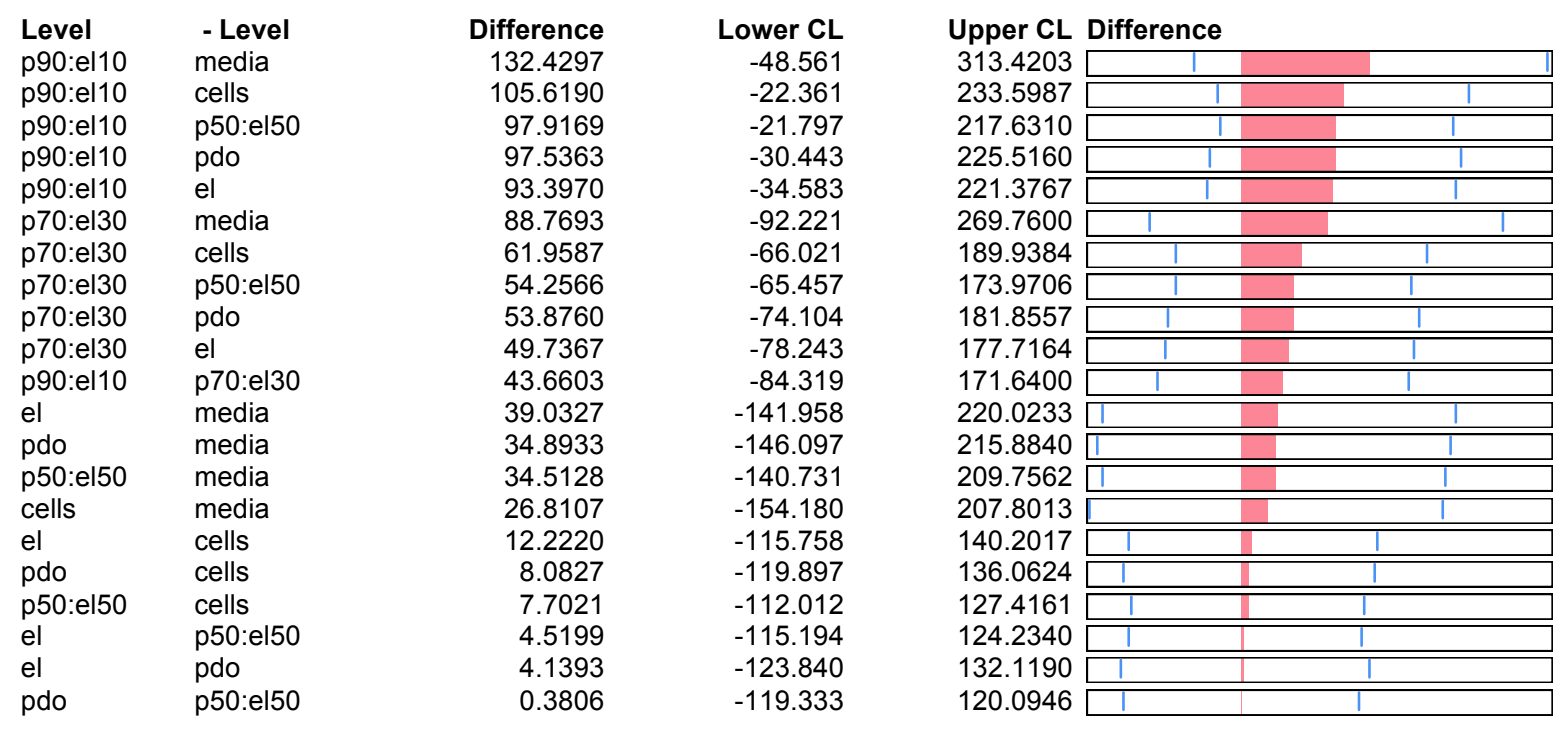

Oneway Analysis of day 21 by PDO:elastin scaffolds for TGF- $\beta 1$ secretion

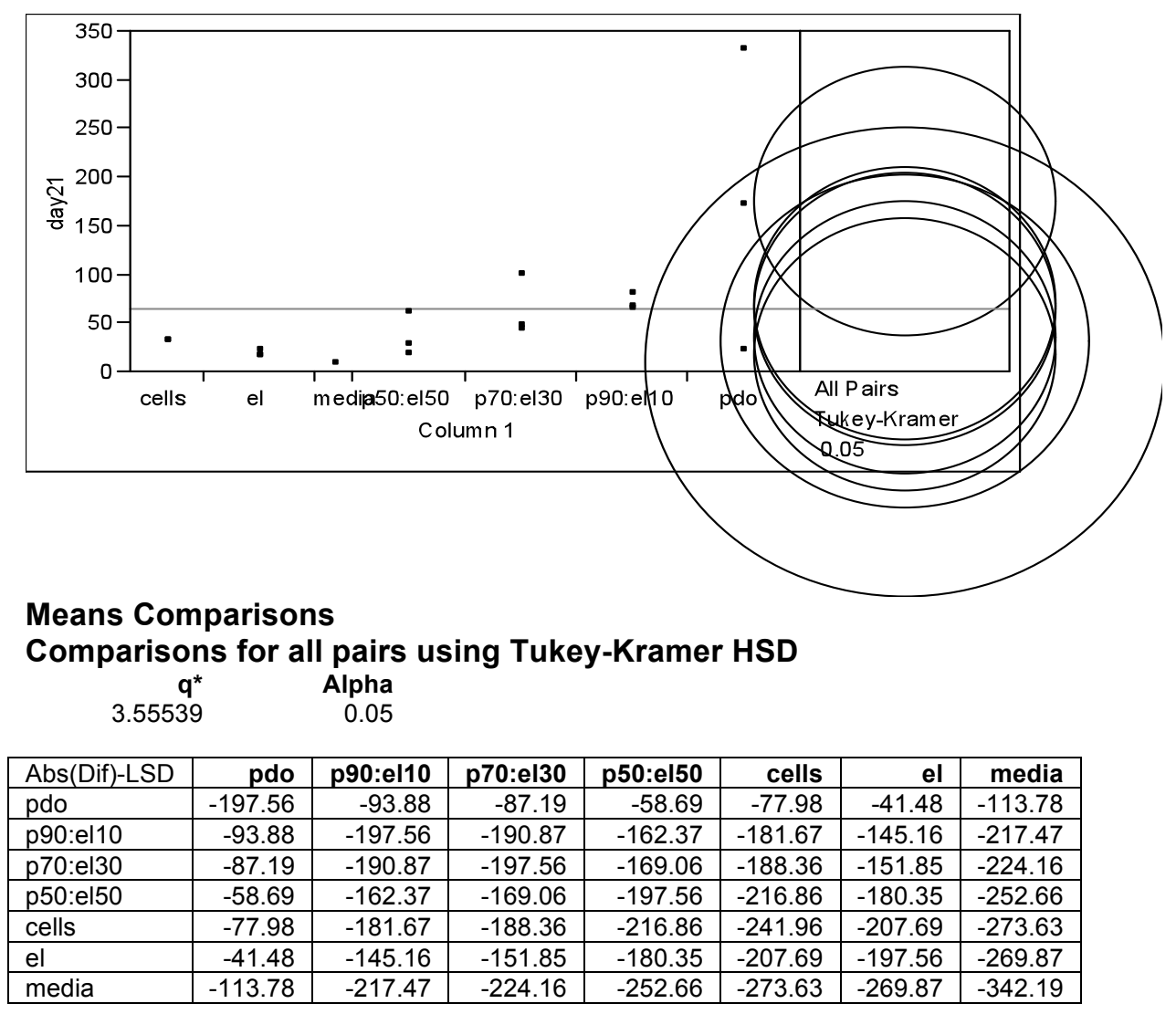

Positive values show pairs of means that are significantly different. 


$\begin{array}{llr}\text { Level } & & \text { Mean } \\ \text { pdo } & \text { A } & 173.91267 \\ \text { p90:el10 } & \text { A } & 70.22733 \\ \text { p70:el30 } & \text { A } & 63.53767 \\ \text { p50:el50 } & \text { A } & 35.03833 \\ \text { cells } & \text { A } & 31.01650 \\ \text { el } & \text { A } & 17.82833 \\ \text { media } & \text { A } & 8.30000\end{array}$

Levels not connected by same letter are significantly different.

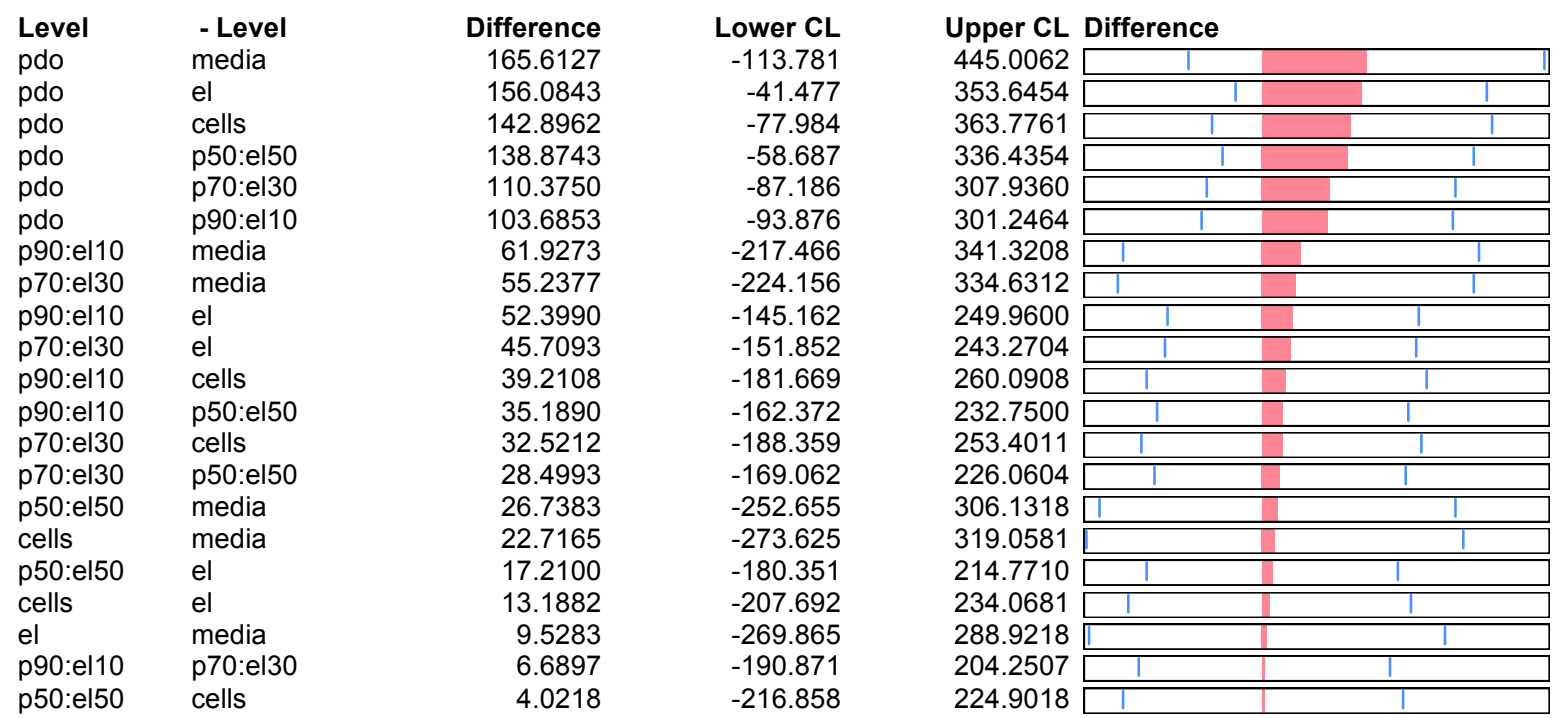

\section{Oneway Analysis of day 28 By PDO:elastin scaffolds for TGF- $\beta 1$ secretion}

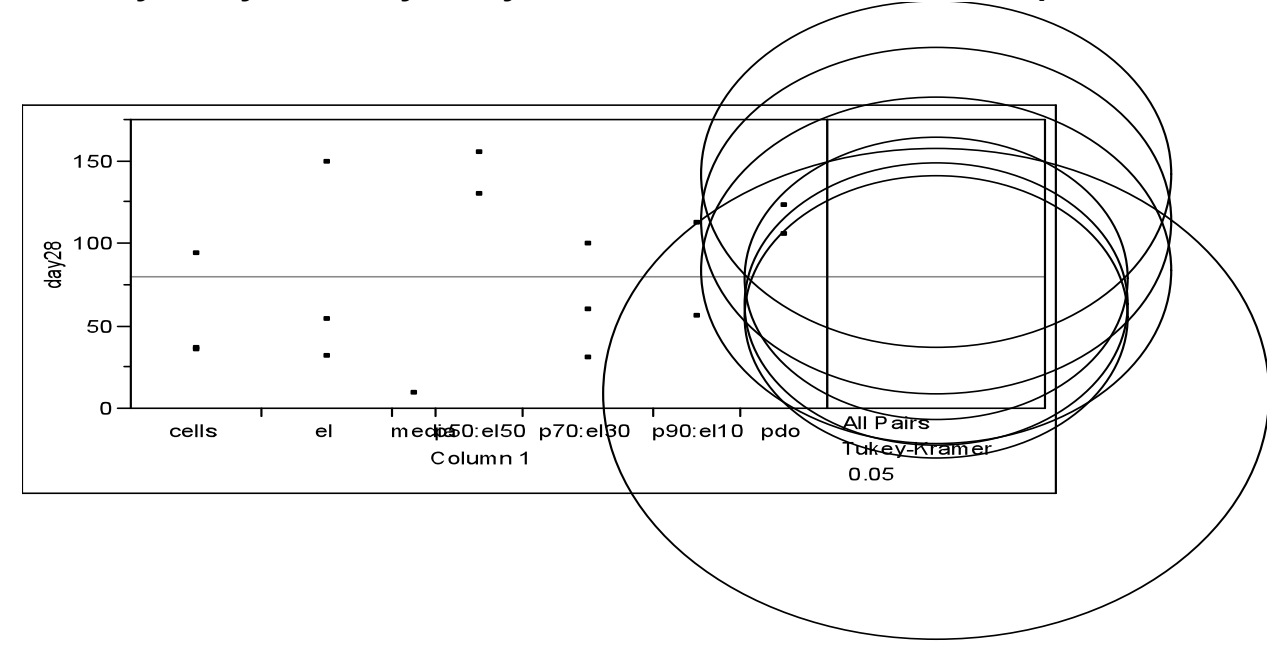

\section{Means Comparisons}

Comparisons for all pairs using Tukey-Kramer HSD

$$
\begin{array}{rr}
\mathbf{q}^{*} & \text { Alpha } \\
826 & 0.05
\end{array}
$$

\begin{tabular}{|l|r|r|r|r|r|r|r|}
\hline Abs(Dif)-LSD & p50:el50 & pdo & p90:el10 & el & p70:el30 & cells & media \\
\hline p50:el50 & -149.00 & -120.67 & -90.68 & -71.89 & -57.03 & -48.92 & -48.87 \\
\hline pdo & -120.67 & -149.00 & -119.01 & -100.23 & -85.36 & -77.25 & -77.20 \\
\hline p90:el10 & -90.68 & -119.01 & -149.00 & -130.22 & -115.35 & -107.24 & -107.19 \\
\hline el & -71.89 & -100.23 & -130.22 & -121.66 & -106.80 & -98.69 & -102.55 \\
\hline p70:el30 & -57.03 & -85.36 & -115.35 & -106.80 & -121.66 & -113.55 & -117.42
\end{tabular}


Positive values show pairs of means that are significantly different.

$\begin{array}{llr}\text { Level } & & \text { Mean } \\ \text { p50:el50 } & \text { A } & 141.92300 \\ \text { pdo } & \text { A } & 113.59200 \\ \text { p90:el10 } & \text { A } & 83.60000 \\ \text { el } & \text { A } & 77.79867 \\ \text { p70:el30 } & \text { A } & 62.93600 \\ \text { cells } & \text { A } & 54.82500 \\ \text { media } & \text { A } & 8.30000\end{array}$

Levels not connected by same letter are significantly different.

$\begin{array}{llrr}\text { Level } & \text { - Level } & \text { Difference } & \text { Lower CL } \\ \text { p50:el50 } & \text { media } & 133.6230 & -48.866 \\ \text { pdo } & \text { media } & 105.2920 & -77.197 \\ \text { p50:el50 } & \text { cells } & 87.0980 & -48.921 \\ \text { p50:el50 } & \text { p70:el30 } & 78.9870 & -57.032 \\ \text { p90:el10 } & \text { media } & 75.3000 & -107.189 \\ \text { el } & \text { media } & 69.4987 & -102.553 \\ \text { p50:el50 } & \text { el } & 64.1243 & -71.895 \\ \text { pdo } & \text { cells } & 58.7670 & -77.252 \\ \text { p50:el50 } & \text { p90:el10 } & 58.3230 & -90.678 \\ \text { p70:el30 } & \text { media } & 54.6360 & -117.416 \\ \text { pdo } & \text { p70:el30 } & 50.6560 & -85.363 \\ \text { cells } & \text { media } & 46.5250 & -125.527 \\ \text { pdo } & \text { el } & 35.7933 & -100.226 \\ \text { pdo } & \text { p90:el10 } & 29.9920 & -119.009 \\ \text { p90:el10 } & \text { cells } & 28.7750 & -107.244 \\ \text { p50:el50 } & \text { pdo } & 28.3310 & -120.670 \\ \text { el } & \text { cells } & 22.9737 & -98.685 \\ \text { p90:el10 } & \text { p70:el30 } & 20.6640 & -115.355 \\ \text { el } & \text { p70:el30 } & 14.8627 & -106.796 \\ \text { p70:el30 } & \text { cells } & 8.1110 & -113.548 \\ \text { p90:el10 } & \text { el } & 5.8013 & -130.218\end{array}$

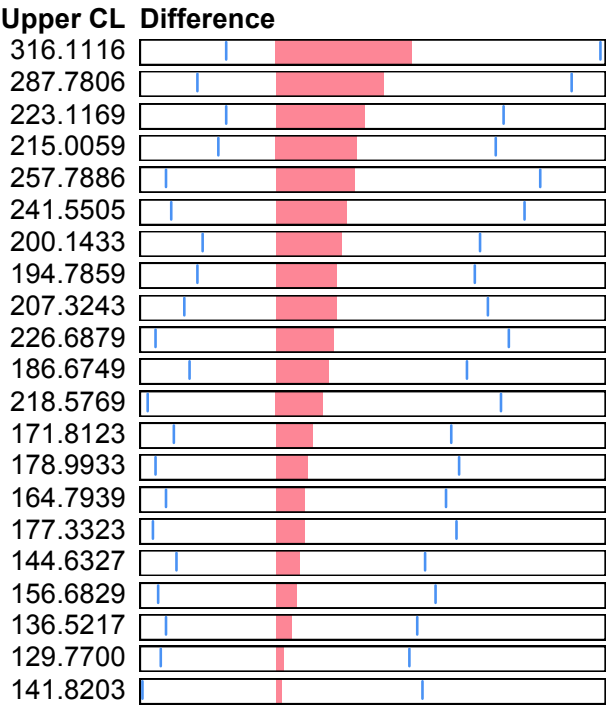


Fit $Y$ by $X$ Group

Oneway Analysis of Day 7 by PDO scaffolds of varying concentration for VEGF secretion

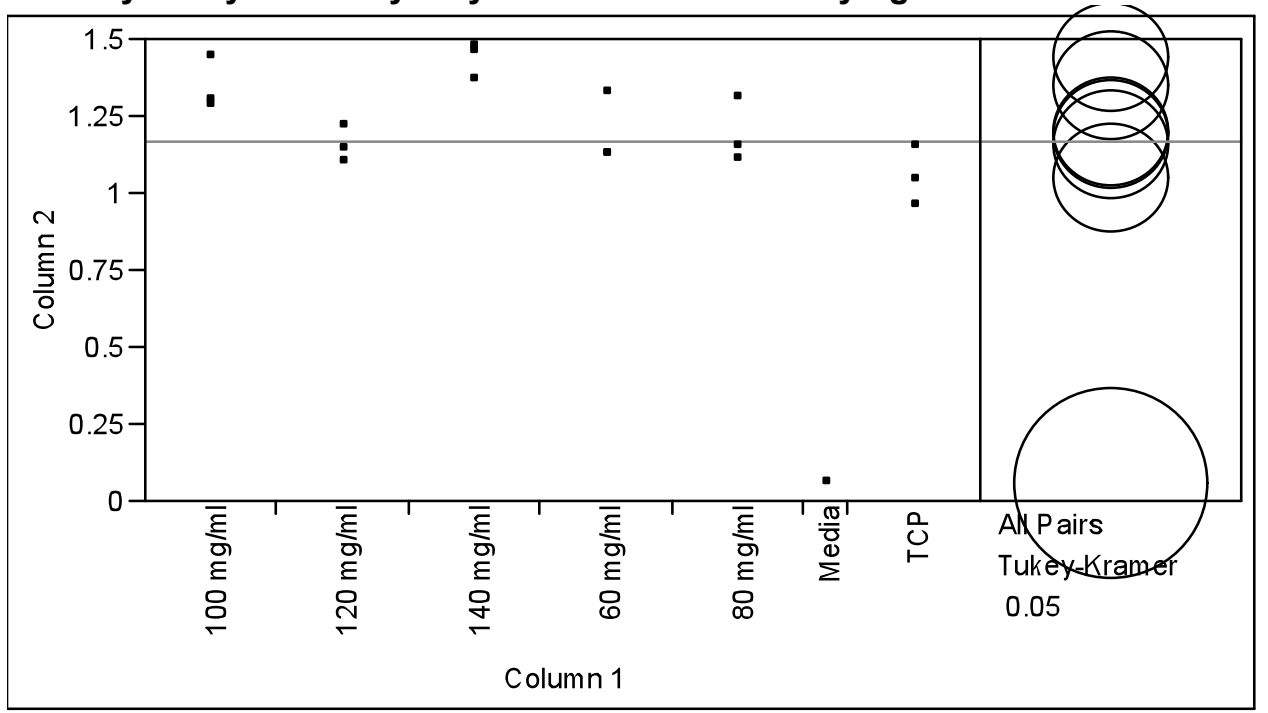

\section{Means Comparisons \\ Comparisons for all pairs using Tukey-Kramer HSD \\ $q^{*} \quad$ Alpha \\ $3.49978 \quad 0.05$}

\begin{tabular}{|l|r|r|r|r|r|r|r|}
\hline Abs(Dif)-LSD & $\mathbf{1 4 0} \mathbf{~} \mathbf{g} / \mathbf{m l}$ & $\mathbf{1 0 0} \mathbf{~} \mathbf{~ g} / \mathbf{m l}$ & $\mathbf{6 0} \mathbf{~} \mathbf{g} / \mathbf{m l}$ & $\mathbf{8 0} \mathbf{~} \mathbf{g} / \mathbf{m l}$ & $\mathbf{1 2 0} \mathbf{~} \mathbf{g} / \mathbf{m l}$ & TCP & $\mathbf{M e d i a}$ \\
\hline $140 \mathbf{~ m g} / \mathrm{ml}$ & -0.2537 & -0.1633 & -0.0127 & -0.0080 & 0.0290 & 0.1313 & 1.0149 \\
\hline $100 \mathbf{~ m g} / \mathrm{ml}$ & -0.1633 & -0.2537 & -0.1030 & -0.0983 & -0.0613 & 0.0410 & 0.9246 \\
\hline $60 \mathbf{~ m g} / \mathrm{ml}$ & -0.0127 & -0.1030 & -0.2537 & -0.2490 & -0.2120 & -0.1097 & 0.7739 \\
\hline $80 \mathbf{~ m g} / \mathrm{ml}$ & -0.0080 & -0.0983 & -0.2490 & -0.2537 & -0.2167 & -0.1143 & 0.7692 \\
\hline $120 \mathbf{~ m g} / \mathrm{ml}$ & 0.0290 & -0.0613 & -0.2120 & -0.2167 & -0.2537 & -0.1513 & 0.7322 \\
\hline TCP & 0.1313 & 0.0410 & -0.1097 & -0.1143 & -0.1513 & -0.2537 & 0.6299 \\
\hline Media & 1.0149 & 0.9246 & 0.7739 & 0.7692 & 0.7322 & 0.6299 & -0.4394 \\
\hline
\end{tabular}

Positive values show pairs of means that are significantly different.

\begin{tabular}{|c|c|c|c|c|}
\hline $\begin{array}{l}\text { Level } \\
140 \mathrm{mg} / \mathrm{ml}\end{array}$ & A & & & $\begin{array}{r}\text { Mean } \\
1.4336667\end{array}$ \\
\hline $100 \mathrm{mg} / \mathrm{ml}$ & A & B & & 1.3433333 \\
\hline $60 \mathrm{mg} / \mathrm{ml}$ & A & B & C & 1.1926667 \\
\hline $80 \mathrm{mg} / \mathrm{ml}$ & A & B & C & 1.1880000 \\
\hline $120 \mathrm{mg} / \mathrm{ml}$ & & B & C & 1.1510000 \\
\hline TCP & & & C & 1.0486667 \\
\hline Media & & & & 0.0600000 \\
\hline
\end{tabular}

Levels not connected by same letter are significantly different.

$\begin{array}{ll}\text { Level } & \text { - Level } \\ 140 \mathrm{mg} / \mathrm{ml} & \text { Media } \\ 100 \mathrm{mg} / \mathrm{ml} & \text { Media } \\ 60 \mathrm{mg} / \mathrm{ml} & \text { Media } \\ 80 \mathrm{mg} / \mathrm{ml} & \text { Media } \\ 120 \mathrm{mg} / \mathrm{ml} & \text { Media }\end{array}$

$\begin{array}{rr}\text { Difference } & \text { Lower CL } \\ 1.373667 & 1.01491 \\ 1.283333 & 0.92457 \\ 1.132667 & 0.77391 \\ 1.128000 & 0.76924 \\ 1.091000 & 0.73224\end{array}$

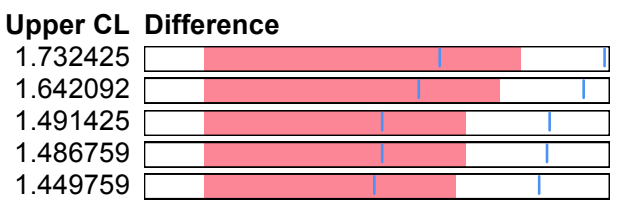




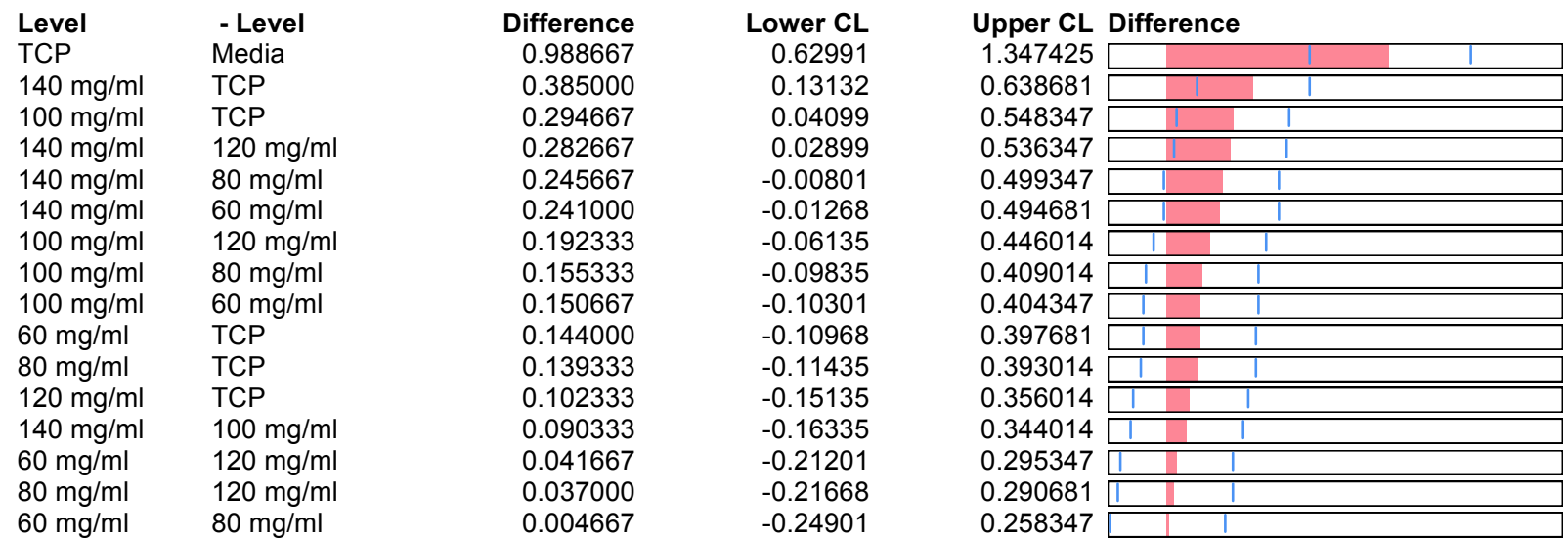

\section{Oneway Analysis of Day 14 by PDO scaffolds of varying concentration for VEGF secretion}

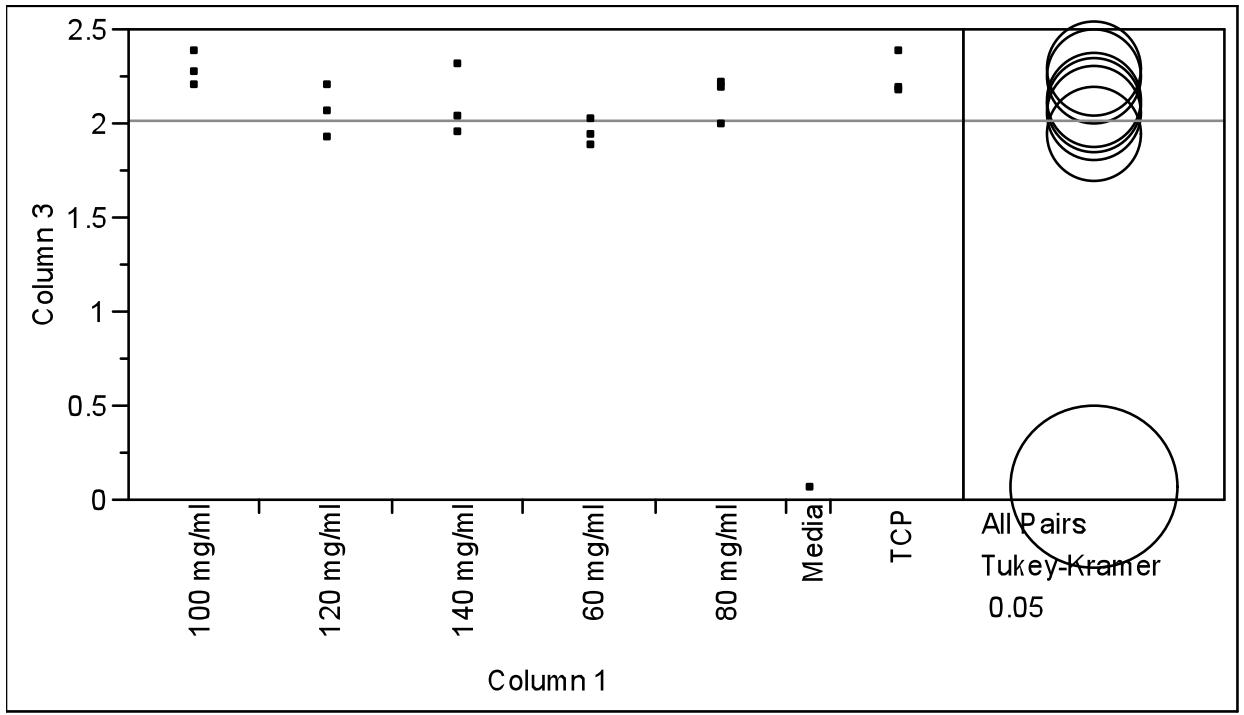

\section{Means Comparisons \\ Comparisons for all pairs using Tukey-Kramer HSD

$\begin{array}{rr}\mathbf{q}^{*} & \text { Alpha } \\ 3.49978 & 0.05\end{array}$

\begin{tabular}{|l|r|r|r|r|r|r|r|}
\hline Abs(Dif)-LSD & $\mathbf{1 0 0} \mathbf{~} \mathbf{g} / \mathbf{m l}$ & TCP & $\mathbf{8 0} \mathbf{~} \mathbf{~ g} / \mathbf{m l}$ & $\mathbf{1 4 0} \mathbf{~} \mathbf{g} / \mathbf{m l}$ & $\mathbf{1 2 0} \mathbf{~} \mathbf{g} / \mathbf{m l}$ & $\mathbf{6 0} \mathbf{~} \mathbf{g} / \mathbf{m l}$ & Media \\
\hline $100 \mathbf{~ m g} / \mathbf{m l}$ & -0.3592 & -0.3205 & -0.2038 & -0.1745 & -0.1332 & -0.0175 & 1.7144 \\
\hline $\mathrm{TCP}$ & -0.3205 & -0.3592 & -0.2425 & -0.2132 & -0.1718 & -0.0562 & 1.6757 \\
\hline $80 \mathbf{~ m g} / \mathrm{ml}$ & -0.2038 & -0.2425 & -0.3592 & -0.3298 & -0.2885 & -0.1728 & 1.5590 \\
\hline $140 \mathbf{~ m g} / \mathrm{ml}$ & -0.1745 & -0.2132 & -0.3298 & -0.3592 & -0.3178 & -0.2022 & 1.5297 \\
\hline $120 \mathbf{~ m g} / \mathrm{ml}$ & -0.1332 & -0.1718 & -0.2885 & -0.3178 & -0.3592 & -0.2435 & 1.4884 \\
\hline $60 \mathbf{~ m g} / \mathrm{ml}$ & -0.0175 & -0.0562 & -0.1728 & -0.2022 & -0.2435 & -0.3592 & 1.3727 \\
\hline Media & 1.7144 & 1.6757 & 1.5590 & 1.5297 & 1.4884 & 1.3727 & -0.6221 \\
\hline
\end{tabular}

Positive values show pairs of means that are significantly different.

Level

$100 \mathrm{mg} / \mathrm{ml}$ 


\begin{tabular}{|c|c|c|}
\hline Level & & Mean \\
\hline TCP & A & 2.2436667 \\
\hline 80 mg/ml & A & 2.1270000 \\
\hline $140 \mathrm{mg} / \mathrm{ml}$ & A & 2.0976667 \\
\hline $120 \mathrm{mg} / \mathrm{ml}$ & A & 2.0563333 \\
\hline $60 \mathrm{mg} / \mathrm{ml}$ & A & 1.9406667 \\
\hline Media & B & 0.0600000 \\
\hline
\end{tabular}

Levels not connected by same letter are significantly different.

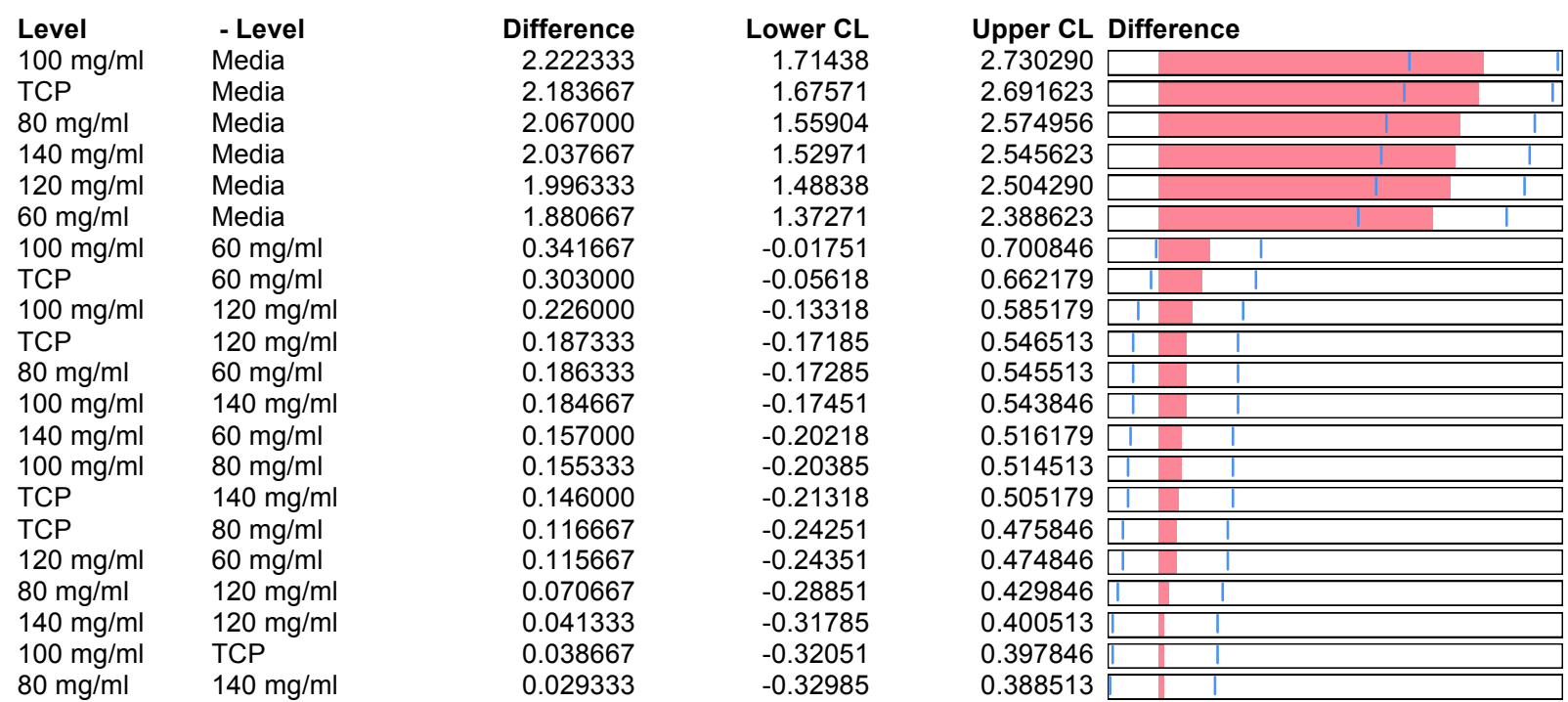

Oneway Analysis of Day 21 by PDO scaffolds of varying concentration for VEGF secretion

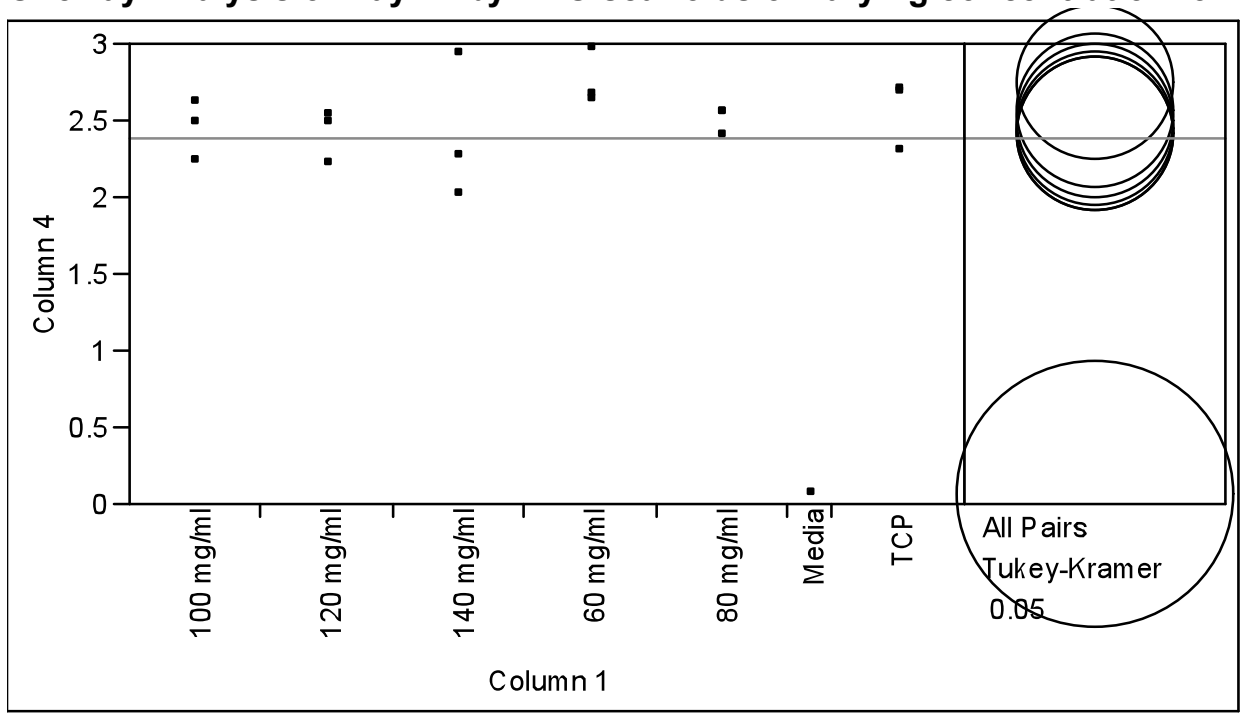

Means Comparisons

Comparisons for all pairs using Tukey-Kramer HSD

$\begin{array}{rr}\text { q*}^{*} & \text { Alpha } \\ 3.49978 & 0.05\end{array}$ 


\begin{tabular}{|l|r|r|r|r|r|r|r|}
\hline Abs(Dif)-LSD & $\mathbf{6 0} \mathbf{~} \mathbf{g} / \mathbf{m l}$ & TCP & $\mathbf{8 0} \mathbf{~} \mathbf{g} / \mathbf{m l}$ & $\mathbf{1 0 0} \mathbf{~} \mathbf{g} / \mathbf{m l}$ & $\mathbf{1 2 0} \mathbf{~} \mathbf{g} / \mathbf{m l}$ & $\mathbf{1 4 0} \mathbf{~} \mathbf{g} / \mathbf{m l}$ & Media \\
\hline $60 \mathbf{~ m g} / \mathbf{m l}$ & -0.7145 & -0.5218 & -0.4635 & -0.4088 & -0.3732 & -0.3678 & 1.6796 \\
\hline $\mathrm{TCP}$ & -0.5218 & -0.7145 & -0.6562 & -0.6015 & -0.5658 & -0.5605 & 1.4869 \\
\hline $80 \mathbf{~ m g} / \mathrm{ml}$ & -0.4635 & -0.6562 & -0.7145 & -0.6598 & -0.6242 & -0.6188 & 1.4286 \\
\hline $100 \mathbf{~ m g / m l}$ & -0.4088 & -0.6015 & -0.6598 & -0.7145 & -0.6788 & -0.6735 & 1.3739 \\
\hline $120 \mathbf{~ m g} / \mathrm{ml}$ & -0.3732 & -0.5658 & -0.6242 & -0.6788 & -0.7145 & -0.7092 & 1.3382 \\
\hline $140 \mathbf{~ m g} / \mathbf{m l}$ & -0.3678 & -0.5605 & -0.6188 & -0.6735 & -0.7092 & -0.7145 & 1.3329 \\
\hline Media & 1.6796 & 1.4869 & 1.4286 & 1.3739 & 1.3382 & 1.3329 & -1.2375 \\
\hline
\end{tabular}

Positive values show pairs of means that are significantly different.

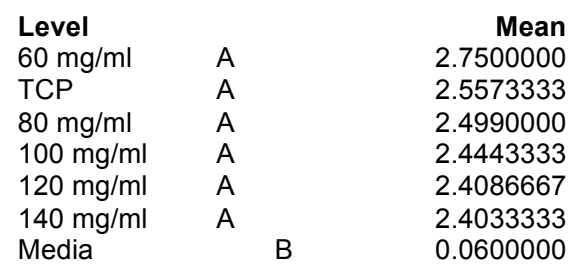

Levels not connected by same letter are significantly different.

$\begin{array}{llrr}\text { Level } & \text { - Level } & \text { Difference } & \text { Lower CL } \\ 60 \mathrm{mg} / \mathrm{ml} & \text { Media } & 2.690000 & 1.67955 \\ \mathrm{TCP} & \text { Media } & 2.497333 & 1.48688 \\ 80 \mathrm{mg} / \mathrm{ml} & \text { Media } & 2.439000 & 1.42855 \\ 100 \mathrm{mg} / \mathrm{ml} & \text { Media } & 2.384333 & 1.37388 \\ 120 \mathrm{mg} / \mathrm{ml} & \text { Media } & 2.348667 & 1.33822 \\ 140 \mathrm{mg} / \mathrm{ml} & \text { Media } & 2.343333 & 1.33288 \\ 60 \mathrm{mg} / \mathrm{ml} & 140 \mathrm{mg} / \mathrm{ml} & 0.346667 & -0.36783 \\ 60 \mathrm{mg} / \mathrm{ml} & 120 \mathrm{mg} / \mathrm{ml} & 0.341333 & -0.37316 \\ 60 \mathrm{mg} / \mathrm{ml} & 100 \mathrm{mg} / \mathrm{ml} & 0.305667 & -0.40883 \\ 60 \mathrm{mg} / \mathrm{ml} & 80 \mathrm{mg} / \mathrm{ml} & 0.251000 & -0.46350 \\ 60 \mathrm{mg} / \mathrm{ml} & \mathrm{TCP} & 0.192667 & -0.52183 \\ \mathrm{TCP} & 140 \mathrm{mg} / \mathrm{ml} & 0.154000 & -0.56050 \\ \mathrm{TCP} & 120 \mathrm{mg} / \mathrm{ml} & 0.148667 & -0.56583 \\ \mathrm{TCP} & 100 \mathrm{mg} / \mathrm{ml} & 0.113000 & -0.60150 \\ 80 \mathrm{mg} / \mathrm{ml} & 140 \mathrm{mg} / \mathrm{ml} & 0.095667 & -0.61883 \\ 80 \mathrm{mg} / \mathrm{ml} & 120 \mathrm{mg} / \mathrm{ml} & 0.090333 & -0.62416 \\ \mathrm{TCP} & 80 \mathrm{mg} / \mathrm{ml} & 0.058333 & -0.65616 \\ 80 \mathrm{mg} / \mathrm{ml} & 100 \mathrm{mg} / \mathrm{ml} & 0.054667 & -0.65983 \\ 100 \mathrm{mg} / \mathrm{ml} & 140 \mathrm{mg} / \mathrm{ml} & 0.041000 & -0.67350 \\ 100 \mathrm{mg} / \mathrm{ml} & 120 \mathrm{mg} / \mathrm{ml} & 0.035667 & -0.67883 \\ 120 \mathrm{mg} / \mathrm{ml} & 140 \mathrm{mg} / \mathrm{ml} & 0.005333 & -0.70916\end{array}$

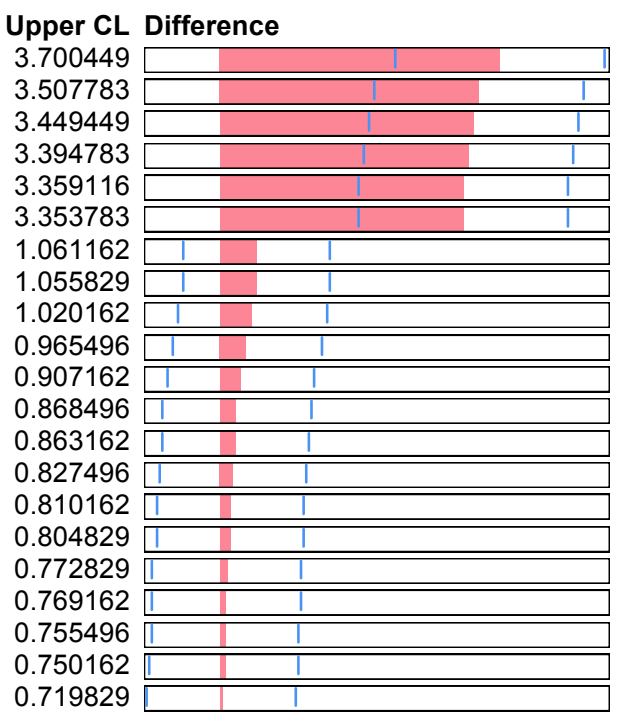


Oneway Analysis of Day 28 by PDO scaffolds of varying concentration for VEGF secretion

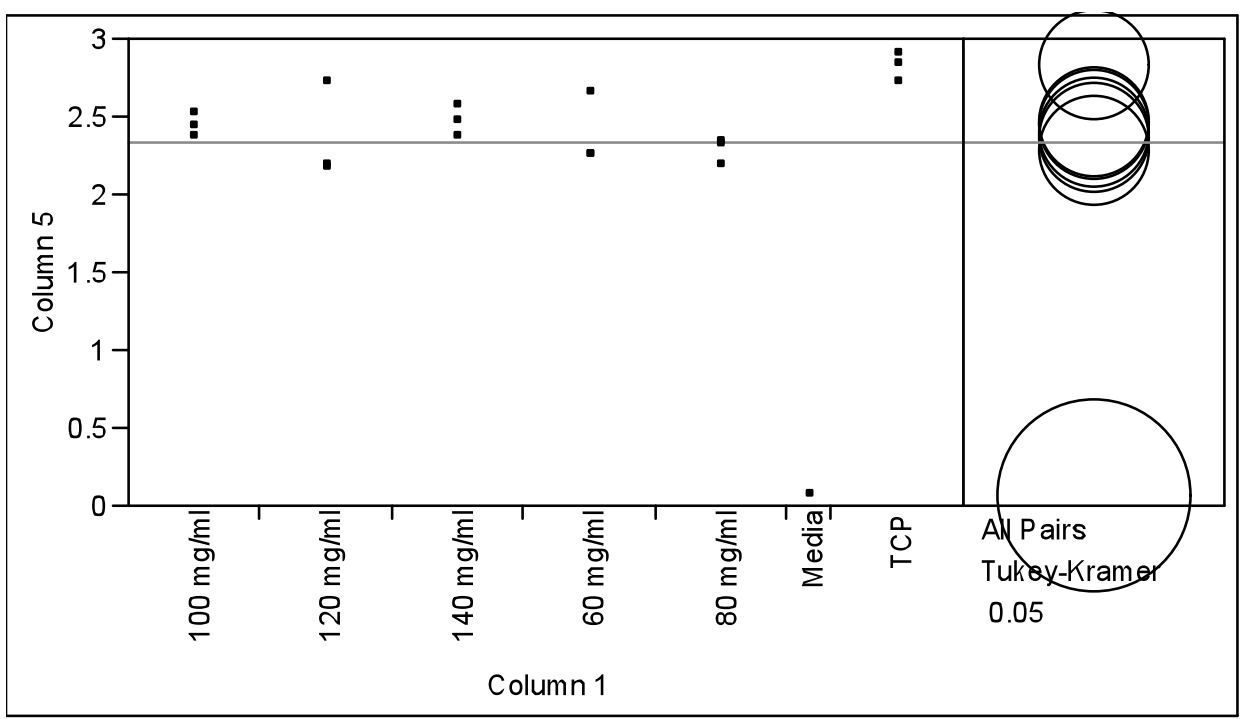

\section{Means Comparisons \\ Comparisons for all pairs using Tukey-Kramer HSD \\ $\mathbf{q}^{*}$ \\ Alpha \\ 3.49978}

\begin{tabular}{|l|r|r|r|r|r|r|r|}
\hline Abs(Dif)-LSD & TCP & $\mathbf{1 4 0} \mathbf{~} \mathbf{g} / \mathbf{m l}$ & $\mathbf{1 0 0} \mathbf{~} \mathbf{g} / \mathbf{m l}$ & $\mathbf{6 0} \mathbf{~} \mathbf{g} / \mathbf{m l}$ & $\mathbf{1 2 0} \mathbf{~ m g} / \mathbf{m l}$ & $\mathbf{8 0} \mathbf{~ m g} / \mathbf{m l}$ & $\mathbf{M e d i a}$ \\
\hline $\mathrm{TCP}$ & -0.5027 & -0.1447 & -0.1207 & -0.0687 & -0.0370 & 0.0443 & 2.0511 \\
\hline $140 \mathrm{mg} / \mathrm{ml}$ & -0.1447 & -0.5027 & -0.4787 & -0.4267 & -0.3950 & -0.3137 & 1.6931 \\
\hline $100 \mathrm{mg} / \mathrm{ml}$ & -0.1207 & -0.4787 & -0.5027 & -0.4507 & -0.4190 & -0.3377 & 1.6691 \\
\hline $60 \mathrm{mg} / \mathrm{ml}$ & -0.0687 & -0.4267 & -0.4507 & -0.5027 & -0.4710 & -0.3897 & 1.6171 \\
\hline $120 \mathrm{mg} / \mathrm{ml}$ & -0.0370 & -0.3950 & -0.4190 & -0.4710 & -0.5027 & -0.4213 & 1.5854 \\
\hline $80 \mathrm{mg} / \mathrm{ml}$ & 0.0443 & -0.3137 & -0.3377 & -0.3897 & -0.4213 & -0.5027 & 1.5041 \\
\hline Media & 2.0511 & 1.6931 & 1.6691 & 1.6171 & 1.5854 & 1.5041 & -0.8707 \\
\hline
\end{tabular}

Positive values show pairs of means that are significantly different.

$\begin{array}{lcccr}\text { Level } & & & & \text { Mean } \\ \text { TCP } & \text { A } & & & 2.8220000 \\ 140 \mathrm{mg} / \mathrm{ml} & \text { A } & \text { B } & & 2.4640000 \\ 100 \mathrm{mg} / \mathrm{ml} & \text { A } & \text { B } & & 2.4400000 \\ 60 \mathrm{mg} / \mathrm{ml} & \text { A } & \text { B } & 2.3880000 \\ 120 \mathrm{mg} / \mathrm{ml} & \text { A } & \text { B } & 2.3563333 \\ 80 \mathrm{mg} / \mathrm{ml} & & \text { B } & 2.2750000 \\ \text { Media } & & & \text { C } & 0.0600000\end{array}$

Levels not connected by same letter are significantly different.

$\begin{array}{llrr}\text { Level } & \text { - Level } & \text { Difference } & \text { Lower } \mathbf{C L} \\ \text { TCP } & \text { Media } & 2.762000 & 2.05110 \\ 140 \mathrm{mg} / \mathrm{ml} & \text { Media } & 2.404000 & 1.69310 \\ 100 \mathrm{mg} / \mathrm{ml} & \text { Media } & 2.380000 & 1.66910 \\ 60 \mathrm{mg} / \mathrm{ml} & \text { Media } & 2.328000 & 1.61710 \\ 120 \mathrm{mg} / \mathrm{ml} & \text { Media } & 2.296333 & 1.58544 \\ 80 \mathrm{mg} / \mathrm{ml} & \text { Media } & 2.215000 & 1.50410 \\ \mathrm{TCP} & 80 \mathrm{mg} / \mathrm{ml} & 0.547000 & 0.04432 \\ \mathrm{TCP} & 120 \mathrm{mg} / \mathrm{ml} & 0.465667 & -0.03701\end{array}$

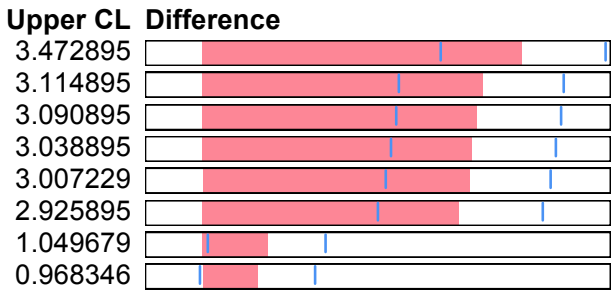




\begin{tabular}{|c|c|c|c|c|c|}
\hline Level & - Level & Difference & Lower CL & Upper CL & Difference \\
\hline TCP & $60 \mathrm{mg} / \mathrm{ml}$ & 0.434000 & -0.06868 & 0.936679 & 1 \\
\hline TCP & $100 \mathrm{mg} / \mathrm{ml}$ & 0.382000 & -0.12068 & 0.884679 & \\
\hline TCP & $140 \mathrm{mg} / \mathrm{ml}$ & 0.358000 & -0.14468 & 0.860679 & \\
\hline $140 \mathrm{mg} / \mathrm{ml}$ & $80 \mathrm{mg} / \mathrm{ml}$ & 0.189000 & -0.31368 & 0.691679 & 1 \\
\hline $100 \mathrm{mg} / \mathrm{ml}$ & $80 \mathrm{mg} / \mathrm{ml}$ & 0.165000 & -0.33768 & 0.667679 & $T$ \\
\hline $60 \mathrm{mg} / \mathrm{ml}$ & 80 mg/ml & 0.113000 & -0.38968 & 0.615679 & $T$ \\
\hline $140 \mathrm{mg} / \mathrm{ml}$ & $120 \mathrm{mg} / \mathrm{ml}$ & 0.107667 & -0.39501 & 0.610346 & $\overline{11}$ \\
\hline $100 \mathrm{mg} / \mathrm{ml}$ & $120 \mathrm{mg} / \mathrm{ml}$ & 0.083667 & -0.41901 & 0.586346 & 1 \\
\hline $120 \mathrm{mg} / \mathrm{ml}$ & $80 \mathrm{mg} / \mathrm{ml}$ & 0.081333 & -0.42135 & 0.584012 & 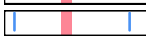 \\
\hline $140 \mathrm{mg} / \mathrm{ml}$ & $60 \mathrm{mg} / \mathrm{ml}$ & 0.076000 & -0.42668 & 0.578679 & 1 \\
\hline $100 \mathrm{mg} / \mathrm{ml}$ & $60 \mathrm{mg} / \mathrm{ml}$ & 0.052000 & -0.45068 & 0.554679 & 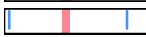 \\
\hline $60 \mathrm{mg} / \mathrm{ml}$ & $120 \mathrm{mg} / \mathrm{ml}$ & 0.031667 & -0.47101 & 0.534346 & 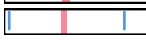 \\
\hline $140 \mathrm{mg} / \mathrm{ml}$ & $100 \mathrm{mg} / \mathrm{ml}$ & 0.024000 & -0.47868 & 0.526679 & \\
\hline
\end{tabular}

Fit $Y$ by $X$ Group

Oneway Analysis of Day 7 by PDO scaffolds of varying concentration for aFGF secretion

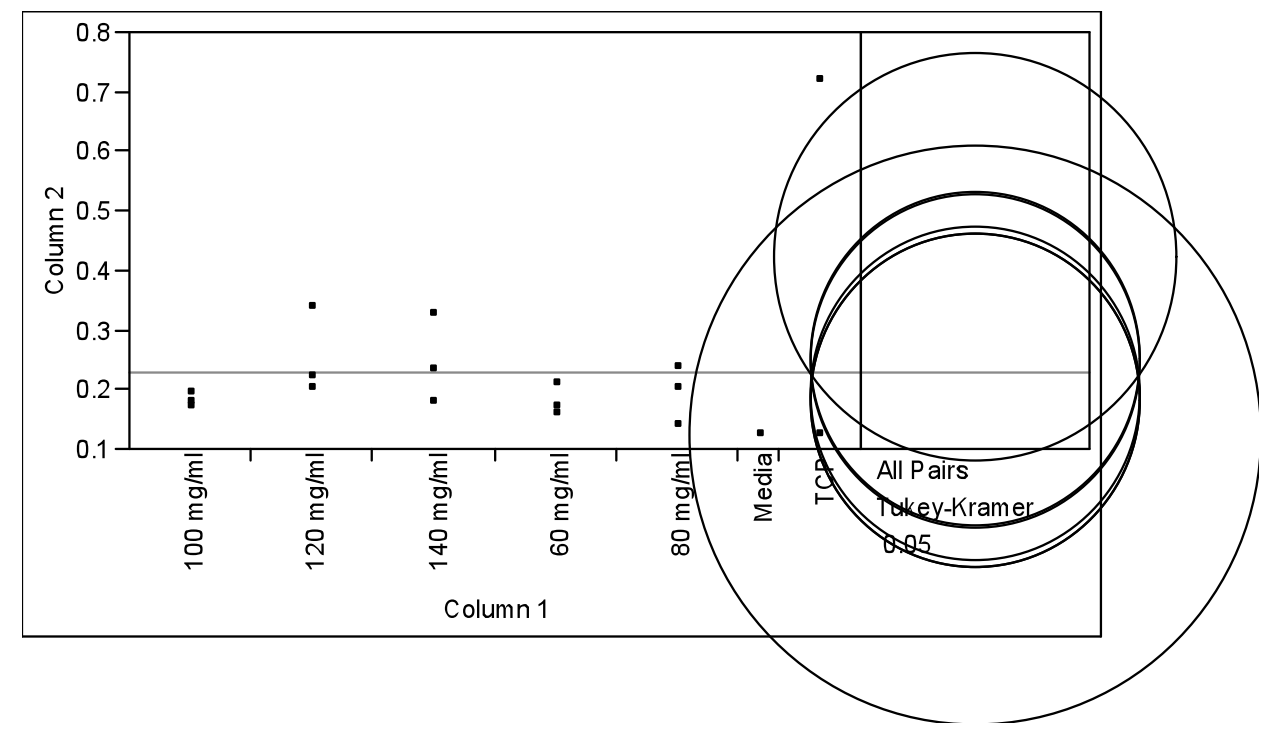

Missing Rows

1

Means Comparisons

Comparisons for all pairs using Tukey-Kramer HSD

$\begin{array}{rr}\mathbf{q}^{*} & \text { Alpha } \\ 3.55539 & 0.05\end{array}$

\begin{tabular}{|c|c|c|c|c|c|c|c|}
\hline Abs(Dif)-LSD & TCP & $120 \mathrm{mg} / \mathrm{ml}$ & $140 \mathrm{mg} / \mathrm{ml}$ & $80 \mathrm{mg} / \mathrm{ml}$ & $60 \mathrm{mg} / \mathrm{ml}$ & $100 \mathrm{mg} / \mathrm{ml}$ & Media \\
\hline TCP & -0.48520 & -0.27559 & -0.26892 & -0.21492 & -0.20292 & -0.20259 & -0.29824 \\
\hline $120 \mathrm{mg} / \mathrm{ml}$ & -0.27559 & -0.39616 & -0.38950 & -0.33550 & -0.32350 & -0.32316 & -0.43159 \\
\hline $140 \mathrm{mg} / \mathrm{ml}$ & -0.26892 & -0.38950 & -0.39616 & -0.34216 & -0.33016 & -0.32983 & -0.43826 \\
\hline $80 \mathrm{mg} / \mathrm{ml}$ & -0.21492 & -0.33550 & -0.34216 & -0.39616 & -0.38416 & -0.38383 & -0.49226 \\
\hline $60 \mathrm{mg} / \mathrm{ml}$ & -0.20292 & -0.32350 & -0.33016 & -0.38416 & -0.39616 & -0.39583 & -0.50426 \\
\hline $100 \mathrm{mg} / \mathrm{ml}$ & -0.20259 & -0.32316 & -0.32983 & -0.38383 & -0.39583 & -0.39616 & -0.50459 \\
\hline Media & -0.29824 & -0.43159 & -0.43826 & -0.49226 & -0.50426 & -0.50459 & -0.68617 \\
\hline
\end{tabular}

Positive values show pairs of means that are significantly different. 


$\begin{array}{llr}\text { Level } & & \text { Mean } \\ \text { TCP } & \text { A } & 0.42000000 \\ 120 \mathrm{mg} / \mathrm{ml} & \text { A } & 0.25266667 \\ 140 \mathrm{mg} / \mathrm{ml} & \text { A } & 0.24600000 \\ 80 \mathrm{mg} / \mathrm{ml} & \text { A } & 0.19200000 \\ 60 \mathrm{mg} / \mathrm{ml} & \text { A } & 0.18000000 \\ 100 \mathrm{mg} / \mathrm{ml} & \text { A } & 0.17966667 \\ \text { Media } & \text { A } & 0.12400000\end{array}$

Levels not connected by same letter are significantly different.

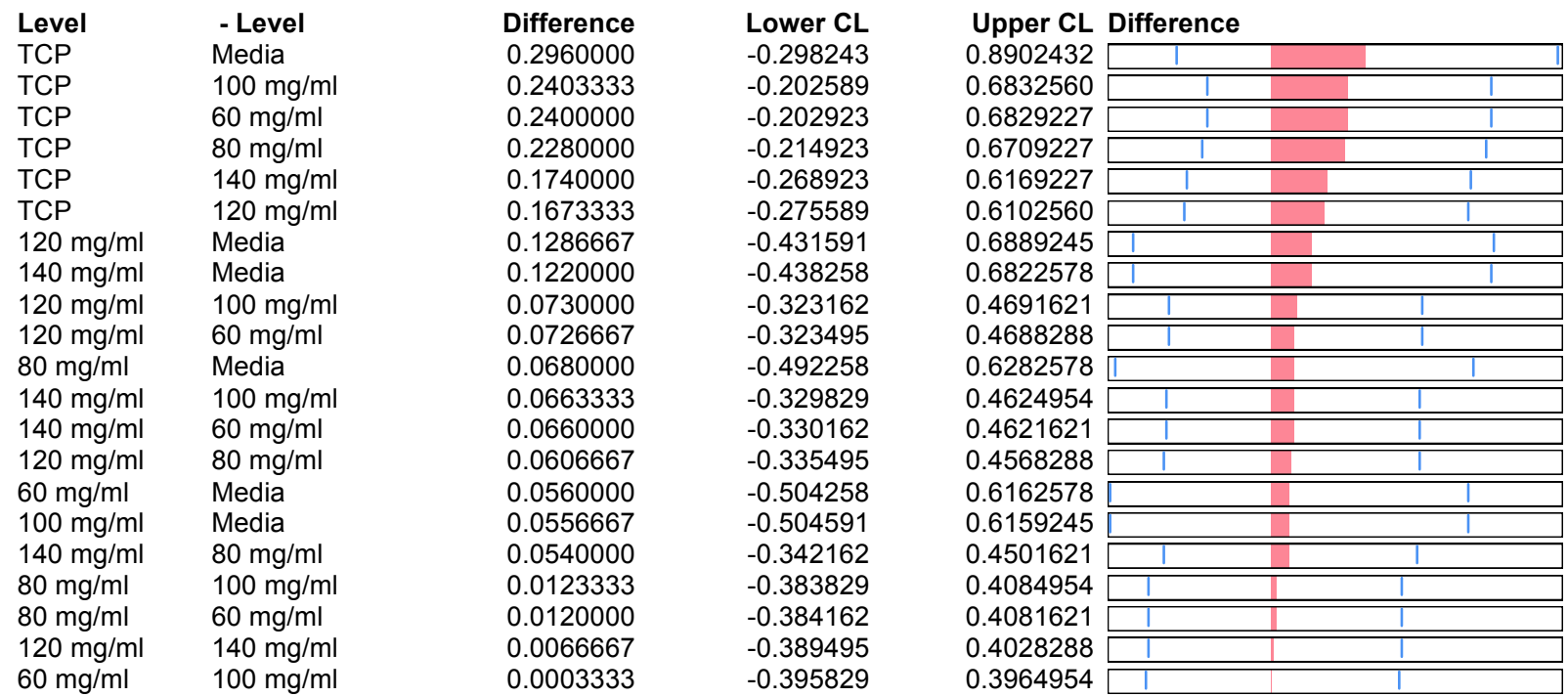

\section{Oneway Analysis of Day 14 by PDO scaffolds of varying concentration for aFGF secretion}

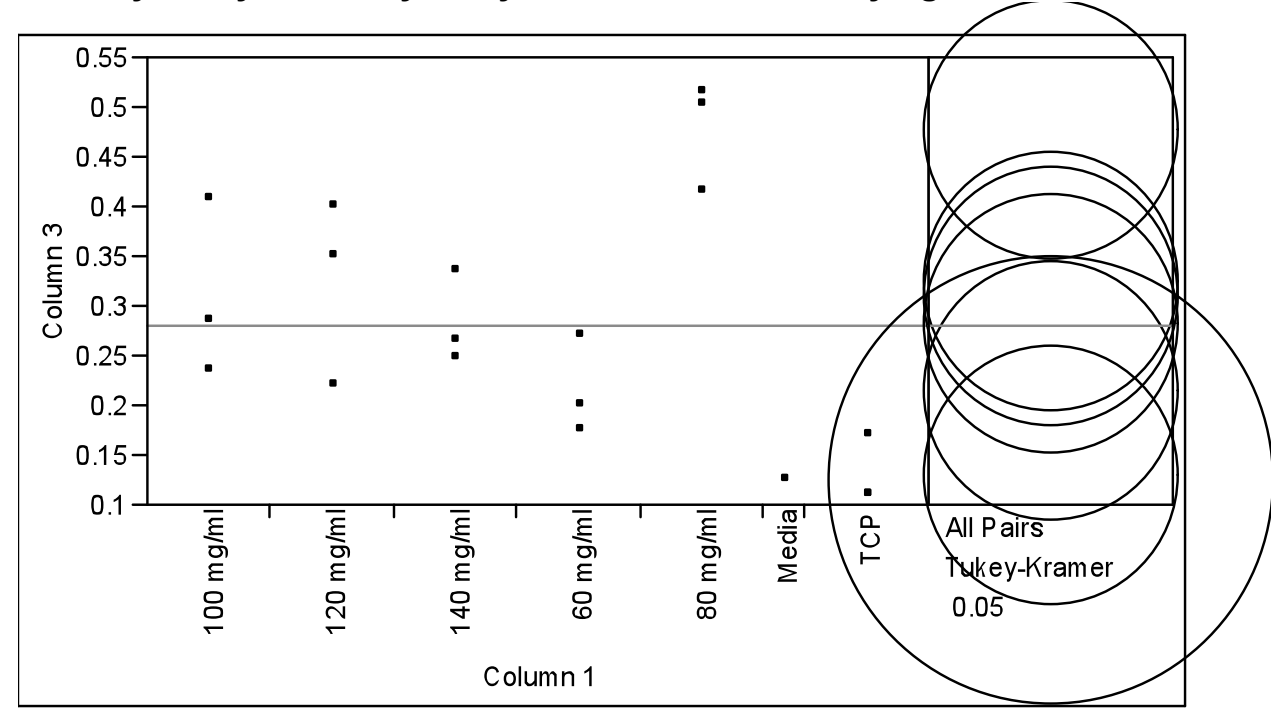

\section{Means Comparisons \\ Comparisons for all pairs using Tukey-Kramer HSD \\ $q^{*} \quad$ Alpha \\ $3.49978 \quad 0.05$}


$q^{*}$

Alpha

\begin{tabular}{|l|r|r|r|r|r|r|r|}
\hline Abs(Dif)-LSD & $\mathbf{8 0} \mathbf{~} \mathbf{~ g / m l}$ & $\mathbf{1 2 0} \mathbf{~} \mathbf{g} / \mathbf{m l}$ & $\mathbf{1 0 0} \mathbf{~} \mathbf{g} / \mathbf{m l}$ & $\mathbf{1 4 0} \mathbf{~} \mathbf{g} / \mathbf{m l}$ & $\mathbf{6 0} \mathbf{~} \mathbf{g} / \mathbf{m l}$ & TCP & Media \\
\hline $80 \mathbf{~ m g} / \mathbf{m l}$ & -0.18488 & -0.03221 & -0.01654 & 0.00979 & 0.07679 & 0.16212 & 0.09155 \\
\hline $120 \mathbf{~ g} / \mathbf{m l}$ & -0.03221 & -0.18488 & -0.16921 & -0.14288 & -0.07588 & 0.00946 & -0.06112 \\
\hline $100 \mathbf{~ m g} / \mathbf{m l}$ & -0.01654 & -0.16921 & -0.18488 & -0.15854 & -0.09154 & -0.00621 & -0.07679 \\
\hline $140 \mathbf{~ m g} / \mathbf{m l}$ & 0.00979 & -0.14288 & -0.15854 & -0.18488 & -0.11788 & -0.03254 & -0.10312 \\
\hline $60 \mathbf{~ m g} / \mathbf{m l}$ & 0.07679 & -0.07588 & -0.09154 & -0.11788 & -0.18488 & -0.09954 & -0.17012 \\
\hline $\mathrm{TCP}$ & 0.16212 & 0.00946 & -0.00621 & -0.03254 & -0.09954 & -0.18488 & -0.25545 \\
\hline Media & 0.09155 & -0.06112 & -0.07679 & -0.10312 & -0.17012 & -0.25545 & -0.32021 \\
\hline
\end{tabular}

Positive values show pairs of means that are significantly different.

$\begin{array}{llllr}\text { Level } & & & & \text { Mean } \\ 80 \mathrm{mg} / \mathrm{ml} & \text { A } & & & 0.47700000 \\ 120 \mathrm{mg} / \mathrm{ml} & \text { A } & \text { B } & & 0.32433333 \\ 100 \mathrm{mg} / \mathrm{ml} & \text { A } & \text { B } & \text { C } & 0.30866667 \\ 140 \mathrm{mg} / \mathrm{ml} & & \text { B } & \text { C } & 0.28233333 \\ 60 \mathrm{mg} / \mathrm{ml} & & \text { B } & \text { C } & 0.21533333 \\ \text { TCP } & & & \text { C } & 0.13000000 \\ \text { Media } & & \text { B } & \text { C } & 0.12400000\end{array}$

Levels not connected by same letter are significantly different.

$\begin{array}{llrr}\text { Level } & \text { - Level } & \text { Difference } & \text { Lower CL } \\ 80 \mathrm{mg} / \mathrm{ml} & \text { Media } & 0.3530000 & 0.091546 \\ 80 \mathrm{mg} / \mathrm{ml} & \text { TCP } & 0.3470000 & 0.162124 \\ 80 \mathrm{mg} / \mathrm{ml} & 60 \mathrm{mg} / \mathrm{ml} & 0.2616667 & 0.076791 \\ 120 \mathrm{mg} / \mathrm{ml} & \text { Media } & 0.2003333 & -0.061121 \\ 80 \mathrm{mg} / \mathrm{ml} & 140 \mathrm{mg} / \mathrm{ml} & 0.1946667 & 0.009791 \\ 120 \mathrm{mg} / \mathrm{ml} & \text { TCP } & 0.1943333 & 0.009457 \\ 100 \mathrm{mg} / \mathrm{ml} & \text { Media } & 0.1846667 & -0.076787 \\ 100 \mathrm{mg} / \mathrm{ml} & \text { TCP } & 0.1786667 & -0.006209 \\ 80 \mathrm{mg} / \mathrm{ml} & 100 \mathrm{mg} / \mathrm{ml} & 0.1683333 & -0.016543 \\ 140 \mathrm{mg} / \mathrm{ml} & \text { Media } & 0.1583333 & -0.103121 \\ 80 \mathrm{mg} / \mathrm{ml} & 120 \mathrm{mg} / \mathrm{ml} & 0.1526667 & -0.032209 \\ 140 \mathrm{mg} / \mathrm{ml} & \text { TCP } & 0.1523333 & -0.032543 \\ 120 \mathrm{mg} / \mathrm{ml} & 60 \mathrm{mg} / \mathrm{ml} & 0.1090000 & -0.075876 \\ 100 \mathrm{mg} / \mathrm{ml} & 60 \mathrm{mg} / \mathrm{ml} & 0.0933333 & -0.091543 \\ 60 \mathrm{mg} / \mathrm{ml} & \text { Media } & 0.0913333 & -0.170121 \\ 60 \mathrm{mg} / \mathrm{ml} & \text { TCP } & 0.0853333 & -0.099543 \\ 140 \mathrm{mg} / \mathrm{ml} & 60 \mathrm{mg} / \mathrm{ml} & 0.0670000 & -0.117876 \\ 120 \mathrm{mg} / \mathrm{ml} & 140 \mathrm{mg} / \mathrm{ml} & 0.0420000 & -0.142876 \\ 100 \mathrm{mg} / \mathrm{ml} & 140 \mathrm{mg} / \mathrm{ml} & 0.0263333 & -0.158543 \\ 120 \mathrm{mg} / \mathrm{ml} & 100 \mathrm{mg} / \mathrm{ml} & 0.0156667 & -0.169209 \\ \mathrm{TCP} & \text { Media } & 0.0060000 & -0.255454\end{array}$

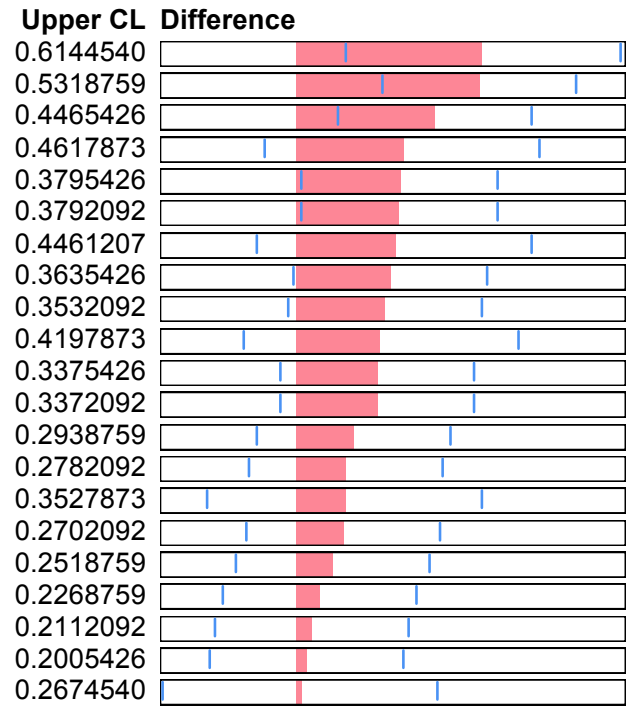


Oneway Analysis of Day 21 by PDO scaffolds of varying concentration for aFGF secretion

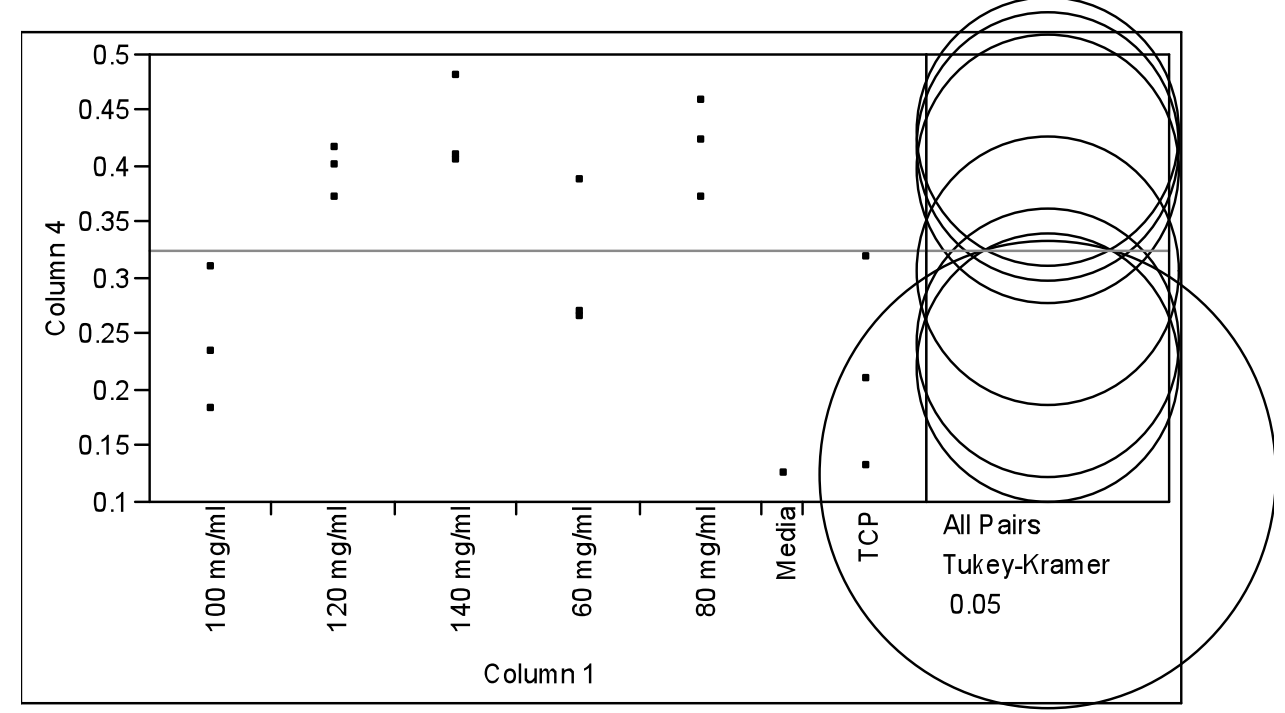

\section{Means Comparisons \\ Comparisons for all pairs using Tukey-Kramer HSD \\ $q^{*}$ \\ Alpha \\ 3.49978 \\ 0.05}

\begin{tabular}{|c|c|c|c|c|c|c|c|}
\hline Abs(Dif)-LSD & $140 \mathrm{mg} / \mathrm{ml}$ & $80 \mathrm{mg} / \mathrm{ml}$ & $120 \mathrm{mg} / \mathrm{ml}$ & $60 \mathrm{mg} / \mathrm{ml}$ & $100 \mathrm{mg} / \mathrm{ml}$ & TCP & Media \\
\hline $140 \mathrm{mg} / \mathrm{ml}$ & -0.17096 & -0.15763 & -0.13596 & -0.04663 & 0.01804 & 0.04104 & 0.06522 \\
\hline $80 \mathrm{mg} / \mathrm{ml}$ & -0.15763 & -0.17096 & -0.14930 & -0.05996 & 0.00470 & 0.02770 & 0.05189 \\
\hline $120 \mathrm{mg} / \mathrm{ml}$ & -0.13596 & -0.14930 & -0.17096 & -0.08163 & -0.01696 & 0.00604 & 0.03022 \\
\hline $60 \mathrm{mg} / \mathrm{ml}$ & -0.04663 & -0.05996 & -0.08163 & -0.17096 & -0.10630 & -0.08330 & -0.05911 \\
\hline $100 \mathrm{mg} / \mathrm{ml}$ & 0.01804 & 0.00470 & -0.01696 & -0.10630 & -0.17096 & -0.14796 & -0.12378 \\
\hline TCP & 0.04104 & 0.02770 & 0.00604 & -0.08330 & -0.14796 & -0.17096 & -0.14678 \\
\hline Media & 0.06522 & 0.05189 & 0.03022 & -0.05911 & -0.12378 & -0.14678 & -0.29612 \\
\hline
\end{tabular}

Positive values show pairs of means that are significantly different.

$\begin{array}{llllr}\text { Level } & & & & \text { Mean } \\ 140 \mathrm{mg} / \mathrm{ml} & \text { A } & & & 0.43100000 \\ 80 \mathrm{mg} / \mathrm{ml} & \text { A } & & & 0.41766667 \\ 120 \mathrm{mg} / \mathrm{ml} & \text { A } & \text { B } & & 0.39600000 \\ 60 \mathrm{mg} / \mathrm{ml} & \text { A } & \text { B } & \text { C } & 0.30666667 \\ 100 \mathrm{mg} / \mathrm{ml} & & \text { B } & \text { C } & 0.24200000 \\ \text { TCP } & & & \text { C } & 0.21900000 \\ \text { Media } & & & \text { C } & 0.12400000\end{array}$

Levels not connected by same letter are significantly different.

$\begin{array}{llrr}\text { Level } & \text { - Level } & \text { Difference } & \text { Lower CL } \\ 140 \mathrm{mg} / \mathrm{ml} & \text { Media } & 0.3070000 & 0.065221 \\ 80 \mathrm{mg} / \mathrm{ml} & \text { Media } & 0.2936667 & 0.051888 \\ 120 \mathrm{mg} / \mathrm{ml} & \text { Media } & 0.2720000 & 0.030221 \\ 140 \mathrm{mg} / \mathrm{ml} & \text { TCP } & 0.2120000 & 0.041037 \\ 80 \mathrm{mg} / \mathrm{ml} & \text { TCP } & 0.1986667 & 0.027703 \\ 140 \mathrm{mg} / \mathrm{ml} & 100 \mathrm{mg} / \mathrm{ml} & 0.1890000 & 0.018037 \\ 60 \mathrm{mg} / \mathrm{ml} & \text { Media } & 0.1826667 & -0.059112 \\ 120 \mathrm{mg} / \mathrm{ml} & \text { TCP } & 0.1770000 & 0.006037 \\ 80 \mathrm{mg} / \mathrm{ml} & 100 \mathrm{mg} / \mathrm{ml} & 0.1756667 & 0.004703\end{array}$

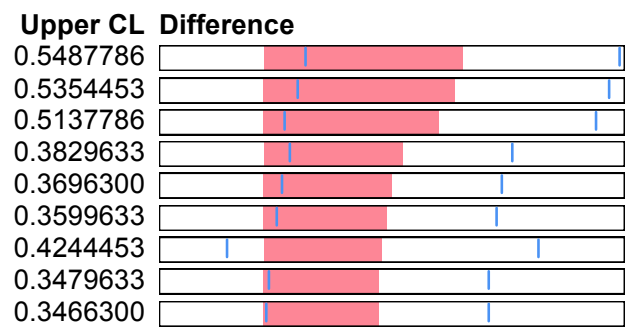




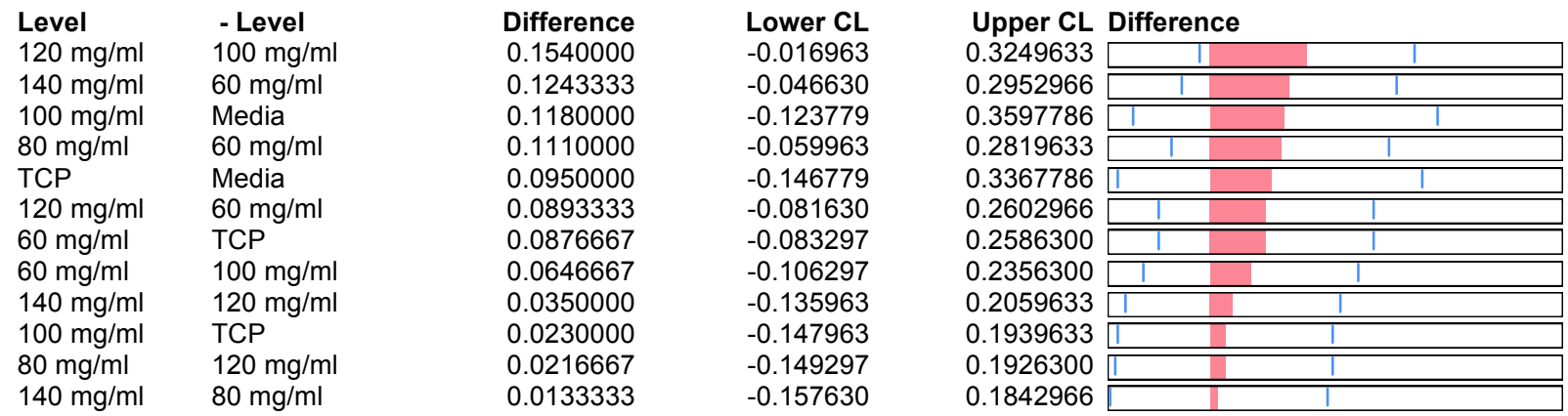

\section{Oneway Analysis of Day 28 by PDO scaffolds of varying concentration for aFGF secretion}

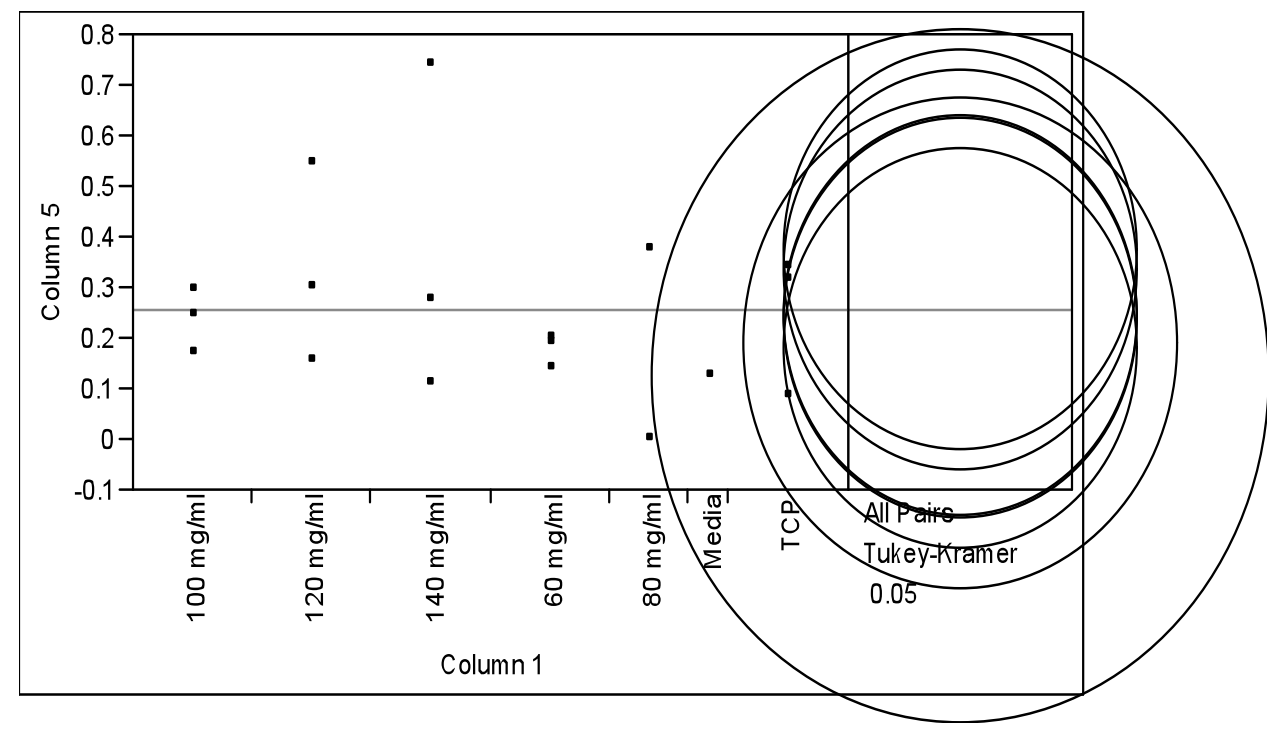

Missing Rows

\section{1}

Means Comparisons

Comparisons for all pairs using Tukey-Kramer HSD

$\mathbf{q}^{*}$

Alpha

$3.55539 \quad 0.05$

\begin{tabular}{|c|c|c|c|c|c|c|c|}
\hline Abs(Dif)-LSD & $140 \mathrm{mg} / \mathrm{ml}$ & $120 \mathrm{mg} / \mathrm{ml}$ & TCP & $100 \mathrm{mg} / \mathrm{ml}$ & $80 \mathrm{mg} / \mathrm{ml}$ & $60 \mathrm{mg} / \mathrm{ml}$ & Media \\
\hline $140 \mathrm{mg} / \mathrm{ml}$ & -0.56167 & -0.52034 & -0.43200 & -0.42300 & -0.44146 & -0.36300 & -0.54332 \\
\hline $120 \mathrm{mg} / \mathrm{ml}$ & -0.52034 & -0.56167 & -0.47334 & -0.46434 & -0.48280 & -0.40434 & -0.58465 \\
\hline TCP & -0.43200 & -0.47334 & -0.56167 & -0.55267 & -0.57113 & -0.49267 & -0.67299 \\
\hline $100 \mathrm{mg} / \mathrm{ml}$ & -0.42300 & -0.46434 & -0.55267 & -0.56167 & -0.58013 & -0.50167 & -0.68199 \\
\hline $80 \mathrm{mg} / \mathrm{ml}$ & -0.44146 & -0.48280 & -0.57113 & -0.58013 & -0.68790 & -0.61580 & -0.77800 \\
\hline $60 \mathrm{mg} / \mathrm{ml}$ & -0.36300 & -0.40434 & -0.49267 & -0.50167 & -0.61580 & -0.56167 & -0.74199 \\
\hline Media & -0.54332 & -0.58465 & -0.67299 & -0.68199 & -0.77800 & -0.74199 & -0.97284 \\
\hline
\end{tabular}

Positive values show pairs of means that are significantly different.

$\begin{array}{llr}\text { Level } & & \text { Mean } \\ 140 \mathrm{mg} / \mathrm{ml} & \text { A } & 0.37500000 \\ 120 \mathrm{mg} / \mathrm{ml} & \text { A } & 0.33366667 \\ \mathrm{TCP} & \text { A } & 0.24533333 \\ 100 \mathrm{mg} / \mathrm{ml} & \text { A } & 0.23633333\end{array}$




\section{Level}

$80 \mathrm{mg} / \mathrm{ml}$

$60 \mathrm{mg} / \mathrm{ml}$

Media

$\begin{array}{rr} & \text { Mean } \\ \text { A } & 0.18850000 \\ \text { A } & 0.17633333 \\ \text { A } & 0.12400000\end{array}$

Levels not connected by same letter are significantly different

$\begin{array}{llll}\text { Level } & \text { - Level } & \text { Difference } & \text { Lower CL } \\ 140 \mathrm{mg} / \mathrm{ml} & \text { Media } & 0.2510000 & -0.543320 \\ 120 \mathrm{mg} / \mathrm{ml} & \text { Media } & 0.2096667 & -0.584653 \\ 140 \mathrm{mg} / \mathrm{ml} & 60 \mathrm{mg} / \mathrm{ml} & 0.1986667 & -0.363002 \\ 140 \mathrm{mg} / \mathrm{ml} & 80 \mathrm{mg} / \mathrm{ml} & 0.1865000 & -0.441465 \\ 120 \mathrm{mg} / \mathrm{ml} & 60 \mathrm{mg} / \mathrm{ml} & 0.1573333 & -0.404336 \\ 120 \mathrm{mg} / \mathrm{ml} & 80 \mathrm{mg} / \mathrm{ml} & 0.1451667 & -0.482798 \\ 140 \mathrm{mg} / \mathrm{ml} & 100 \mathrm{mg} / \mathrm{ml} & 0.1386667 & -0.423002 \\ 140 \mathrm{mg} / \mathrm{ml} & \mathrm{TCP} & 0.1296667 & -0.432002 \\ \mathrm{TCP} & \text { Media } & 0.1213333 & -0.672987 \\ 100 \mathrm{mg} / \mathrm{ml} & \text { Media } & 0.1123333 & -0.681987 \\ 120 \mathrm{mg} / \mathrm{ml} & 100 \mathrm{mg} / \mathrm{ml} & 0.0973333 & -0.464336 \\ 120 \mathrm{mg} / \mathrm{ml} & \mathrm{TCP} & 0.0883333 & -0.473336 \\ \mathrm{TCP} & 60 \mathrm{mg} / \mathrm{ml} & 0.0690000 & -0.492669 \\ 80 \mathrm{mg} / \mathrm{ml} & \mathrm{Media} & 0.0645000 & -0.778003 \\ 100 \mathrm{mg} / \mathrm{ml} & 60 \mathrm{mg} / \mathrm{ml} & 0.0600000 & -0.501669 \\ \mathrm{TCP} & 80 \mathrm{mg} / \mathrm{ml} & 0.0568333 & -0.571132 \\ 60 \mathrm{mg} / \mathrm{ml} & \mathrm{Media} & 0.0523333 & -0.741987 \\ 100 \mathrm{mg} / \mathrm{ml} & 80 \mathrm{mg} / \mathrm{ml} & 0.0478333 & -0.580132 \\ 140 \mathrm{mg} / \mathrm{ml} & 120 \mathrm{mg} / \mathrm{ml} & 0.0413333 & -0.520336 \\ 80 \mathrm{mg} / \mathrm{ml} & 60 \mathrm{mg} / \mathrm{ml} & 0.0121667 & -0.615798 \\ \mathrm{TCP} & 100 \mathrm{mg} / \mathrm{ml} & 0.0090000 & -0.552669\end{array}$

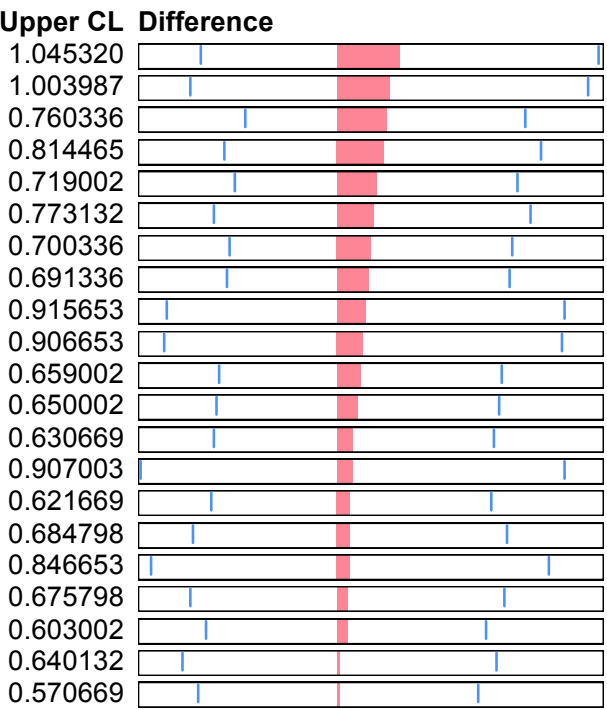

Fit $Y$ by $X$ Group

Oneway Analysis of Day 7 By PDO scaffolds of varying concentration for TGF- $\beta 1$ secretion

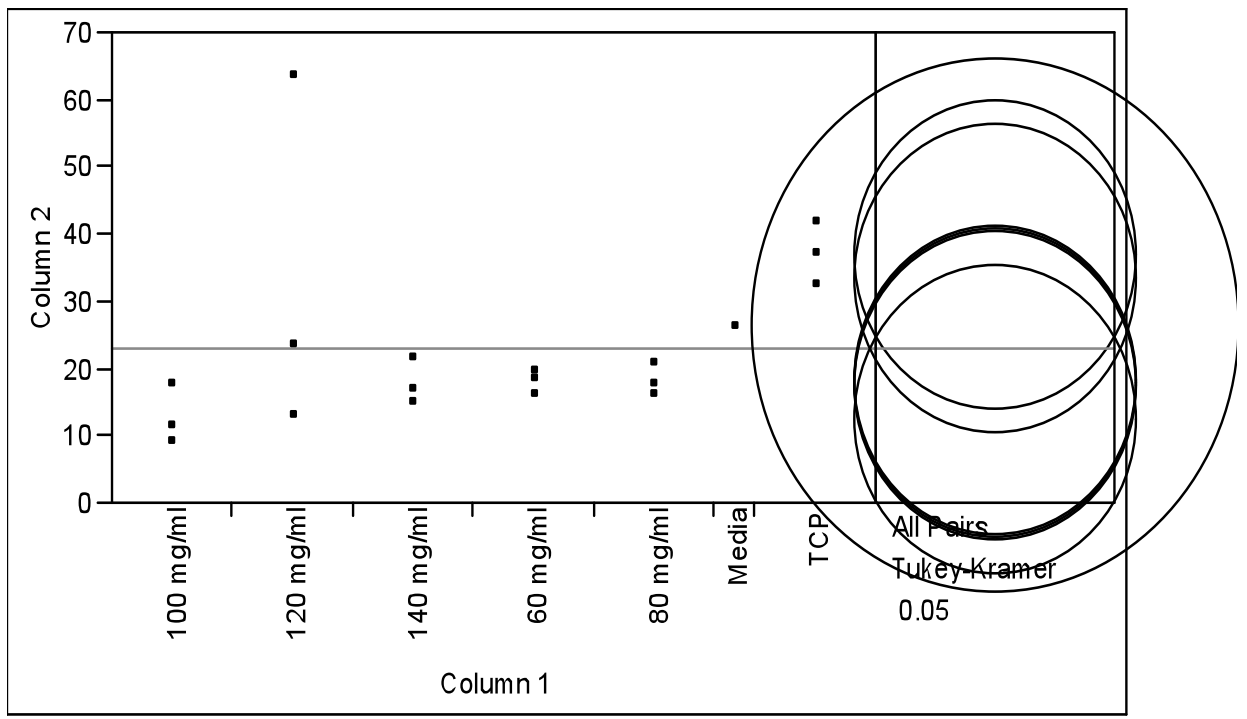

\section{Means Comparisons \\ Comparisons for all pairs using Tukey-Kramer HSD \\ $q^{*}$ \\ Alpha}


$\begin{array}{rr}\mathbf{q}^{*} & \text { Alpha } \\ 3.49978 & 0.05\end{array}$

\begin{tabular}{|l|r|r|r|r|r|r|r|}
\hline Abs(Dif)-LSD & TCP & $\mathbf{1 2 0} \mathbf{~ m g / m l}$ & Media & $\mathbf{8 0} \mathbf{~} \mathbf{g} / \mathbf{m l}$ & $\mathbf{6 0} \mathbf{~} \mathbf{g} / \mathbf{m l}$ & $\mathbf{1 4 0} \mathbf{~} \mathbf{g} / \mathbf{m l}$ & $\mathbf{1 0 0} \mathbf{~} \mathbf{g} / \mathbf{m l}$ \\
\hline TCP & -32.505 & -28.787 & -35.204 & -13.747 & -13.405 & -13.104 & -8.029 \\
\hline $120 \mathrm{mg} / \mathrm{ml}$ & -28.787 & -32.505 & -38.922 & -17.465 & -17.123 & -16.822 & -11.747 \\
\hline Media & -35.204 & -38.922 & -56.301 & -37.977 & -37.635 & -37.333 & -32.258 \\
\hline $80 \mathrm{mg} / \mathrm{ml}$ & -13.747 & -17.465 & -37.977 & -32.505 & -32.163 & -31.862 & -26.787 \\
\hline $60 \mathrm{mg} / \mathrm{ml}$ & -13.405 & -17.123 & -37.635 & -32.163 & -32.505 & -32.204 & -27.129 \\
\hline $140 \mathrm{mg} / \mathrm{ml}$ & -13.104 & -16.822 & -37.333 & -31.862 & -32.204 & -32.505 & -27.430 \\
\hline $100 \mathrm{mg} / \mathrm{ml}$ & -8.029 & -11.747 & -32.258 & -26.787 & -27.129 & -27.430 & -32.505 \\
\hline
\end{tabular}

Positive values show pairs of means that are significantly different.

$\begin{array}{llr}\text { Level } & & \text { Mean } \\ \text { TCP } & \text { A } & 36.930333 \\ 120 \mathrm{mg} / \mathrm{ml} & \text { A } & 33.212000 \\ \text { Media } & \text { A } & 26.165000 \\ 80 \mathrm{mg} / \mathrm{ml} & \text { A } & 18.172333 \\ 60 \mathrm{mg} / \mathrm{ml} & \text { A } & 17.830333 \\ 140 \mathrm{mg} / \mathrm{ml} & \text { A } & 17.529000 \\ 100 \mathrm{mg} / \mathrm{ml} & \text { A } & 12.454000\end{array}$

Levels not connected by same letter are significantly different.

$\begin{array}{llrr}\text { Level } & - \text { Level } & \text { Difference } & \text { Lower CL } \\ \mathrm{TCP} & 100 \mathrm{mg} / \mathrm{ml} & 24.47633 & -8.0288 \\ 120 \mathrm{mg} / \mathrm{ml} & 100 \mathrm{mg} / \mathrm{ml} & 20.75800 & -11.7471 \\ \mathrm{TCP} & 140 \mathrm{mg} / \mathrm{ml} & 19.40133 & -13.1038 \\ \mathrm{TCP} & 60 \mathrm{mg} / \mathrm{ml} & 19.10000 & -13.4051 \\ \mathrm{TCP} & 80 \mathrm{mg} / \mathrm{ml} & 18.75800 & -13.7471 \\ 120 \mathrm{mg} / \mathrm{ml} & 140 \mathrm{mg} / \mathrm{ml} & 15.68300 & -16.8221 \\ 120 \mathrm{mg} / \mathrm{ml} & 60 \mathrm{mg} / \mathrm{ml} & 15.38167 & -17.1234 \\ 120 \mathrm{mg} / \mathrm{ml} & 80 \mathrm{mg} / \mathrm{ml} & 15.03967 & -17.4654 \\ \text { Media } & 100 \mathrm{mg} / \mathrm{ml} & 13.71100 & -32.2582 \\ \mathrm{TCP} & \mathrm{Media} & 10.76533 & -35.2038 \\ \text { Media } & 140 \mathrm{mg} / \mathrm{ml} & 8.63600 & -37.3332 \\ \text { Media } & 60 \mathrm{mg} / \mathrm{ml} & 8.33467 & -37.6345 \\ \mathrm{Media} & 80 \mathrm{mg} / \mathrm{ml} & 7.99267 & -37.9765 \\ 120 \mathrm{mg} / \mathrm{ml} & \mathrm{Media} & 7.04700 & -38.9222 \\ 80 \mathrm{mg} / \mathrm{ml} & 100 \mathrm{mg} / \mathrm{ml} & 5.71833 & -26.7868 \\ 60 \mathrm{mg} / \mathrm{ml} & 100 \mathrm{mg} / \mathrm{ml} & 5.37633 & -27.1288 \\ 140 \mathrm{mg} / \mathrm{ml} & 100 \mathrm{mg} / \mathrm{ml} & 5.07500 & -27.4301 \\ \mathrm{TCP} & 120 \mathrm{mg} / \mathrm{ml} & 3.71833 & -28.7868 \\ 80 \mathrm{mg} / \mathrm{ml} & 140 \mathrm{mg} / \mathrm{ml} & 0.64333 & -31.8618 \\ 80 \mathrm{mg} / \mathrm{ml} & 60 \mathrm{mg} / \mathrm{ml} & 0.34200 & -32.1631 \\ 60 \mathrm{mg} / \mathrm{ml} & 140 \mathrm{mg} / \mathrm{ml} & 0.30133 & -32.2038\end{array}$

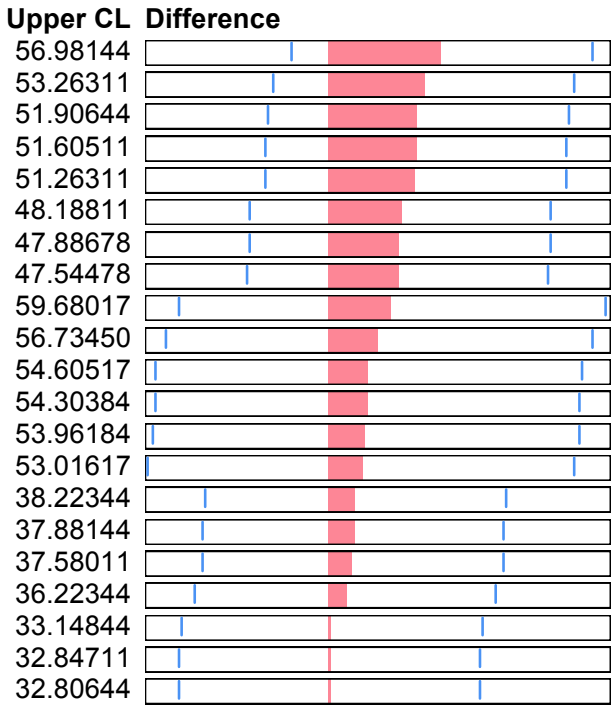


Oneway Analysis of Day 14 By PDO scaffolds of varying concentration for TGF- $\beta 1$ secretion

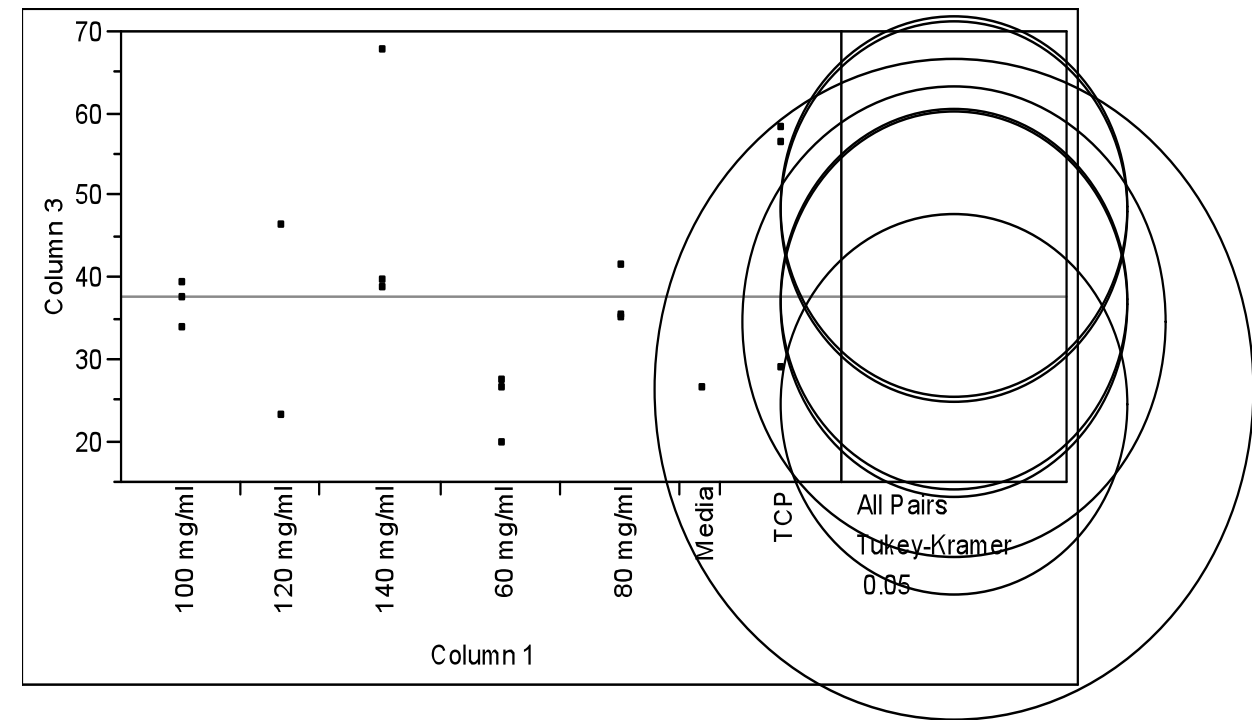

Missing Rows

1

Means Comparisons

Comparisons for all pairs using Tukey-Kramer HSD

3.55539

Alpha

0.05

\begin{tabular}{|l|r|r|r|r|r|r|r|}
\hline Abs(Dif)-LSD & $\mathbf{1 4 0} \mathbf{~} \mathbf{g} / \mathbf{m l}$ & TCP & $\mathbf{8 0} \mathbf{~} \mathbf{g} / \mathbf{m l}$ & $\mathbf{1 0 0} \mathbf{~} \mathbf{g} / \mathbf{m l}$ & $\mathbf{1 2 0} \mathbf{~} \mathbf{g} / \mathbf{m l}$ & Media & $\mathbf{6 0} \mathbf{~} \mathbf{g} / \mathbf{m l}$ \\
\hline $140 \mathbf{~ m g} / \mathbf{m l}$ & -33.133 & -32.351 & -21.775 & -21.320 & -22.955 & -24.467 & -8.921 \\
\hline TCP & -32.351 & -33.133 & -22.557 & -22.102 & -23.737 & -25.249 & -9.702 \\
\hline $80 \mathbf{~ m g} / \mathrm{ml}$ & -21.775 & -22.557 & -33.133 & -32.678 & -34.312 & -35.824 & -20.278 \\
\hline $100 \mathbf{~ m g} / \mathrm{ml}$ & -21.320 & -22.102 & -32.678 & -33.133 & -34.767 & -36.279 & -20.733 \\
\hline $120 \mathbf{~ m g} / \mathrm{ml}$ & -22.955 & -23.737 & -34.312 & -34.767 & -40.579 & -41.398 & -26.920 \\
\hline Media & -24.467 & -25.249 & -35.824 & -36.279 & -41.398 & -57.388 & -45.034 \\
\hline $60 \mathbf{m g} / \mathrm{ml}$ & -8.921 & -9.702 & -20.278 & -20.733 & -26.920 & -45.034 & -33.133 \\
\hline
\end{tabular}

Positive values show pairs of means that are significantly different.

$\begin{array}{llr}\text { Level } & & \text { Mean } \\ 140 \mathrm{mg} / \mathrm{ml} & \text { A } & 48.554667 \\ \mathrm{TCP} & \text { A } & 47.773000 \\ 80 \mathrm{mg} / \mathrm{ml} & \text { A } & 37.197333 \\ 100 \mathrm{mg} / \mathrm{ml} & \text { A } & 36.742333 \\ 120 \mathrm{mg} / \mathrm{ml} & \text { A } & 34.466000 \\ \text { Media } & \text { A } & 26.165000 \\ 60 \mathrm{mg} / \mathrm{ml} & \text { A } & 24.342667\end{array}$

Levels not connected by same letter are significantly different.

$\begin{array}{llrr}\text { Level } & - \text { Level } & \text { Difference } & \text { Lower CL } \\ 140 \mathrm{mg} / \mathrm{ml} & 60 \mathrm{mg} / \mathrm{ml} & 24.21200 & -8.9207 \\ \mathrm{TCP} & 60 \mathrm{mg} / \mathrm{ml} & 23.43033 & -9.7024 \\ 140 \mathrm{mg} / \mathrm{ml} & \text { Media } & 22.38967 & -24.4671 \\ \mathrm{TCP} & \text { Media } & 21.60800 & -25.2487 \\ 140 \mathrm{mg} / \mathrm{ml} & 120 \mathrm{mg} / \mathrm{ml} & 14.08867 & -22.9548 \\ \mathrm{TCP} & 120 \mathrm{mg} / \mathrm{ml} & 13.30700 & -23.7365 \\ 80 \mathrm{mg} / \mathrm{ml} & 60 \mathrm{mg} / \mathrm{ml} & 12.85467 & -20.2781\end{array}$

\begin{tabular}{|c|c|}
\hline Upper CL & Diff \\
\hline 57.34473 & 1 \\
\hline 56.56306 & 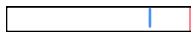 \\
\hline 69.24642 & T \\
\hline 68.46475 & \\
\hline 51.13218 & $T$ \\
\hline 50.35051 & $T$ \\
\hline 45.98739 & 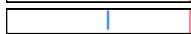 \\
\hline
\end{tabular}




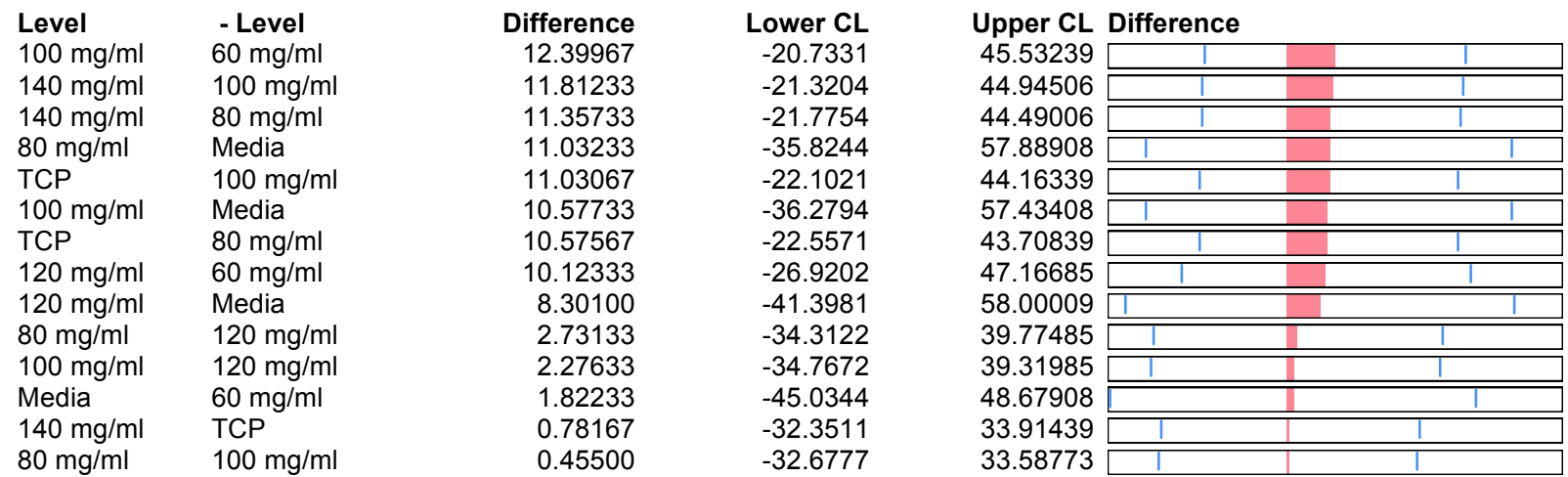

\section{Oneway Analysis of Day 21 By PDO scaffolds of varying concentration for TGF- $\beta 1$ secretion}

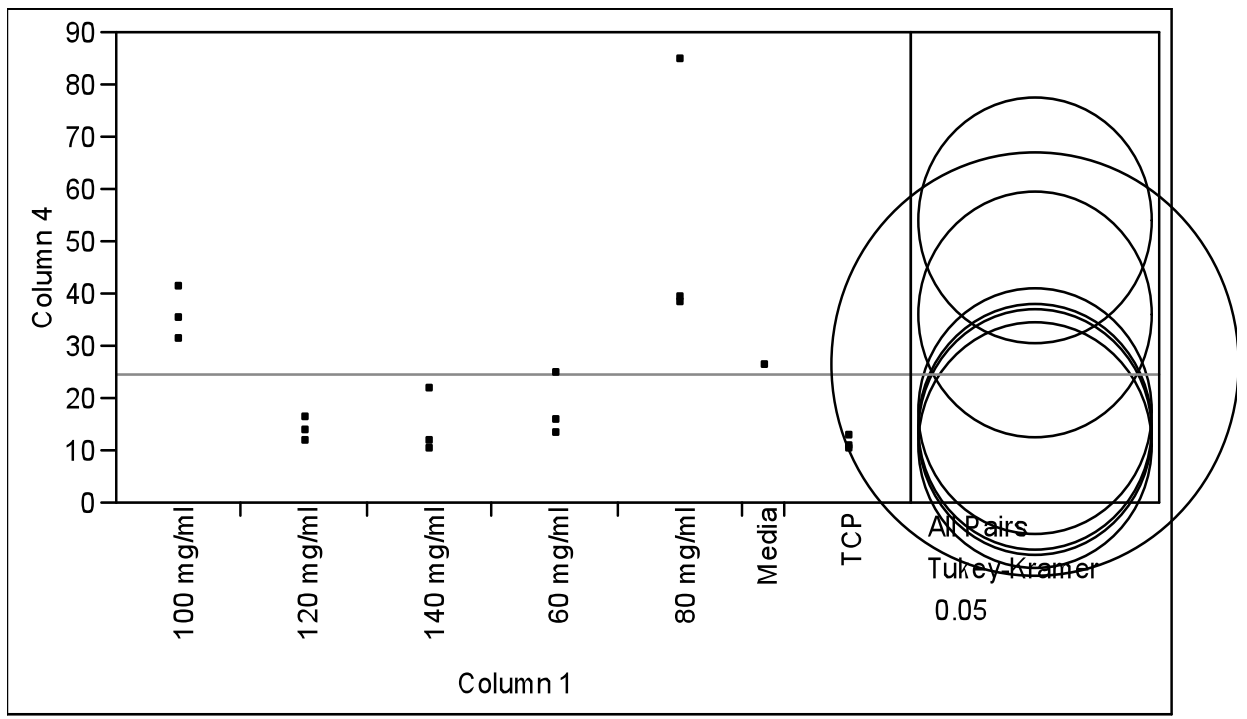

\section{Means Comparisons \\ Comparisons for all pairs using Tukey-Kramer HSD

$\begin{array}{rr}\mathbf{q}^{*} & \text { Alpha } \\ 3.49978 & 0.05\end{array}$

\begin{tabular}{|l|r|r|r|r|r|r|r|}
\hline Abs(Dif)-LSD & $\mathbf{8 0} \mathbf{~} \mathbf{~ g} / \mathbf{m l}$ & $\mathbf{1 0 0} \mathbf{~} \mathbf{g} / \mathbf{m l}$ & Media & $\mathbf{6 0} \mathbf{~} \mathbf{g} / \mathbf{m l}$ & $\mathbf{1 4 0} \mathbf{~} \mathbf{g} / \mathbf{m l}$ & $\mathbf{1 2 0} \mathbf{~} \mathbf{g} / \mathbf{m l}$ & TCP \\
\hline $80 \mathbf{~ m g} / \mathrm{ml}$ & -33.333 & -15.219 & -19.427 & 2.962 & 6.130 & 7.105 & 9.451 \\
\hline $100 \mathbf{m g} / \mathrm{ml}$ & -15.219 & -33.333 & -37.540 & -15.152 & -11.983 & -11.008 & -8.663 \\
\hline Media & -19.427 & -37.540 & -57.734 & -38.558 & -35.390 & -34.415 & -32.069 \\
\hline $60 \mathbf{~ m g} / \mathrm{ml}$ & 2.962 & -15.152 & -38.558 & -33.333 & -30.164 & -29.189 & -26.844 \\
\hline $140 \mathbf{m g} / \mathrm{ml}$ & 6.130 & -11.983 & -35.390 & -30.164 & -33.333 & -32.358 & -30.012 \\
\hline $120 \mathbf{~ m g} / \mathrm{ml}$ & 7.105 & -11.008 & -34.415 & -29.189 & -32.358 & -33.333 & -30.987 \\
\hline TCP & 9.451 & -8.663 & -32.069 & -26.844 & -30.012 & -30.987 & -33.333 \\
\hline
\end{tabular}

Positive values show pairs of means that are significantly different.

Level

$80 \mathrm{mg} / \mathrm{ml}$

$100 \mathrm{mg} / \mathrm{ml}$

Media
Mean
$\begin{array}{lll}\text { A } & & 53.878000 \\ \text { A } & \text { B } & 35.764667\end{array}$
A $\mathrm{B} \quad 26.165000$ 


$\begin{array}{llr}\text { Level } & & \text { Mean } \\ 60 \mathrm{mg} / \mathrm{ml} & \mathrm{B} & 17.583667 \\ 140 \mathrm{mg} / \mathrm{ml} & \mathrm{B} & 14.415000 \\ 120 \mathrm{mg} / \mathrm{ml} & \mathrm{B} & 13.440000 \\ \mathrm{TCP} & \mathrm{B} & 11.094667\end{array}$

Levels not connected by same letter are significantly different.

$\begin{array}{ll}\text { Level } & \text { - Level } \\ 80 \mathrm{mg} / \mathrm{ml} & \text { TCP } \\ 80 \mathrm{mg} / \mathrm{ml} & 120 \mathrm{mg} / \mathrm{ml} \\ 80 \mathrm{mg} / \mathrm{ml} & 140 \mathrm{mg} / \mathrm{ml} \\ 80 \mathrm{mg} / \mathrm{ml} & 60 \mathrm{mg} / \mathrm{ml} \\ 80 \mathrm{mg} / \mathrm{ml} & \text { Media } \\ 100 \mathrm{mg} / \mathrm{ml} & \text { TCP } \\ 100 \mathrm{mg} / \mathrm{ml} & 120 \mathrm{mg} / \mathrm{ml} \\ 100 \mathrm{mg} / \mathrm{ml} & 140 \mathrm{mg} / \mathrm{ml} \\ 100 \mathrm{mg} / \mathrm{ml} & 60 \mathrm{mg} / \mathrm{ml} \\ 80 \mathrm{mg} / \mathrm{ml} & 100 \mathrm{mg} / \mathrm{ml} \\ \text { Media } & \text { TCP } \\ \text { Media } & 120 \mathrm{mg} / \mathrm{ml} \\ \text { Media } & 140 \mathrm{mg} / \mathrm{ml} \\ 100 \mathrm{mg} / \mathrm{ml} & \text { Media } \\ \text { Media } & 60 \mathrm{mg} / \mathrm{ml} \\ 60 \mathrm{mg} / \mathrm{ml} & \text { TCP } \\ 60 \mathrm{mg} / \mathrm{ml} & 120 \mathrm{mg} / \mathrm{ml} \\ 140 \mathrm{mg} / \mathrm{ml} & \text { TCP } \\ 60 \mathrm{mg} / \mathrm{ml} & 140 \mathrm{mg} / \mathrm{ml} \\ 120 \mathrm{mg} / \mathrm{ml} & \text { TCP } \\ 140 \mathrm{mg} / \mathrm{ml} & 120 \mathrm{mg} / \mathrm{ml}\end{array}$

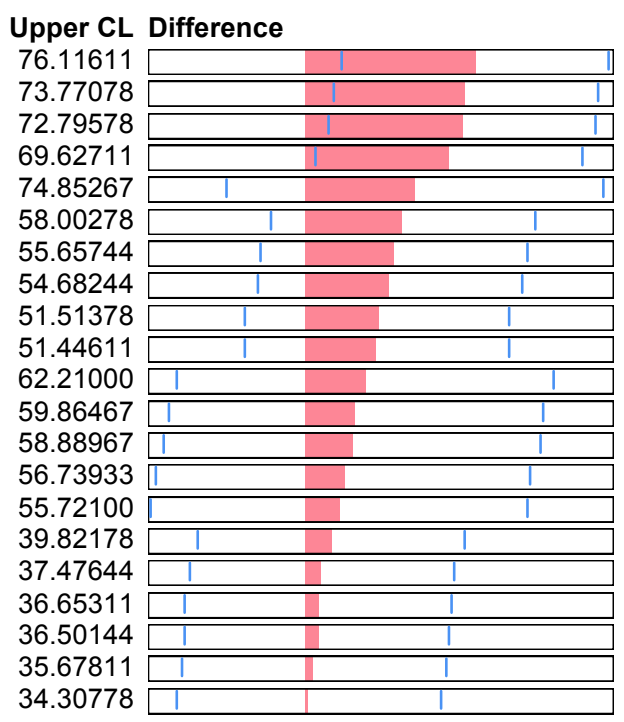

\section{Oneway Analysis of Day 28 By PDO scaffolds of varying concentration for TGF- $\beta 1$ secretion}

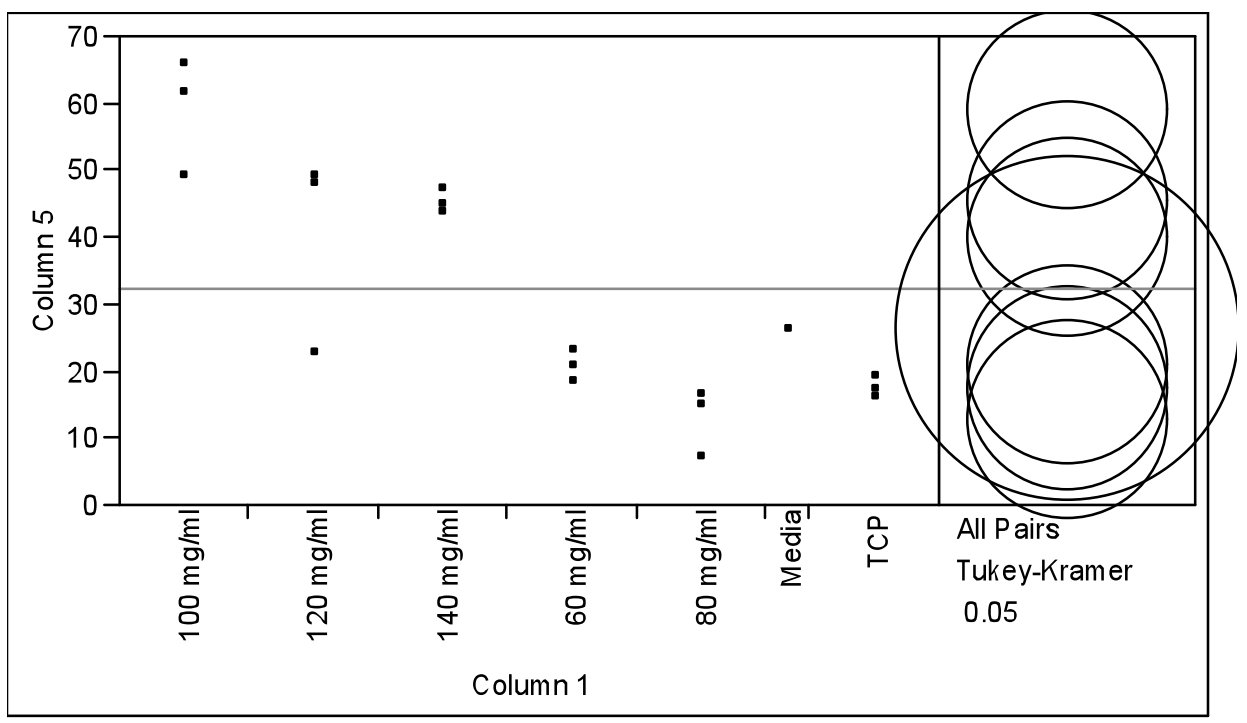

\section{Means Comparisons}

Comparisons for all pairs using Tukey-Kramer HSD

$\begin{array}{rr}\mathbf{q}^{*} & \text { Alpha } \\ 3.49978 & 0.05\end{array}$

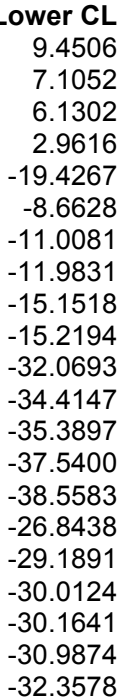




\begin{tabular}{|l|r|r|r|r|r|r|r|}
\hline Abs(Dif)-LSD & $\mathbf{1 0 0} \mathbf{~} \mathbf{g} / \mathbf{m l}$ & $\mathbf{1 4 0} \mathbf{~} \mathbf{g} / \mathbf{m l}$ & $\mathbf{1 2 0} \mathbf{~} \mathbf{g} / \mathbf{m l}$ & Media & $\mathbf{6 0} \mathbf{~} \mathbf{g} / \mathbf{m l}$ & TCP & $\mathbf{8 0} \mathbf{~} \mathbf{g} / \mathbf{m l}$ \\
\hline $100 \mathbf{~ m g} / \mathrm{ml}$ & -21.200 & -7.652 & -2.310 & 2.596 & 16.889 & 20.056 & 24.735 \\
\hline $140 \mathbf{~ m g} / \mathrm{ml}$ & -7.652 & -21.200 & -15.859 & -10.952 & 3.340 & 6.507 & 11.187 \\
\hline $120 \mathbf{~ m g} / \mathrm{ml}$ & -2.310 & -15.859 & -21.200 & -16.294 & -2.001 & 1.166 & 5.845 \\
\hline Media & 2.596 & -10.952 & -16.294 & -36.720 & -24.471 & -21.304 & -16.625 \\
\hline $60 \mathbf{~ m g} / \mathrm{ml}$ & 16.889 & 3.340 & -2.001 & -24.471 & -21.200 & -18.033 & -13.354 \\
\hline $\mathrm{TCP}$ & 20.056 & 6.507 & 1.166 & -21.304 & -18.033 & -21.200 & -16.521 \\
\hline $80 \mathrm{mg} / \mathrm{ml}$ & 24.735 & 11.187 & 5.845 & -16.625 & -13.354 & -16.521 & -21.200 \\
\hline
\end{tabular}

Positive values show pairs of means that are significantly different.

$\begin{array}{lllllr}\text { Level } & & & & & \text { Mean } \\ 100 \mathrm{mg} / \mathrm{ml} & \text { A } & & & & 58.743333 \\ 140 \mathrm{mg} / \mathrm{ml} & \text { A } & \text { B } & & & 45.194667 \\ 120 \mathrm{mg} / \mathrm{ml} & \text { A } & \text { B } & \text { C } & & 39.853333 \\ \text { Media } & & \text { B } & \text { C } & \text { D } & 26.165000 \\ 60 \mathrm{mg} / \mathrm{ml} & & & \text { C } & \text { D } & 20.654000 \\ \text { TCP } & & & & \text { D } & 17.487000 \\ 80 \mathrm{mg} / \mathrm{ml} & & & & \text { D } & 12.807667\end{array}$

Levels not connected by same letter are significantly different.

$\begin{array}{llrr}\text { Level } & \text { - Level } & \text { Difference } & \text { Lower CL } \\ 100 \mathrm{mg} / \mathrm{ml} & 80 \mathrm{mg} / \mathrm{ml} & 45.93567 & 24.7352 \\ 100 \mathrm{mg} / \mathrm{ml} & \text { TCP } & 41.25633 & 20.0559 \\ 100 \mathrm{mg} / \mathrm{ml} & 60 \mathrm{mg} / \mathrm{ml} & 38.08933 & 16.8889 \\ 100 \mathrm{mg} / \mathrm{ml} & \text { Media } & 32.57833 & 2.5964 \\ 140 \mathrm{mg} / \mathrm{ml} & 80 \mathrm{mg} / \mathrm{ml} & 32.38700 & 11.1865 \\ 140 \mathrm{mg} / \mathrm{ml} & \text { TCP } & 27.70767 & 6.5072 \\ 120 \mathrm{mg} / \mathrm{ml} & 80 \mathrm{mg} / \mathrm{ml} & 27.04567 & 5.8452 \\ 140 \mathrm{mg} / \mathrm{ml} & 60 \mathrm{mg} / \mathrm{ml} & 24.54067 & 3.3402 \\ 120 \mathrm{mg} / \mathrm{ml} & \text { TCP } & 22.36633 & 1.1659 \\ 120 \mathrm{mg} / \mathrm{ml} & 60 \mathrm{mg} / \mathrm{ml} & 19.19933 & -2.0011 \\ 140 \mathrm{mg} / \mathrm{ml} & \text { Media } & 19.02967 & -10.9523 \\ 100 \mathrm{mg} / \mathrm{ml} & 120 \mathrm{mg} / \mathrm{ml} & 18.89000 & -2.3105 \\ 120 \mathrm{mg} / \mathrm{ml} & \text { Media } & 13.68833 & -16.2936 \\ 100 \mathrm{mg} / \mathrm{ml} & 140 \mathrm{mg} / \mathrm{ml} & 13.54867 & -7.6518 \\ \mathrm{Media} & 80 \mathrm{mg} / \mathrm{ml} & 13.35733 & -16.6246 \\ \mathrm{Media} & \mathrm{TCP} & 8.67800 & -21.3040 \\ 60 \mathrm{mg} / \mathrm{ml} & 80 \mathrm{mg} / \mathrm{ml} & 7.84633 & -13.3541 \\ \mathrm{Media} & 60 \mathrm{mg} / \mathrm{ml} & 5.51100 & -24.4710 \\ 140 \mathrm{mg} / \mathrm{ml} & 120 \mathrm{mg} / \mathrm{ml} & 5.34133 & -15.8591 \\ \mathrm{TCP} & 80 \mathrm{mg} / \mathrm{ml} & 4.67933 & -16.5211 \\ 60 \mathrm{mg} / \mathrm{ml} & \mathrm{TCP} & 3.16700 & -18.0335\end{array}$

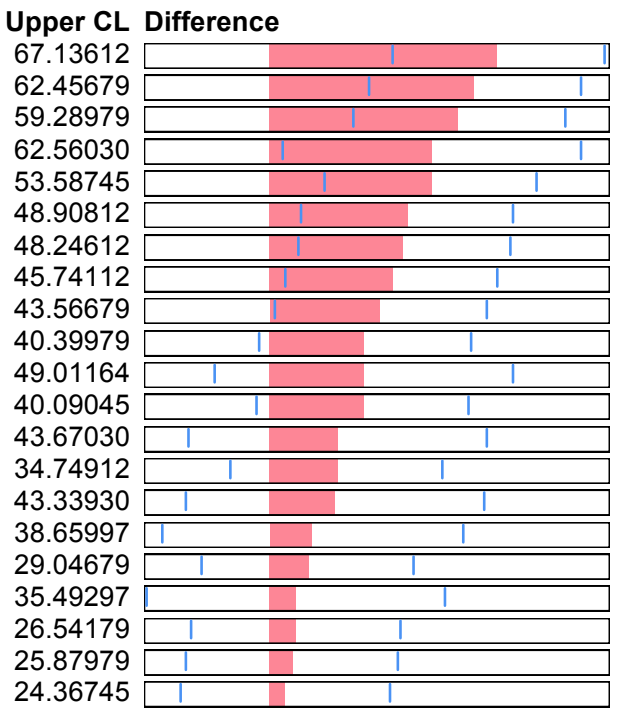




\section{$\underline{\text { VITA }}$}

Koyal Garg was born in Meerut, U.P., India on $29^{\text {th }}$ September 1985. She received a Bachelors of Engineering degree in Biomedical Instrumentation Engineering from Avinashilingam Deemed University, India in May 2006. In fall of 2006, she started graduate studies in Virginia Commonwealth University in Biomedical Engineering. She is a member of the Virginia Commonwealth University chapter of the Alpha Eta Mu Beta Biomedical Engineering Honor Society and the Biomedical Engineering Society (BMES). She has presented posters at various conferences including Annual Hilton Head

Workshop, BMES annual fall meeting and The International Society for Applied Cardiovascular Biology (ISACB) Biennial meeting. She had also worked as a Teaching Assistant for several courses, such as Biomedical Instrumentation, Computational Methods and Biomedical Signal Processing. 